\author{
UNIVERSIDADE DE SÃO PAULO \\ FACULDADE DE ECONOMIA, ADMINISTRAÇÃO E CONTABILIDADE \\ DE RIBEIRÃO PRETO \\ DEPARTAMENTO DE ADMINISTRAÇÃO
}

GLAUCO MATEUS MAGRINI CALDO

Resíduos de serviços de saúde (RSS): estudo multicaso comparativo do gerenciamento em organizações municipais pública, privada e mista, diante da pluralidade normativa

Orientadora: Profa. Dra. Sonia Valle Walter Borges de Oliveira

Ribeirão Preto 
Prof $^{\mathrm{a}}$. Dr ${ }^{\mathrm{a}}$. Suely Vilela

Reitora da Universidade de São Paulo

Prof. Dr. Rudinei Toneto Júnior

Diretor da Faculdade de Economia, Administração e Contabilidade de Ribeirão Preto

Prof. Dr. André Lucirton Costa

Chefe do Departamento de Administração 
GLAUCO MATEUS MAGRINI CALDO

Resíduos de serviços de saúde (RSS): estudo multicaso comparativo do gerenciamento em organizações municipais pública, privada e mista, diante da pluralidade normativa

Dissertação apresentada ao Programa de Pós-Graduação em Administração das Organizações da Faculdade de Economia, Administração e Contabilidade de Ribeirão Preto da Universidade de São Paulo, como requisito para obtenção do Título de Mestre em Administração das Organizações.

Orientadora: Profa. Dra. Sonia Valle Walter Borges de Oliveira

Ribeirão Preto 
Caldo, Glauco Mateus Magrini.

Resíduos de serviços de saúde (RSS): estudo multicaso comparativo do gerenciamento em organizações municipais pública, privada e mista, diante da pluralidade normativa. Ribeirão Preto (2009).

181 p. : il. ; $30 \mathrm{~cm}$

Dissertação de Mestrado, apresentada à Faculdade de Economia, Administração e Contabilidade de Ribeirão Preto da Universidade de São Paulo.

Orientador: Oliveira, Sonia Valle Walter Borges de

1. Resíduos de Serviços de Saúde. 2. Estudo multicaso. 3. Pluralidade normativa. 


\section{FOLHA DE APROVAÇÃO}

\section{Glauco Mateus Magrini Caldo}

Resíduos de serviços de saúde (RSS): estudo multicaso comparativo do gerenciamento em organizações municipais pública, privada e mista, diante da pluralidade normativa

Aprovado em:

Dissertação apresentada ao Programa de Pós-Graduação em Administração de Organizações da Faculdade de Economia, Administração e Contabilidade de Ribeirão Preto da Universidade de São Paulo como requisito para obtenção do título de Mestre em Administração.

\section{Banca examinadora}

Nome:

Instituição: Assinatura:

Nome:

Instituição: Assinatura:

Nome:

Instituição: Assinatura: 


\title{
HOMENAGEM PÓSTUMA
}

\author{
IN MEMORIAM \\ de \\ RAPHAEL MATHEUS CALDO
}

$(1926-2007)$

Se cheguei até aqui hoje, muito, mas muito mesmo, se deve ao senhor: pessoa doce e gentil, marido dedicado, trabalhador incansável, tio-avô extremamente bondoso, carinhoso, paciente e amigo (muito mais avô do que tio), um verdadeiro anjo-da-guarda, um pai que qualquer um teria orgulho de ter, que partiu serena e repentinamente, sem que eu pudesse ter a chance de agradecer por tudo o que o senhor foi e significou na minha vida.

Obrigado por sua presença sempre constante, bem como por seus ensinamentos, seu caráter e seus valores! Obrigado por sua bondade! Obrigado por todo o seu amor! Que o senhor hoje esteja ocupando seu lugar junto a Deus, e olhando por nós aqui na terra! 


\section{DEDICATÓRIAS}

Dedico este trabalho:

Ao meu filho IGOR SCRIPNIC CALDO, luz da minha vida e razão da minha existência, uma criaturinha que resolveu se adiantar e chegou de repente, sem pedir licença, mas acabou ocupando um espaço até então desconhecido dentro da minha alma e do meu coração. Minha criança, meu moleque, meu menininho, meu professor: nossa convivência diária me encanta, suas palavrinhas me iluminam e você me faz passar da condição de pai à condição de filho, da condição de mestre à condição de aprendiz. Papai te ama! Esta obra é pra você!

À minha amorosa esposa PATRÍCIA SCRIPNIC CALDO, por todas as horas de convivência roubadas na frente de um terminal de computador, as quais foram necessárias para a conclusão desta dissertação. Sem o seu apoio, dificilmente eu conseguiria.

Aos meus cães SANSÃO e DALILA, pelas brincadeiras adiadas e passeios não realizados com seu dono, também devido ao tempo dedicado para confecção do presente trabalho. 


\section{AGRADECIMENTOS}

À minha Orientadora, Professora Doutora SONIA VALLE WALTER BORGES DE OLIVEIRA, por toda a atenção e interesse demonstrados na orientação e realização do presente trabalho. A inteligência de suas colocações, seu didatismo e sua paciência ímpar, seja como Professora, seja como Orientadora ou simplesmente Amiga, contribuíram definitivamente não só para a conclusão desta dissertação, como também e decisivamente, para a minha formação como aluno, pesquisador e ser humano.

Ao Professor Doutor VALDIR SCHALCH, que, gentilmente, aceitou o convite para fazer parte de minha Banca Examinadora, mesmo em detrimento de suas excessivas e constantes ocupações. Os ensinamentos presentes em todas as suas aulas muito contribuíram para a elaboração desta dissertação.

Ao Professor Doutor ANDRÉ LUCIRTON COSTA, por aceitar compor a Banca Examinadora e contribuir, com suas ponderações, para a correção, revisão e término do presente trabalho.

À Gerente do Departamento de Resíduos da Secretaria Municipal da Saúde, Doutora MARLENE DUARTE MENDES, por todas as informações úteis e relevantes prestadas para este mestrando, além de toda a solicitude demonstrada e das dicas altruístas fornecidas, muitas delas imprescindíveis para a conclusão desta dissertação.

À MARIA CRISTINA FERRARI DE ALMEIDA, Diretora de Serviço do Fórum Estadual de Ribeirão Preto, vinculado ao Tribunal de Justiça do Estado de São Paulo, por toda a colaboração e compreensão para com este mestrando, na qualidade de sua chefe imediata, no que se referiu às suas necessárias ausências do serviço para participação nas aulas e outras atividades do Curso de Mestrado.

À MARIA EMÍLIA DE SOUZA AGOSTINI, Oficial Maior do Fórum Estadual de Ribeirão Preto, vinculado ao Tribunal de Justiça do Estado de São Paulo, pela colaboração e compreensão para com este mestrando, no que tangeu às suas ausências e necessidades de horários especiais de trabalho, sem as quais não teria sido possível concluir este Curso de Mestrado.

Aos Professores Doutores ANGELA MARIA MAGOSSO TAKAYANAGUI e CARLOS ALBERTO GABRIELLI BARRETO CAMPELLO, pela participação na suplência da presente Banca Examinadora.

A todos os GESTORES, DIRETORES, GERENTES e FUNCIONÁRIOS das instituições pesquisadas, que contribuíram com suas entrevistas para a coleta de dados e conseqüente conclusão desta dissertação, bem como que de pronto autorizaram a divulgação de seus dados e informações na confecção da presente.

Finalmente, aos COLEGAS DE CLASSE, aos AMIGOS EXTRA-CLASSE e a TODOS que, de uma maneira geral, contribuíram para a realização deste trabalho. 
"Chegará o dia em que os homens conhecerão o íntimo dos animais, e, neste dia, um crime contra um animal será considerado um crime contra a humanidade".

Leonardo da Vinci (1452-1519) 


\section{RESUMO}

CALDO, G.M.M. Resíduos de Serviços de Saúde (RSS): Estudo Multicaso Comparativo do Gerenciamento em Organizações Municipais Pública, Privada e Mista, Diante da Pluralidade Normativa. 2009. 145 f. Dissertação (Mestrado em Administração das Organizações)-Faculdade de Economia, Administração e Contabilidade de Ribeirão Preto - FEARP, Universidade de São Paulo - USP, 2009.

É inegável que as questões relativas ao meio ambiente têm ocupado um espaço cada vez maior na agenda das sociedades humanas atuais, gerando novas implicações no âmbito político, econômico e social para todo tipo de organização. No Brasil, a ausência de uma legislação compilada de caráter ambiental, cumulada com a permissão dada a vários órgãos e entes jurídicos para emanarem atos administrativos versando sobre o tema, levando inclusive a conflitos normativos, acaba por gerar uma série de problemas, que constituem verdadeiros desafios para gestores que lidam com questões extremamente importantes para a coletividade, como o gerenciamento dos resíduos de serviços de saúde, conhecidos pela sigla RSS. Desta forma, ante as conhecidas diferenças que existem no modo de se administrar organizações públicas e privadas no país, o presente trabalho estudou comparativamente algumas delas (instituições públicas, privada e mista), atuantes todas na cidade de Ribeirão Preto, verificando o modo como cada uma gerencia os seus resíduos de serviços de saúde e constatando se as diferenças encontradas são ou não ocasionadas por interpretações distintas da legislação vigente, mensurando-se, assim, o grau de sucesso de cada uma e concluindo se os procedimentos adotados se enquadram, na prática, ao texto das normas que versam sobre a matéria. Na parte empírica, analisaram-se, como indicadores, as visões macro (gerência) e micro (operacional) relativamente ao gerenciamento dos resíduos de serviços de saúde, através de entrevistas realizadas com os gestores e funcionários responsáveis dentro das organizações pesquisadas, além de terem sido visitadas várias instalações para se acompanhar, na prática, parte de todo o processo operacional envolvendo o tema. Como fora realizado também um levantamento prévio de todas as normas relativas aos resíduos dos serviços de saúde, concluiu-se que as diferenças no gerenciamento se devem muito mais à natureza das organizações do que ao modo como os administradores aplicam as várias normas existentes no seu cotidiano de trabalho.

Palavras-chave: Resíduos de Serviços de Saúde. Gerenciamento de resíduos. Meio ambiente. Conflito normativo. Organizações de Saúde. 


\begin{abstract}
CALDO, G.M.M. Wastes From the Health Services (RSS): Varied Comparative Study of Municipal Management Organizations in Public, Private and Joint in Front of the Plurality Normative. 2009. 145 p. Dissertation (Master in Management of Organizations). Faculdade de Economia, Administração e Contabilidade de Ribeirão Preto - FEARP, Universidade de São Paulo - USP.
\end{abstract}

It is undeniable that the relative questions to the environment have busy a space each bigger time in the agenda of the societies current human beings, generating new implications in the scope politician, economic and social for all type of organization. In Brazil, absence of legislation compiled of character ambient, cumulated with permission given to some agencies and beings legal to emanate acts administrative turning on subject, leading also to conflicts normative, finishes for to generate series of problems, that they constitute true challenges for managers whom they extremely deal with important questions for the collective, as the management of the wastes from the health services, known by the acronym RSS. Thus, before the known differences that exist in order to manage public and private organizations in the country, this paper studied comparatively few of them (publics, institutions, private and mixed institutions), all working in the city of Ribeirão Preto, noting how each manages a wastes of their health services and noting whether the differences found or not they are caused by different interpretations of existing legislation, measuring, therefore, the degree of success of each and concluded that the procedures adopted fit in practice, the text of the rules that deal with the matter. At the empirical, analyzed, as indicators, the visions macro (management) and micro (operational) for the management of wastes from health services, through interviews with managers and responsible officials within the organizations surveyed, beyond having been visited some installations to be accompanied by, in the practical one, part of all the operational process involving the subject. As the relative norms to the residues of the health services are also carried through a previous survey of all, concluded that the differences in the management if must much more to the nature of the organizations of what to the way as the administrators apply some existing norms in its daily one of work.

Keywords: Wastes from the Health Services. Management of Residues. Environment. Normative Conflict. Health Organizations. 



\section{SUMÁRIO}

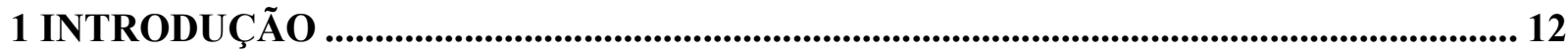

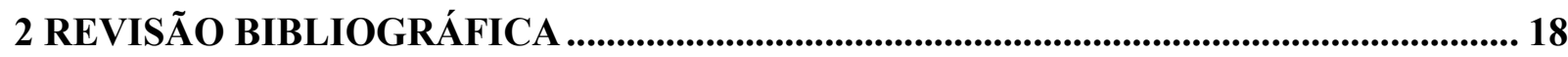

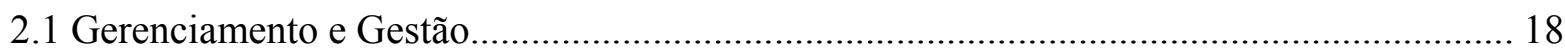

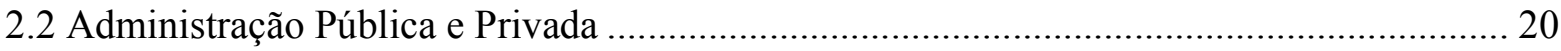

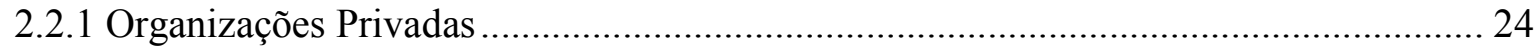

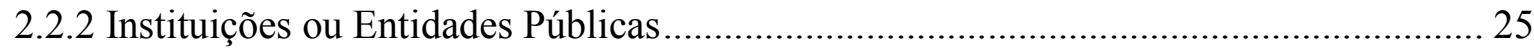

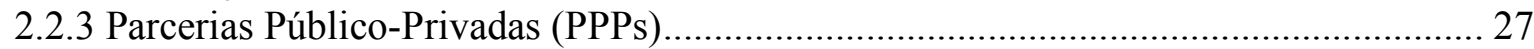

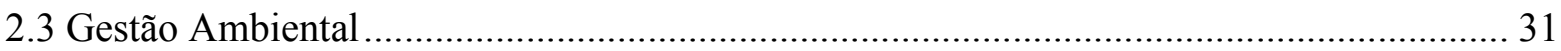

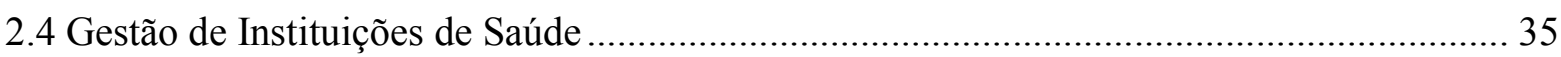

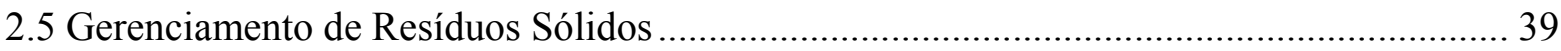

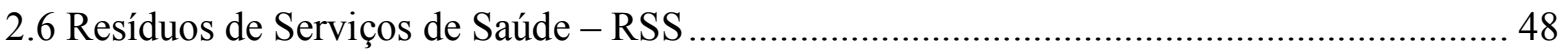

2.7 Legislação e Normatividade Relacionadas aos RSS .......................................................... 51

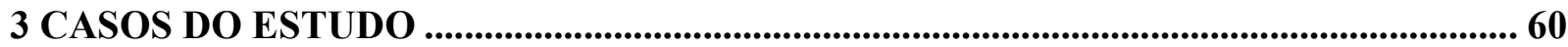

3.1 Unidade Básica Municipal de Saúde - UBDS “Dr João Baptista Quartin” - Central

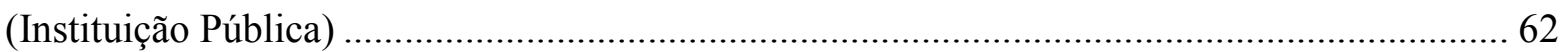

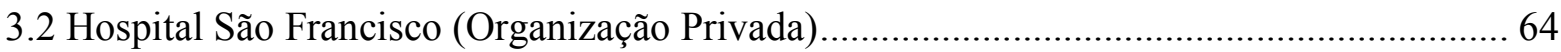

3.3 Hospital Sociedade Portuguesa de Beneficência (Fundação - Parceria Público-Privada) ... 66

3.4 Centro de Saúde Escola do Sumarezinho - UBDS “Joel Domingos Machado” (Parceria

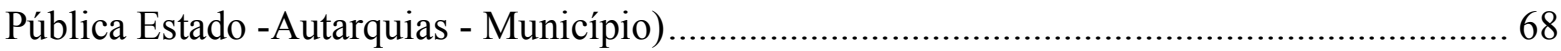

4 PROCEDIMENTOS METODOLÓGICOS ......................................................................... 72

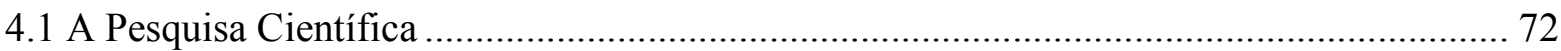

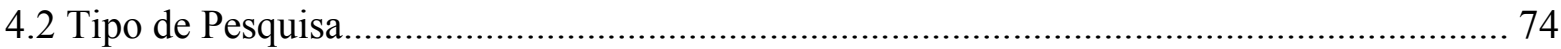

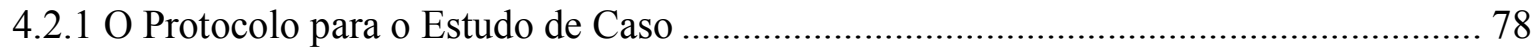

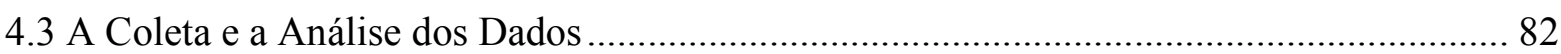

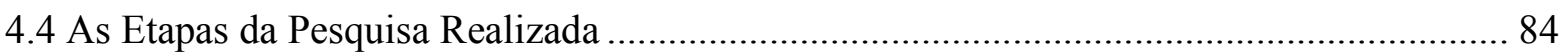

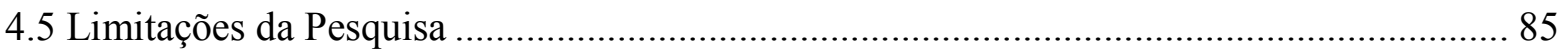

4.5.1 As Limitações Metodológicas Propriamente Ditas ..................................................... 85

4.5.2 Dificuldades da Coleta de Dados nas Organizações Pesquisadas ................................. 90

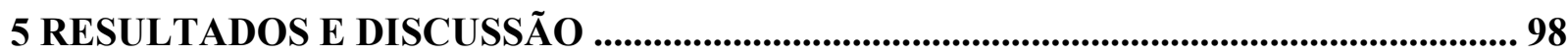

5.1 O Gerenciamento de Resíduos e a Fiscalização................................................................ 98

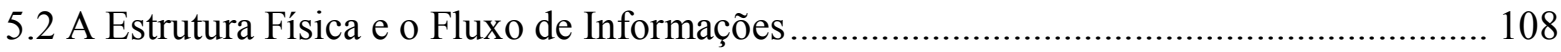

5.3 O Conhecimento Normativo e a Capacitação do Pessoal .................................................. 118

5.4 A Autonomia na Tomada de Decisões .......................................................................... 124

6 CONCLUSÃO

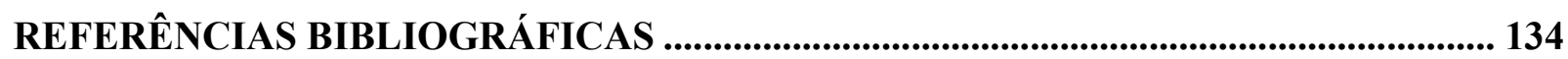




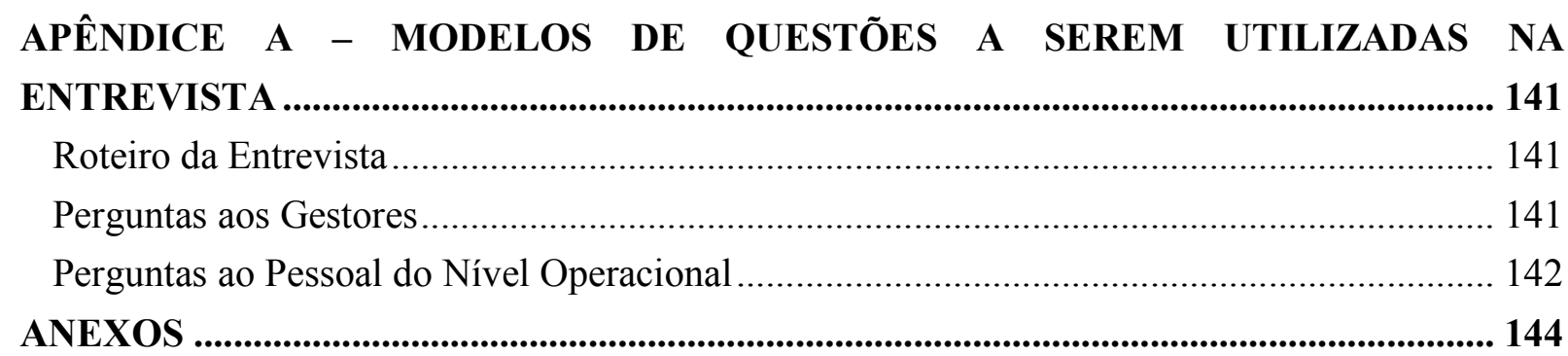




\section{INTRODUÇÃO}

\subsection{Considerações Iniciais e Justificativa do Tema}

Em que pese a variedade de conceitos que hoje são utilizados, pode-se dizer de maneira concisa que, relativamente ao seu significado, o termo meio ambiente relaciona-se a tudo aquilo que nos circunda, considerando-se aí que o pronome "nós", no sentido mais abrangente da palavra, engloba a própria sociedade humana.

Fiorillo (2008) entende que esta conceituação simplória merece ser criticada, por considerá-la pleonástica (gramaticalmente), eis que o termo ambiente já traria em seu conteúdo a idéia de "âmbito que circunda", daí o excesso de ser utilizado conjuntamente com a palavra meio.

De qualquer forma, a definição legal utiliza o termo meio ambiente, conforme dispõe o artigo $3^{\circ}$, inciso I, da Lei $n^{\circ}$ 6.938/81 (Lei da Política Nacional do Meio Ambiente):

Art. $3^{\circ}$ Para os fins previstos nesta Lei, entende-se por:

I - meio ambiente, o conjunto de condições, leis, influências e interações de ordem física, química e biológica, que permite, abriga e rege a vida em todas as suas formas. (BRASIL, 1981).

Por outro lado, as questões ambientais que englobam praticamente todas as relações do homem com o planeta ganharam destaque mundial nos últimos anos, em decorrência de problemas os mais variados que cada vez mais têm chamado a atenção para a sustentabilidade da vida humana (SACHS, 1993), colocando em xeque os atuais modelos social, econômico e industrial adotados globalmente após o fim da guerra fria.

Neste sentido, Benjamin (1995) pondera que a atual crise ambiental é fruto da própria revolução industrial, que, ao surgir, prometia a unidade universal, a paz e o bem estar para todos, mas jamais considerou os efeitos da produção e do consumo desenfreados que desencadearia nos séculos que se seguiram, junto ao meio ambiente. Por este motivo, a revolução industrial, na opinião do autor, teria deixado um débito ambiental que dificilmente a humanidade conseguirá resgatar, apesar do seu inegável legado de crescimento econômico e progresso tecnológico.

Seiffert (2007) considera que uma das causas dos atuais problemas ambientais que assolam a humanidade é o padrão de consumo adotado pelas populações, que a partir da revolução industrial foi se tornando cada vez mais exigente, sofisticado e esbanjador. Para a autora, este é um fator de desequilíbrio constante, que além de tornar cada vez mais 
insustentáveis os espaços urbanos, exige cada vez mais dos cada vez menores espaços rurais e dos limitados recursos naturais, num ciclo vicioso que, além de degradar o meio ambiente, ainda compromete a sustentabilidade humana nos seus aspectos material, econômico e social.

Com efeito, Derani (2007) considera que a natureza exerce dupla função na percepção humana, qual seja, além de lhe servir como fonte de produção e reprodução econômica, também lhe proporciona a sensação de bem estar. Por estes motivos, é praticamente impossível separar o ser humano da natureza, seja porque isso também impossibilitaria sua existência material, seja porque também prejudicaria seu equilíbrio psíquico.

Referida autora também entende que foi através da revolução industrial que esta relação homem-natureza começou a mudar, com a gradativa destruição da segunda, o que serviria para impulsionar, décadas mais tarde, as primeiras normas editadas com o objetivo de proteger e preservar os recursos naturais e o meio ambiente.

Para Soares (2001) o meio ambiente, como hoje é entendido e definido, isto é, compreendendo as relações entre a biosfera e seu meio circundante, em particular nos aspectos de solidariedade e integração entre os elementos que o compõem, somente passou a integrar o mundo jurídico como um valor autônomo a partir de meados do século passado.

Já no final do século XX, as questões ambientais começaram a imprimir seus reflexos no campo das ciências humanas aplicadas, como a administração, a economia e o direito, fazendo com que novos ramos destas ciências surgissem, como a gestão ambiental (no caso da administração), a eco-economia (no caso das ciências econômicas) e o direito ambiental (no caso das ciências jurídicas).

Atualmente, no Brasil, mesmo já havendo um grande conjunto de leis nos âmbitos federal, estadual e municipal relativas ao meio-ambiente - apesar de ainda não compiladas (OLIVEIRA, 1997) -, é comum ocorrer ainda, por parte das mais variadas entidades, autarquias e órgãos ligados à administração pública direta e indireta, a edição de normas, portarias, resoluções, decretos e outros atos administrativos sobre questões ligadas ao tema (algumas delas de difícil aplicação prática, ou conflitantes entre si), dificultando assim, sobremaneira, o cotidiano dos administradores que trabalham na área e, por vezes, até mesmo a tomada de decisões sobre questões operacionais simples do dia-a-dia.

Desta forma, os excessos normativos existentes, acrescidos de fatores como a competência concorrente dos entes federativos (união, estados e municípios) para legislar sobre o 
meio ambiente, bem como à natureza multidisciplinar desta própria legislação (existindo implicância ambiental nos mais diversos assuntos tratados pela lei) acaba por dificultar, sobremaneira, as tomadas de decisão por parte dos gestores e administradores das organizações diretamente envolvidas com os problemas reais oriundos destas questões.

É o que acontece, por exemplo, no caso das organizações geradoras de resíduos de serviços de saúde - conhecidos pela sigla RSS - cuja definição compreende desde bolsas de sangue, tecidos, órgãos e membros humanos, até medicamentos vencidos, hormônios sintéticos, reveladores e fixadores de raio $\mathrm{X}$, amálgama odontológico, agulhas luvas e seringas, materiais hospitalares contaminados com radionuclídeos, dentre outros; produzidos por organizações as mais variadas, tais como: hospitais, laboratórios, clínicas médicas e odontológicas, etc.

Outrossim, a Agência Nacional de Vigilância Sanitária (ANVISA), por meio da RDC 33/2003 (ANVISA, 2003), acrescentou e especificou novos serviços àqueles já previstos nas legislações anteriores, passando a incluir também: serviços de apoio à preservação da vida, indústrias, unidades de controle de zoonoses, serviços de tatuagem, serviços radiológicos, etc. Não bastasse, no ano seguinte, a ANVISA editou nova resolução de diretoria colegiada, a RDC 306, de 07 de dezembro de 2004 (ANVISA, 2004), que substituiu a RDC no 33/2003 no regulamento de técnicas, normas e procedimentos para o gerenciamento dos RSS.

Ocorre que, o que torna a tarefa do gestor mais inóspita, como já exposto, é o fato da ANVISA não ser o único órgão a legislar (ainda que tal vocábulo seja usado em seu sentido lato, isto é, no sentido de se editar normas, portarias, resoluções, decretos e outros) sobre RSS. Exemplo do acima exposto é a resolução no 05, de 05 de agosto de 1993 do Conselho Nacional do Meio Ambiente (CONAMA, 1993), a qual, dez anos antes da RDC 33 editada pela ANVISA, já dispunha sobre a definição, manejo, tratamento e disposição final dos resíduos sólidos, estabelecendo uma série de diretrizes sobre os mesmos. Até mesmo o Ministério do Trabalho e Emprego, através da portaria $n^{\circ} 485$, de 16 de novembro de 2005, que criou a NR 32 (BRASIL, 2005), já tratou sobre matéria pertinente aos RSS.

Tudo isso sem falar na vasta gama legislativa existente (no sentido stricto da palavra), sobre resíduos e assuntos correlatos, seja a nível federal, estadual ou municipal. Na escala federal, como exemplo, destaca-se o Capítulo VI do Título VIII da atual Constituição Federal e a lei $\mathrm{n}^{\circ}$ 6.938/81 (BRASIL, 1981), ambos dispondo sobre temas atinentes à geração, tratamento e destinação final de resíduos sólidos. Já na escala estadual, ressaltam-se as resoluções SMA nº 22 
(SÃO PAULO, 2007a) e SMA n ${ }^{\circ} 50$ (SÃO PAULO, 2007b), da Secretaria de Estado do Meio Ambiente, a primeira se consistindo numa tentativa de integração e unificação do processo de licenciamento ambiental no Estado de São Paulo e a segunda dispondo sobre projeto intitulado "Lixo Mínimo", que visa a redução da geração de resíduos sólidos no estado. $\mathrm{Na}$ escala municipal, como lembra Nogueira (2008), o artigo 30 da Constituição Federal (BRASIL, 1988) diz que compete aos municípios "legislar sobre assuntos de interesse local" (inciso I) e "suplementar a legislação federal e a estadual no que couber".

Assim, um administrador de uma unidade geradora de RSS, ao ter que tomar qualquer decisão (ainda que em questões cotidianas ou operacionais), muitas vezes se depara com um conjunto normativo extremamente amplo e por vezes colidente entre si, oriundo não só da legislação constitucional e infraconstitucional propriamente ditas, mas também de órgãos, autarquias e entidades como: CONAMA, ANVISA, Companhia de Tecnologia de Saneamento Ambiental (CETESB/SP), Associação Brasileira de Normas Técnicas (ABNT), Instituto de Pesquisas Energéticas e Nucleares (IPEN), Comissão Nacional de Energia Nuclear (CNEN), Secretarias Ambientais e de Saúde Estaduais e Municipais, etc; o que torna a gestão de tais resíduos uma tarefa extremamente difícil, com vários obstáculos. Desta forma, se o caminho errado for o escolhido, poderá ser comprometida não só a continuidade das atividades da organização (por exemplo, com a imposição de multas pecuniárias, de Termos de Ajustamento de Conduta $-\mathrm{TAC}^{\prime} \mathrm{s}^{1}$ e outras penalidades administrativas jurídicas), mas também a sustentabilidade do meio circundante e a saúde de toda uma coletividade.

Por todo o exposto, tem-se, portanto, que se qualquer pesquisa que envolva questões ambientais é hoje considerada de suma importância, o que dizer de trabalhos científicos que, dentro do conjunto de temas que englobam o meio ambiente, estudem casos concretos envolvendo a saúde pública de um município (ressaltando-se que, no presente, foram pesquisadas organizações de natureza privada, pública e mistas, de Ribeirão Preto, todas elas prestadoras de serviços de saúde), com sua problemática voltada para a questão do gerenciamento dos RSS.

Assim, dada a temática do trabalho se relacionar com a questão da sustentabilidade e da gestão ambiental, encontrando-se ainda intimamente ligada com os princípios da administração (que devem nortear o gerenciamento dos RSS), influenciando assim tanto a tomada de decisões,

\footnotetext{
1 "Aliás, é entendimento pacífico o que impõe como condição de validade do termo de ajustamento de conduta a necessidade de ele estar a abarcar a totalidade das medidas necessárias à reparação do bem lesado, ou o afastamento do risco ao bem jurídico de natureza difusa ou coletiva". (AKAOUI, 2008, p. 69).
} 
quanto sua operacionalização, a importância do estudo realizado se mostra latente, seja para os gestores e profissionais da saúde das próprias organizações pesquisadas, seja para profissionais de instituições públicas ou privadas em geral, seja para toda a coletividade.

\subsection{Objetivos}

De acordo com Severino (2007), uma dissertação de mestrado tem caráter predominantemente demonstrativo, visando com isso demonstrar uma proposição e não apenas explanar um assunto. ${ }^{2}$

Nesta linha de raciocínio, o presente trabalho foi realizado, na forma de um estudo multicaso, envolvendo organizações prestadoras de serviços de saúde (e, conseqüentemente, geradoras de resíduos atinentes a estes serviços), que atuam exclusivamente no município de Ribeirão Preto/SP, com propósito e naturezas distintas umas das outras.

Foram estudadas assim quatro instituições, partindo-se inicialmente da seguinte premissa indagativa, na verdade um problema de pesquisa: existem divergências no modo como é feito o gerenciamento dos resíduos de serviços de saúde nas organizações pesquisadas, devido à natureza (particular, pública e mistas ou que operem em regime de parceria) destas próprias organizações?

E, uma vez detectada a existência de diferenças entre as instituições estudadas, chega-se ao objetivo geral do presente trabalho, que é responder à seguinte questão: as divergências no gerenciamento dos resíduos dos serviços de saúde, caso constatadas nas organizações estudadas, devem-se ao fato de cada uma delas, dada sua natureza e peculiaridades, interpretar a seu modo a vasta gama normativa existente e adotar, dentre todas as normas, aquelas que mais se adaptem a sua realidade diária?

Assim, o objetivo geral do presente trabalho, em atenção ao próprio problema de pesquisa, se consistiu, em linhas gerais, em: identificar, através do estudo multicaso realizado, não só eventuais diferenças no gerenciamento (inclusive questões atinentes a tomadas de decisão) dos resíduos de serviços de saúde nas organizações analisadas, mas também se estas diferenças, uma vez detectadas, eram ocasionadas ou influenciadas pela pluralidade normativa existente hoje no Brasil.

\footnotetext{
2 "Esta parece ser uma exigência lógica de todo o trabalho desde que tenha objetivos de natureza científica bem definidos". (SEVERINO, 2007, p. 222).
} 
Quanto aos objetivos específicos da pesquisa, enumeram-se os seguintes:

a) Realizar levantamento das formas de gerenciamento dos resíduos de serviços de saúde das organizações pesquisadas, destacando-se eventuais particularidades de cada uma;

b) Analisar a estrutura física de cada organização, verificando-se seu enquadramento nas normas vigentes, no que tange à geração, tratamento, acondicionamento, transporte e destinação final dos resíduos de serviços de saúde;

c) Verificar como as decisões relativas à gestão dos RSS são tomadas pelos administradores, face a eventual conflito normativo (ainda que decorrente de normatividade lato, como por exemplo: portarias, decretos e regulamentos conflitantes), bem como em caso de eventualmente se depararem com normas de difícil operacionalização;

d) Realizar levantamento do grau de informações que os tomadores de decisão (diretores, gerentes, supervisores) possuem sobre a legislação e a normatividade envolvendo resíduos de serviços de saúde;

e) Realizar levantamento do grau de informações que os funcionários e empregados da área operacional possuem sobre as leis e normas aplicáveis ao seu trabalho com resíduos de serviços de saúde.

Enumerados todos os objetivos, é interessante registrar, desde logo, que, ao longo da realização do trabalho, nova problemática surgiu, relativamente à parte operacional da pesquisa (coleta de dados), mas que não comprometeu diretamente as premissas iniciais, o problema proposto ou o próprio mérito da dissertação. Tratou-se na verdade da grande dificuldade encontrada dentro de uma das quatro organizações estudadas, qual seja, o Centro de Saúde Escola da Faculdade de Medicina de Ribeirão Preto (organização que atua sob forma de parceria entre o poder público municipal, poder público estadual e autarquias estaduais), para a obtenção de autorização para a realização das entrevistas com o pessoal da área de resíduos de serviços de saúde e visita supervisionada às suas instalações. Estas dificuldades serão mais bem discutidas no capítulo atinente aos procedimentos metodológicos. 


\section{REVISÃO BIBLIOGRÁFICA}

Diversas questões influenciam de forma direta e indireta o modelo de gerenciamento dos resíduos de serviços de saúde de uma determinada organização. A seguir são apresentados temas que englobam essas questões, como as definições de gerenciamento e de gestão; como são administradas e organizadas estruturalmente as organizações públicas, privadas e mistas; o que vem a ser gestão ambiental; como é feita a gestão de instituições de saúde; como deve ser o gerenciamento de resíduos sólidos e de serviços de saúde; bem como a legislação relacionada aos RSS.

\subsection{Gerenciamento e Gestão}

Como já exposto no capítulo introdutório, o presente trabalho se propôs a pesquisar quatro organizações prestadoras de serviços de saúde, pré-selecionadas e atuantes dentro do município de Ribeirão Preto/SP, no que tange à administração e à tomada de decisões destas instituições relativamente aos RSS, razão pela qual, em seu título, existe expressa menção ao termo gerenciamento e não necessariamente à palavra gestão.

Nesta linha, para Hampton (2005), o que diferencia as tarefas da administração das demais atribuições existentes dentro do seio de uma organização, é o fato do trabalho administrativo servir para manter a funcionalidade da própria organização, auxiliando-a a atingir seus objetivos.

Já Chiavenato (2001, v. 1, p. 07) considera que o "o estudo da Administração requer uma base metodológica que lhe proporcione sustentação científica e rigor lógico". Para o autor, o enfoque meramente empírico deve ser posto de lado quando se estudam as diversas teorias administrativas, razão pela qual ele defende a aplicação da metodologia científica para esta ciência, a qual permitira uma fundamentação mais ampla das hipóteses levantadas em cada uma destas teorias.

Destarte, quando abordam temas atinentes à ciência da administração, muitas obras (a maioria escrita por autores não especializados na área), utilizam-se indiscriminadamente da palavra inglesa management para se referir, indistintamente, tanto à gestão, quanto ao gerenciamento propriamente dito. 
Contudo, embora comumente empregados como sinônimos, os termos gestão e gerenciamento têm conotação muito distinta na prática administrativa, o primeiro relacionando-se mais à escolha de um modelo administrativo, e o segundo referindo-se à prática deste modelo (ou seja, à sua aplicação) no dia-a-dia da organização.

Assim, a gestão pode ser considerada o conjunto de normas e diretrizes que regulamentam os arranjos institucionais, separando os diversos agentes e delimitando seus papéis no interior de uma organização, além de identificar os instrumentos legais que a rodeiam, bem como os mecanismos de financiamento de que dispõe, enquanto que o gerenciamento é a própria materialização do que a gestão delibera, através da ação administrativa que planeja, organiza, executa e controla todas as etapas do processo.

Rossatto (2003) adota esta linha de raciocínio, ainda que de maneira tácita, ao tecer ponderações sobre a gestão, relacionando-a com o campo teórico ligado ao conhecimento das características e capacidades da organização, diferenciando-a assim da aplicação prática destes conhecimentos no dia-a-dia, o que seria uma atribuição típica dos gerentes (de onde se infere uma alusão ao conceito do gerenciamento).

Neste sentido
(...) pode-se dizer que o estilo gerencial é uma tecnologia de organização que orienta os métodos de mobilização e o uso da mão-de-obra da empresa e define uma forma específica de organização do trabalho, caminhando atrelado e sincronizado com a estrutura organizacional e contribuindo para a implantação de mudanças e para o desenvolvimento da competência dos colaboradores. (ROSSATTO, 2003, p. 39).

Ainda, enquanto a conversão do conhecimento se consistiria num "ciclo contínuo, dinâmico e infinito de interação entre os conhecimentos tácito e explícito com a participação dos indivíduos" (ROSSATTO, 2003, p. 16), as ações seriam "o conjunto de atos e acontecimentos que devem ocorrer na organização para facilitar a implantação do Modelo, aumentar seu patrimônio intangível, propiciar a conversão do conhecimento e garantir todo o processo de gestão do conhecimento". (ROSSATTO, 2003, p. 14).

Esta diferenciação feita pelos estudiosos da administração entre a gestão e o gerenciamento, que coloca a primeira num paralelo com a teoria e o segundo com a prática, também encontra amparo em Hampton (2005), seja quando o mesmo tece considerações sobre como se deve coordenar as organizações, referindo-se tacitamente à sua gestão, seja quando 
referido autor enumera e enaltece as funções dos administradores (aos quais comumente chama de gerentes), que canalizariam as diretrizes adotadas por um dado modelo de gestão.

\begin{abstract}
A organização é um sistema. O administrador intervém nesse sistema freqüentemente sob condições turbulentas com planos, estruturas, direção e controles para vários fins. Mas a principal função do administrador é desenvolver e manter uma adaptação dinâmica entre as pessoas e as tarefas, necessária para produzir a eficiência da organização e a satisfação humana. (HAMPTON, 2005, p. 35).
\end{abstract}

Desta forma, pode-se entender a gestão como a administração no sentido lato, em que predomina a conotação política (isso tanto no setor público, quanto em empresas privadas propriamente ditas, nestas últimas se aplicando o termo política institucional), distinguindo-se assim do gerenciamento, que seria a aplicação da gestão na prática do dia-a-dia, numa conotação mais técnica, com significado stricto na administração.

Pelo exposto, e ressaltando-se mais uma vez que o estudo realizado no presente trabalho envolveu casos práticos de administração dos RSS, englobando a geração, o acondicionamento, o tratamento, o transporte e a destinação final de tais resíduos pelas organizações pesquisadas (questões estas de caráter eminentemente prático, ligadas ao cotidiano operacional da organização), nada mais correto do que a opção de se utilizar a palavra gerenciamento, em detrimento do vocábulo gestão.

\title{
2.2 Administração Pública e Privada
}

$\mathrm{Na}$ ciência da administração, quaisquer referências a organizações, entidades ou instituições partem necessariamente do pressuposto de que estas mesmas organizações, entidades ou instituições se consistam em pessoas jurídicas ${ }^{3}$.

E, como não poderia deixar de ser, no Brasil, a legislação vigente classifica as pessoas jurídicas como de direito público ou de direito privado.

Valle e Parreira (1992) ensinam que as pessoas jurídicas de direito público se dividem em pessoas jurídicas de direito público interno (citando como exemplos a união, os estadosmembros, os municípios e as autarquias - estas últimas se consistindo em entidades que exerceriam funções delegadas pelo poder público - dentre outras entidades) e pessoas jurídicas de

\footnotetext{
3 “Organização, num sentido amplo, é uma criação social estruturada para realizar objetivos preestabelecidos. A abrangência da abordagem sistêmica concebe a organização como um sistema sociotécnico no qual se destaca: o subsistema social, que inclui as variáveis humanas, e o subsistema técnico, no qual se privilegiam os recursos tecnológicos". (MATIAS-PEREIRA, 2008, p. 05-06).
} 
direito público externo (as quais exemplifica mencionando os estados estrangeiros - países - e outros entes que sejam considerados sujeitos de direito pelo direito internacional, como a ONU, a Cruz Vermelha, etc).

Quanto às pessoas jurídicas de direito privado, o mesmo autor retro mencionado as classifica em dois tipos: associações e sociedades civis, diferenciando as duas no tocante à busca pelo lucro (que seria atribuição exclusiva das segundas), bem como a busca por algum tipo de ideal, o que seria caso típico das primeiras (ao congregarem vários associados para fins científicos, políticos, esportivos, religiosos, culturais, etc.), eis que as segundas poderiam se formar com um mínimo de duas pessoas que, "contribuindo com capitais ou esforços próprios, têm por fim determinadas realizações, delas tirando lucro, que é repartido entre os sócios". (VALLE; PARREIRA, 1992, p. 35).

Esta conceituação básica sobre pessoas jurídicas de direito público e de direito privado serve para demonstrar o porquê de existirem objetivos organizacionais tão distintos entre organizações de natureza pública e privada, as quais, justamente pela adoção de modelos de gestão diferenciados, foram capazes inclusive de gerar um ramo novo dentro da ciência da administração, chamado de administração pública.

Assim, da mesma forma que existem distinções relevantes entre os conceitos de gestão e gerenciamento, existem também diferenças consideráveis na administração das organizações públicas e privadas (e também nas organizações mistas, que se consistiriam mais em casos sui generis), relativamente aos seus objetivos, metas, missão, direção, autonomia executiva, quadro de colaboradores, dentre outros quesitos.

Como exemplo, enquanto que Maximiano (2004) destaca que, em termos de política organizacional, a administração privada (ou das organizações privadas) tem (ou deveria ter) como foco prioritário a obtenção de resultados e a geração de lucro, Matias-Pereira (2008) ressalta que a administração pública deve objetivar primordialmente o atendimento dos interesses públicos.

Fica evidenciado, assim, que a gestão pública deve ser entendida como algo mais amplo do que a interpretação de gestão de negócios e do que as questões internas dos negócios de um governo. A gestão pública é mais complexa do que a gestão de negócios, focada nos clientes e na competição de mercado. (MATIAS-PEREIRA, 2008, p. 04).

Esquematicamente: 


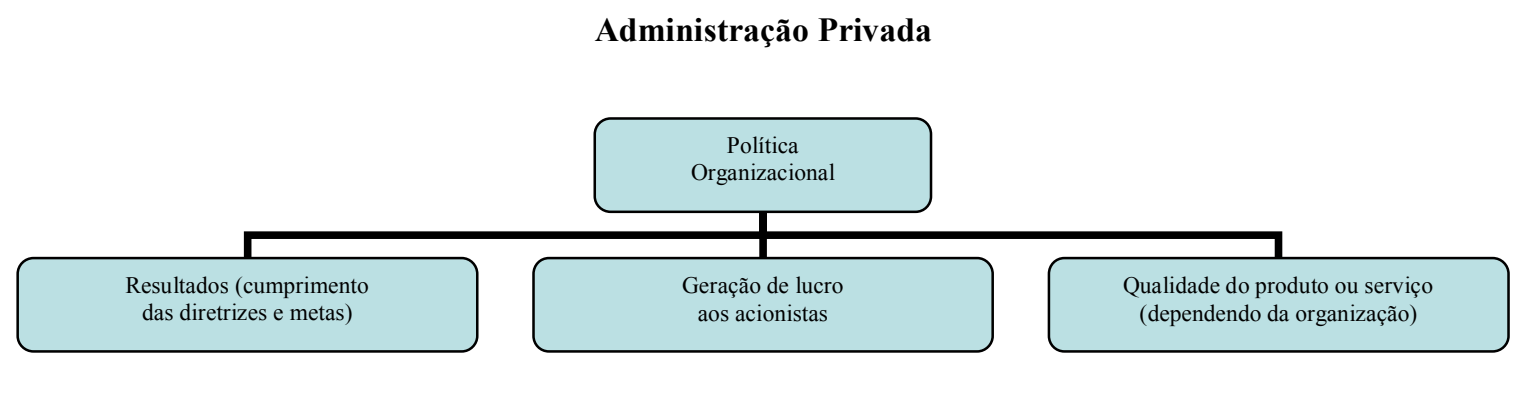

Fonte: o autor.

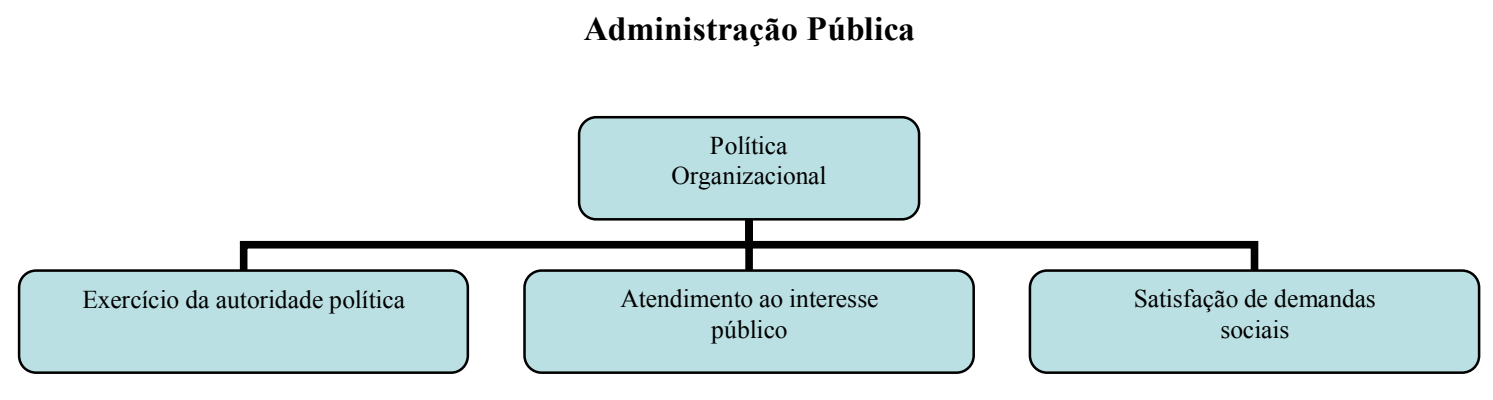

Fonte: o autor.

Outra distinção que merece destaque entre organizações de natureza privada e pública diz respeito à formação de seus quadros funcionais, prevalecendo, para cargos de direção, critérios de competência e gabarito no caso das primeiras e critérios políticos no caso das segundas; existindo também critérios diversos (contratação de mão-de-obra pouco especializada ou concurso público), para cargos operacionais ou de pequeno poder hierárquico.

Esquematicamente:

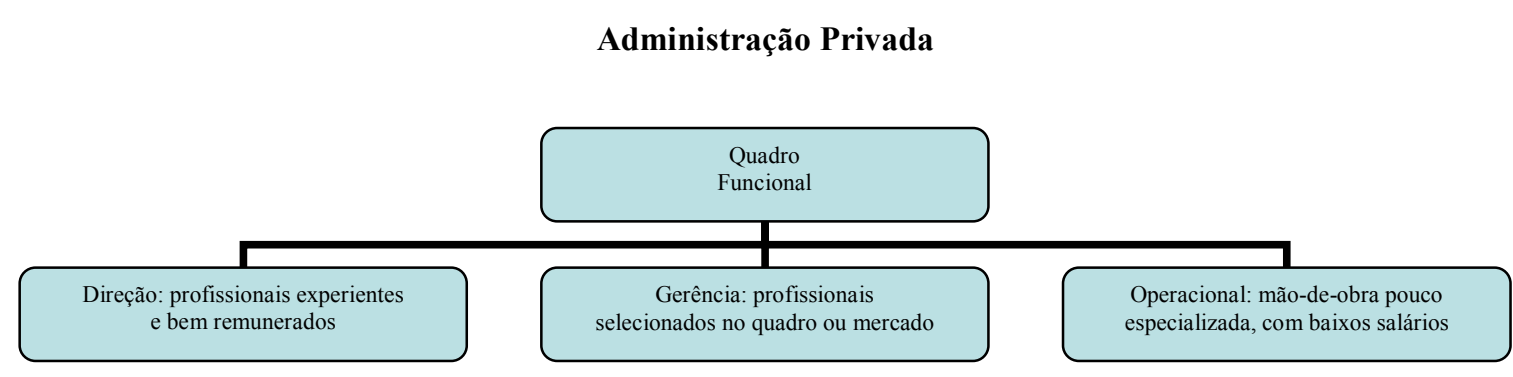

Fonte: elaborado pelo autor. 


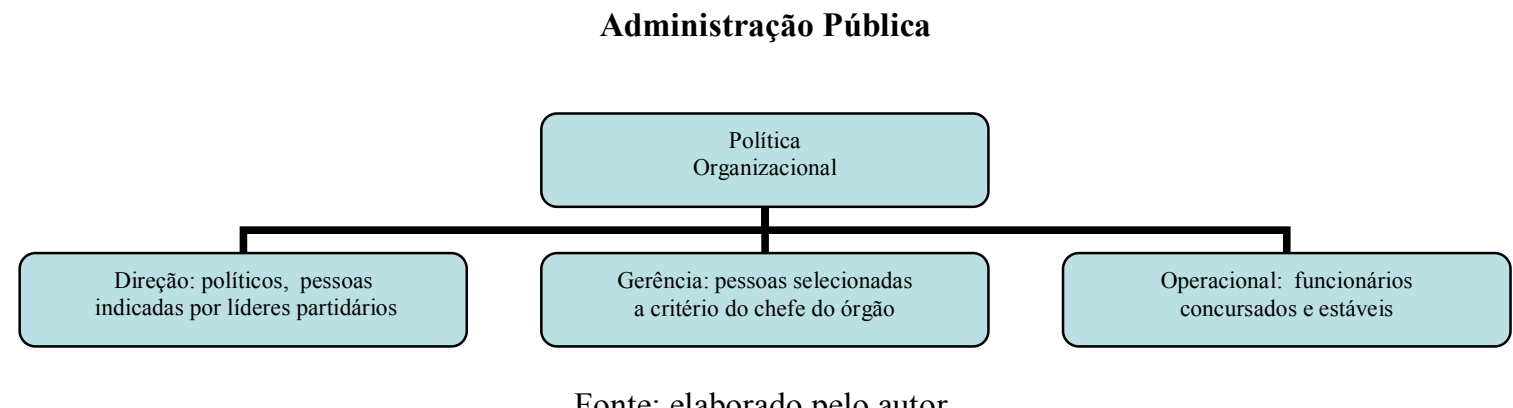

Ainda com relação às divergências existentes na administração e, num sentido mais específico, nos modelos de gestão adotados pelas organizações de natureza pública ou privada, Lima (2006, p. 351-352) considera que:

As diferenças nas experiências dos administradores dos setores público e privado são de especial interesse na esfera das relações industriais, considerando-se que a oposição de patrões às transações coletivas têm sido especialmente intensa no setor privado, e que as organizações no setor público têm apresentado de longe uma maior estabilidade. No entanto, deve haver sinais de convergência crescente entre os dois setores mesmo que consideráveis diferenças continuem existindo. Dentro do contexto de trabalho organizacional, duas hipóteses devem ser examinadas. A primeira refere-se ao compromisso com o profissionalismo e se ele é ou não uma meta no setor público. A segunda é o grau de satisfação com que se lida com as queixas individuais de administradores num nível organizacional e se existe ou não algum problema particular dentro do setor público. Os trabalhadores do setor privado tendem a aproveitar as características mais predominantes relacionadas à liberdade de pensar e agir, as oportunidades de crescer e desenvolver pessoalmente e a liberdade de sentir auto-estima, enquanto os administradores do setor público tendem a aproveitar mais as características relacionadas às satisfações como a segurança e mais oportunidade de desenvolver fortes amizades dentro do trabalho.

Tem-se, portanto, que a administração pública deve, em teoria, ser regida sempre por princípios considerados primordiais, tais como a legalidade, a moralidade, a impessoalidade e a publicidade (LIMA, 2006), o que também contribui para a construção do muro que separa este tipo de administração das formas de gestão praticadas em organizações privadas, as quais, dada a sua própria natureza, possuem maior autonomia executiva (ainda que dependente das diretrizes e metas traçadas pela direção superior e à geração de lucros) que seus pares no setor público, cuja capacidade de deliberação, inclusive para operações do cotidiano, é super restrita, dependente tanto de um orçamento previamente destinado às suas atividades, quanto à fiscalização externa exercida pelos mais variados órgãos, como Tribunais de Contas, Ministério Público, etc.

Desta forma, os entraves burocráticos aos quais a administração pública está sujeita (utilizando-se aqui o termo burocracia no sentido de formalismo intenso, e não no conceito 
clássico proposto por Max $W_{e b e r}^{4}$ ), por vezes, parecem se contrapor ao conceito de eficiência, referência quando o assunto é a administração de uma organização privada.

Num campo ainda mais teórico, Meirelles (2007) entende que a administração pública possui três sentidos distintos entre si: formal, material e operacional. O primeiro deles (sentido formal), considera que a administração pública se consiste num conjunto de órgãos criados para atender aos objetivos do governo (de qualquer esfera). O segundo (sentido material), considera que a administração pública nada mais é do que o conjunto das funções necessárias aos serviços públicos em geral. Por fim, o terceiro (sentido operacional), considera que a administração pública se define ou pode ser definida como sendo o próprio desempenho contínuo, sistemático, legalizado e técnico dos serviços prestados pelo governo em prol da coletividade.

Como forma de sintetizar todo o exposto, deve ficar aqui registrada também a regra que diz que, em teoria, as empresas públicas surgem (ou devem ser criadas) para atender algum tipo de demanda, de interesse ou de necessidade social, enquanto que as empresas privadas, geralmente, são constituídas com intuito de proporcionarem ganhos, sejam eles materializados na forma de lucros ou de quaisquer outros tipos de benesses pecuniárias para seus sócios, acionistas e investidores.

\subsubsection{Organizações Privadas}

Como já exposto, as organizações de caráter privado, quer em suas operações cotidianas, quer na tomada de decisões estratégicas, possuem um número de entraves formais e burocráticos, a serem superados, bem menor do que os seus pares de natureza pública (autarquias, órgãos, entidades, etc.), encontrando-se estas últimas muito mais atadas à questões legais e orçamentárias, que restringem sobremaneira sua autonomia administrativa.

Slack, Chambers e Johnston (2002), ao se referirem às organizações privadas, consideram que as mesmas possuem sempre três funções centrais, que são: a função marketing (que inclui a parte de vendas), a função desenvolvimento de produto ou serviço e a função produção, esta última responsável por satisfazer as necessidades e a própria demanda dos consumidores. Além destas, as organizações privadas possuiriam também outras duas funções

\footnotetext{
4 "De acordo com Weber, as organizações formais modernas baseiam-se em leis [...] A obediência é devida às leis, formalmente definidas, e às pessoas que as representam, que agem dentro de uma jurisdição. Qualquer sociedade, organização ou grupo que se baseie em leis racionais é uma burocracia”. (MAXIMIANO, 2004, p. 134).
} 
secundárias, mas que serviriam para dar suporte à função produção, quais sejam: função contábilfinanceira e função recursos humanos.

Para os autores:

[...] diferentes empresas podem tanto chamar suas funções de nomes diferentes, como também ter um conjunto diferente de funções de apoio. Quase todas as organizações, entretanto, vão ter as três funções centrais, porque todas as empresas possuem necessidade fundamental de vender seus serviços, satisfazer a seus consumidores e criar os meios para satisfação dos seus clientes no futuro. (SLACK et al. 2002, p. 32).

Por outro lado, alguns aspectos mais destacados nas principais obras da administração ao se referirem às organizações de natureza privadas, se referem ao direcionamento das mesmas, através do traçado de metas pré-definidas, para atingirem seus fins (MAXIMIANO, 2004), bem como à sua busca pelo sucesso (CHIAVENATO, 2001), além do objetivo de se atingir máxima eficiência (HAMPTON, 2005), e assim gerar ganhos, agregarem valor ou apresentarem retornos, pressupondo a idéia do lucro (ROSSATTO, 2003).

Esta última idéia (do lucro), mencionada explicitamente por Rossatto (2003) e por vários outros autores consagrados da ciência da administração, acaba sendo mesmo o ponto de partida na referência às organizações privadas (excetuando-se, por óbvio, aquelas que não possuem fins lucrativos, como, por exemplo, as fundações).

Não obstante, todas as características acima apontadas, podem e são utilizadas para, na prática, apontar as diferenças estruturais existentes entre as organizações privadas e seus pares no setor público, cuja criação, orçamento, objetivos, finalidades e meios utilizados para se chegar aos fins pretendidos, ocorrem e se materializam de uma maneira totalmente distinta.

\subsubsection{Instituições ou Entidades Públicas}

Alguns autores das ciências jurídicas utilizam o termo entidades, quando se referem às mesmas pessoas jurídicas que os cientistas da administração designam por organizações. Esse seria o caso do professor Hely Lopes Meirelles, em obra reeditada e atualizada, lançada no ano de 2007.

Desta forma, de acordo com Meirelles (2007), entidade é "pessoa jurídica, pública ou privada" (p. 65); enquanto órgão é "elemento despersonalizado incumbido da realização de atividades da entidade a que pertence, através de seus agentes". (p. 65-66). Para o autor, na organização política e administrativa brasileira, existiriam então cinco classificações possíveis 
para as entidades (no caso, as organizações), qual seja: estatais, autárquicas, fundacionais, paraestatais e empresariais. As entidades estatais seriam as pessoas jurídicas de direito público que integrariam a estrutura constitucional do próprio Estado, tais como a União, os Estadosmembros, os Municípios e o Distrito Federal. Já as entidades autárquicas também seriam pessoas jurídicas de direito público, mas com natureza meramente administrativa, criadas em virtude de lei para realização de atividades ou serviços descentralizados da própria entidade estatal que as criou. Por seu turno, as fundações podem ser pessoas jurídicas de direito público ou privado, subordinadas sempre à lei que definir suas respectivas áreas de atuação. Outrossim, as entidades paraestatais seriam pessoas jurídicas de direito privado autorizadas por lei a prestar serviços ou realizar atividades de interesse público, atividades e serviços estes que não são exclusivos do Estado. Por fim, as entidades empresariais seriam pessoas jurídicas de direito privado, instituídas sob a forma de sociedade de economia mista ou empresa pública, com finalidade de prestação de serviços públicos que possam ser explorados de maneira empresarial, ou de exercer atividade econômica de relevante interesse coletivo.

Mesmo se referindo exclusivamente às organizações ligadas direta ou indiretamente ao poder público, o que se denota da classificação acima, feita pelo professor Meirelles (2007) é o caráter econômico ou mercantil com que destaca as atribuições das entidades empresariais, notadamente quando comparadas aos demais tipos de entidades (estatais, autárquicas, fundacionais e paraestatais), restando implícita em suas considerações, no tocante a este tipo de empresa (pública), a idéia do lucro, da mesma forma que tantos autores consagrados das ciências da administração fazem menção, quando expõem suas teorias sobre as organizações de caráter privado.

De todo modo, às organizações ou entidades de caráter público podem ser aplicados princípios básicos da ciência da administração, semelhantes àqueles utilizados com as organizações privadas. Como exemplo, menciona-se a questão relativa à estruturação destas organizações, cujos pressupostos, originários nas escolas clássicas da administração, aplicam-se indistintamente àquelas pertencentes ao campo público ou privado.

Neste sentido:

A Teoria Clássica concebe a organização como uma estrutura de órgãos e cargos, com uma forma e disposição das partes, além do inter-relacionamento entre essas partes. Essa maneira de conceber a estrutura organizacional é influenciada pelas concepções antigas de organização (como a organização militar e eclesiástica), tradicionais, rígidas e hierarquizadas. (CHIAVENATO, 2001, p. 96). 
Para Chiavenato (2001), as organizações, sejam elas públicas ou privadas, possuem, em sua estruturação, uma cadeia de comando que define as posições ocupadas pelas pessoas dentro da mesma, estabelecendo assim, de maneira clara, o seu campo hierárquico. $\mathrm{O}$ autor também chega a fugir do lugar comum quando tece considerações sobre o caráter de "força viva, móvel e fluida" (p. 122) das organizações, lembrando também que elas representam "pessoas que reagem e respondem a estímulos que não podem ser definidos com precisão" (p. 122), ou seja, as organizações são compostas por pessoas, daí o porque todos os seus problemas derivem fundamentalmente de relações humanas.

Ao tecer tais considerações, Chiavenato (2001) opõe seu pensamento ao modo estritamente formal e jurídico de encarar as organizações, quer no tocante à sua estruturação, quer no tocante às suas funções e operacionalidade, como procede Meirelles (2007).

Por fim, Matias-Pereira (2008) faz questão de ressaltar a questão do planejamento estratégico, como fator de primordial importância não só às organizações privadas, mas também a qualquer entidade administrativa do poder público. De acordo com ele:

\footnotetext{
É perceptível a importância dada na fase atual, tanto no setor privado como no público, para a questão do planejamento estratégico. Destaca-se entre essas razões a velocidade das mudanças nos ambientes de todas as empresas e organizações públicas, especialmente nos campos econômico, social, tecnológico e político. Assim, a empresa ou organização pública somente poderá evoluir se ajustar à conjuntura. (MATIASPEREIRA, 2008, p. 89).
}

Comprovado então que, mesmo com suas diferenças, singularidades e peculiaridades, as organizações públicas possuem também pontos de interesse comum com suas similares de natureza privada.

\subsubsection{Parcerias Público-Privadas (PPPs)}

Como já exposto em tópicos anteriores, enquanto as organizações privadas buscam, via de regra, a obtenção de lucro, as empresas e instituições públicas surgem para atender às mais diversas demandas sociais, notadamente em áreas consideradas estratégicas, como infra-estrutura, saúde, transporte, educação, segurança, etc.

Ocorre que, nos últimos anos, seja a nível nacional ou internacional, estão surgindo alianças estratégicas entre estes dois tipos de organizações de natureza tão oposta e que trabalham de maneira e com objetivos tão distintos. Estas alianças, entre o Estado de um modo geral, e a 
sociedade (ou a iniciativa privada) em particular, visa, em síntese, atenuar disfunções operacionais do primeiro, bem como maximizar os resultados da ação social em geral, importando para a administração de órgãos e entidades públicas, conceitos como eficiência ou excelência, os quais são comumente utilizados quando a referência são os modelos de gestão das organizações privadas.

Em capítulo escrito por Monteiro na obra em que Sundfeld (2005) figura como organizador, argumenta-se que estas novas formas de relacionamento que vêm surgindo nos últimos anos entre o Estado e a sociedade privada é fruto de um fenômeno mundial de escassez de recursos públicos frente às necessidades estruturais cada vez maiores das sociedades modernas no que tange às áreas mais essenciais, como transportes, saneamento, presídios, saúde e habitação.

Ainda de acordo com a obra de Sundfeld (2005), os modelos utilizados no Brasil para se atrair parceiros privados para a realização de negócios e empreitadas públicas, estariam todos previstos na Lei das Licitações - Lei n ${ }^{\circ}$ 8.666/1993 (BRASIL, 1993), assim como os mecanismos de concessão de serviços públicos (permissões, autorizações, franquias e terceirização em geral), estariam todos previstos na Lei $\mathrm{n}^{\circ}$ 8.987/95 (BRASIL, 1995).

Neste sentido,

\footnotetext{
Dentre tais mecanismos jurídicos, especial atenção tem sido dada aos contratos celebrados com base na Lei 8.987/1995, por serem instrumentos capazes de fomentar a participação privada no financiamento da infra-estrutura pública. Por meio deles o Estado pode transferir o ônus do financiamento aos particulares, superando, assim, os limites de endividamento do setor público. De fato, a Lei $8.987 / 1995$ permite a celebração de estruturas contratuais complexas, do ponto de vista financeiro, para fazer frente à demanda estatal por uma maior participação privada nos negócios públicos. É o caso, por exemplo, dos contratos do tipo DBFO (design, build, finance and operate) e BOT (build, operate and transfer), instrumentalizados no Brasil por meio de contratos de concessão e de projetos financeiros estruturados (Project finance). (SUNDFELD, 2005, p. 80-81).
}

Oncala (2006), em artigo publicado na revista Conexão Migalhas, ressalta que, após um intenso período de debates no Congresso Nacional, foi promulgada, no Brasil, a lei $n^{0} 11.079$, no dia 31 de dezembro de 2004 (BRASIL, 2004), a qual instituiu, formalmente, as parcerias públicoprivadas (PPPs) no país.

Esclarece a mencionada autora que:

De acordo com a Lei aprovada, as parcerias público-privadas são definidas como contratos administrativos de concessão que se manifestam sob duas modalidades: (i) a de concessão patrocinada, para a prestação de serviços públicos ou realização de obras 
públicas (com posterior prestação de serviço público) em que há contraprestação pelo Estado, adicionalmente à tarifa cobrada dos usuários; e (ii) a de concessão administrativa, em que o serviço público (podendo envolver obra pública ou fornecimento e instalação de bens) é prestado direta ou indiretamente à Administração Pública, recebendo integralmente desta sua contraprestação. Exemplos de concessão patrocinada seriam as construções e operações de rodovias e ferrovias, ao passo em que as concessões administrativas caberiam para os casos de contratação para a construção e operações de hospitais, presídios e escolas. (ONCALA, 2006, p. 47).

Para Poltronieri (2005), as PPPs são, hoje, mais do que uma realidade, uma necessidade no país, devido às limitações estruturais do estado brasileiro na prestação dos serviços públicos, quer em razão da promoção de políticas meramente assistencialistas por meio de interesses políticos mediatos, quer em razão dos erros e abusos que ocorrem na gestão dos recursos públicos, através da concessão de subsídios às iniciativas pública e privada, que não trazem qualquer benefício direto à maioria da população.

Não obstante, na esteira de toda essa discussão, está sendo efetuada, de maneira gradual, uma reforma estrutural em todo o sistema de saúde brasileiro, a qual começou em meados da década de 1980. Referida reforma visa fazer com que o poder público obtenha uma maior qualidade dos serviços de saúde prestados, a custos bem menores, buscando assim a materialização dos conceitos de eficiência e excelência, do mesmo modo que ocorre com as organizações privadas.

Salazar et al. (2008) em artigo que consta como organizadora, extraído do site do Instituto Brasileiro de Defesa do Consumidor (IDEC, 2008) - esclarece que, um dos pontos mais destacados da reforma do sistema público de saúde no Brasil nos últimos 20 (vinte) anos foi a criação do Sistema Único de Saúde (SUS). De acordo com ela, o SUS prevê expressamente a participação do setor privado na prestação dos serviços públicos de saúde, ou seja, as ações serão realizadas pelos serviços públicos e, de forma complementar, pelo setor privado (ainda que, preferencialmente, pelo setor filantrópico e sem fins lucrativos, por meio de contrato administrativo ou convênio, o que não descaracteriza a natureza pública dos serviços e nem exclui a realização destes mesmos serviços por hospitais privados administrados como empresas que almejam o lucro).

Interessante destacar que o objetivo primordial desta participação destina-se às áreas mais carentes ou regiões mais afastadas do Brasil, em que o poder público não possui estrutura adequada para atender a toda a demanda por serviços de saúde, repassando em parte esta 
responsabilidade para organizações privadas ali existentes, cujos custos ${ }^{5}$ com esses atendimentos, exames e outros procedimentos médicos são inteiramente bancados pelo poder público.

E, dentre os inúmeros programas bancados pelo SUS, através também da utilização da estrutura da iniciativa privada, Rivera (2003), destaca o Programa de Saúde da Família (PSF). Para ele, apesar de existirem pontos críticos a este programa, existe a esperança de que, no futuro, com a estruturação da rede urbana e o nivelamento do nível salarial entre os profissionais das entidades públicas e organizações privadas que prestem este tipo de atendimento, ocorra "a consolidação do controle social e com uma rede hierarquizada de serviços de saúde, capaz de responder adequadamente à necessidade de atendimento" (RIVERA, p. 177), sendo certo que, em um cenário assim, o PSF (idealizado como típica parceria entre o poder público e a iniciativa privada, por meio do SUS), produziria melhorias significativas no quadro de saúde da população.

Ressalte-se ainda que, como ensina Poltronieri (2005), as parcerias público-privadas (PPPs) se consistem num tipo particular de contrato administrativo de concessão, ou seja, trata-se de um tipo de concessão de serviço público não disciplinado pela lei no ${ }^{\circ} 8.987 / 1995$ (a qual dispõe sobre as concessões de serviço público comuns).

De acordo com o mencionado autor:

\begin{abstract}
A Lei de Parcerias define sua abrangência de forma objetiva, aplicando-se à União, Estados, Distrito Federal e Municípios órgãos da Administração pública direta e indireta como as autarquias, fundações públicas, empresas públicas, sociedades de economia mista e demais entidades controladas direta ou indiretamente pelo Estado. Aplica-se ainda aos fundos especiais." (POLTRONIERI, 2005, p. 100).
\end{abstract}

Portanto, seja envolvendo a área da saúde (com atuação de organizações particulares fornecendo serviços e outros procedimentos clínicos para a população em geral, através do custeio destes procedimentos pelo SUS), seja em outras áreas da administração, as PPPs são um assunto extremamente novo, razão pela qual qualquer estudo de caso concreto envolvendo este tipo de transação, trará, com certeza, contribuições ao campo científico.

\footnotetext{
5 "Embora as receitas acumulem-se como resultado da produção médica, isso não significa que o dinheiro necessário para os custos diretos e indiretos esteja disponível. (...) A existência de bens, direitos e obrigações, no hospital, e seu controle pela contabilidade, a determinação, o controle e a análise dos custos pela gerência de custos, a possibilidade de decidir antecipadamente o que fazer gerada pelo orçamento hospitalar demandam decisões otimizadas de investimentos, financiamentos e distribuição de lucros que são concretizadas pela administração financeira hospitalar”. (MARTINS, 2002, p. 20-21).
} 


\subsection{Gestão Ambiental}

Atualmente os principais temas relacionados à gestão ambiental ${ }^{6}$ tornaram-se constantes não só no seio da discussão pública e junto aos formadores de opinião, mas também junto às grandes organizações, encontrando-se praticamente onipresentes quando as mesmas traçam suas metas, diretrizes e objetivos estratégicos.

Não obstante, o tema se faz presente também nas principais escolas de administração no país e no mundo.

Mas nem sempre foi assim. Nascimento, Lemos e Mello (2008, p. 17) explicam que

Até quase o final do século XX, a gestão ambiental e a gestão social eram vistas como custo: despesas necessárias para que as organizações atendessem à legislação. Foi somente a partir de 1994 que o movimento internacional de responsabilidade social começou a ter mais visibilidade e reconhecimento. Nessa época surgiu uma organização norte-americana denominada Business for Social Responsibility (BSR) que rapidamente alcançou repercussão mundial e gerou dezenas de novos organismos independentes vinculados à mesma idéia.

Para os autores supra mencionados, foi apenas com a criação do Conselho Organizacional Mundial para o Desenvolvimento Sustentável (cuja sigla, em língua inglesa, é WBCSD), no ano de 1998, que foram lançadas as bases da idéia da responsabilidade social corporativa, considerando aí, em seu conjunto, todos os agentes interessados direta ou indiretamente no tema, bem como englobando os conceitos de responsabilidade social e ambiental.

Seguindo linha de entendimento parecida, Seiffert (2007, p. 45) considera que "o processo de gestão ambiental surgiu como uma alternativa para buscar a sustentabilidade dos ecossistemas antrópicos, harmonizando suas interações com os ecossistemas naturais".

No Brasil, relativamente aos elementos do processo de gestão ambiental, Ribas (1997, p. 109) pondera que

[...] haveria que se tomar como válida a diferenciação, segmentação entre os seguintes atores: (1) "Governo" (Governos Federal, Estaduais, do Distrito Federal, Municipais, ou, alternativamente, Poderes Executivo, Legislativo e Judiciário, bem como Ministério

\footnotetext{
6 "No que se refere ao tema meio ambiente, o termo "gestão" assume um significado muito mais amplo, pois envolve um grande número de variáveis que interagem simultaneamente. Sendo assim, para gerenciar as atividades humanas sob o prisma da questão ambiental, não se pode perder a visão do todo, a integração entre as partes e o objetivo maior em que se insere a ação ou a atividade que está se desenvolvendo ou, em outras palavras, o que ela representa na globalidade da questão ambiental". (SOUZA, 2000, p. 27).
} 
Público); (2) "Empresas" (públicas, privadas, nacionais, transnacionais); (3) "Mercado" (cenário final resultante do embate, da conjugação de forças de bens e serviços e suas respectivas oferta e demanda de fatores de produção, dentro de um sistema de preços, em ambiente capitalista); e (4) "Sociedade" (somatório final da interação de vários segmentos que a comporiam, a exemplo dos movimentos populares, associações de bairro, organizações não-governamentais ambientalistas ou não, opinião pública, mídia, partidos políticos, igreja, enfim, segmentos diversos, mobilizados ou não).

Não obstante, Dias (2006) menciona que todas as opiniões hoje convergem para a busca de uma nova estratégia de desenvolvimento, a título mundial, que passe a contemplar o meio ambiente não mais como mero depositário dos dejetos da civilização industrial, mas sim como parte integrante e necessária de todo o progresso que a humanidade ainda almeje conhecer e descobrir.

Esta visão hoje predomina tanto em ambientes macro (tratados e protocolos internacionais versando sobre temas ambientais, como, por exemplo, o Protocolo de Kyoto, e também ações conjuntas promovidas por organizações internacionais), como em ambientes micro (através de ações traçadas na forma de diretrizes e metas, dentro das mais variadas organizações, quer de caráter público ou privado).

Por outro lado, quanto aos ambientes macro e micro em que a gestão ambiental deve se materializar, Nascimento, Lemos e Mello (2008) têm uma visão diferente, classificando tais ambientes não conforme as normas de direito público administrativo e internacional, mas de acordo com uma visão mais técnica, econômica e social, enumerando como variáveis do macroambiente aspectos tecnológicos, demográficos, sócio-culturais, político-legais e outros (e não simplesmente as fronteiras transnacionais entre os países, além de organismos, tratados e protocolos internacionais); e como variáveis do microambiente elementos como fornecedores, intermediários do mercado, concorrentes, stakeholders e clientes (possuindo assim uma visão puramente organizacional quanto ao tema).

Outrossim, muitos autores relacionam os conceitos de gestão ambiental com o próprio princípio do desenvolvimento sustentável, este último podendo ser conceituado da seguinte forma:

PRINCÍPIO DO DESENVOLVIMENTO SUSTENTÁVEL.

A terminologia empregada a este princípio surgiu, inicialmente, na Conferência Mundial de Meio Ambiente, realizada, em 1972, em Estocolmo e repetida nas demais conferências sobre o meio ambiente, em especial na ECO-92, a qual empregou o termo em onze de seus vinte e sete princípios. (FIORILLO, 2008, p. 27). 
Nesta mesma linha de raciocínio, Seiffert (2007) vai mais além, considerando que a gestão ambiental não só se relaciona com o princípio do desenvolvimento sustentável, mas se consiste em baluarte essencial para a própria materialização deste último conceito, ou seja, serve de alicerce para o mesmo.

Afirma a autora (2007.p. 48) que

\begin{abstract}
Nos últimos anos, o conceito de gestão vem sendo utilizado para incluir, além da gestão pública do meio ambiente, os programas de ação desenvolvidos por empresas e instituições privadas não governamentais, de modo a administrar sua atividade dentro dos modernos princípios de proteção do meio ambiente. Dessa forma, o conceito de gestão ambiental tem evoluído na direção de uma perspectiva de gestão compartilhada entre os diferentes agentes envolvidos e articulados em seus diferentes papéis.
\end{abstract}

Baseado no exposto, conclui-se que tanto nas entidades públicas, como nas empresas privadas, de um modo geral, conceitos como ética e responsabilidade sócio-ambiental são cada vez mais difundidos, sendo certo que, para Lima (2006, p. 179)

[...] os princípios que norteiam as decisões e comportamento de gerentes relativamente à questão de determinar se estão moralmente aceitáveis ou não compõem o que se denomina de "ética gerencial". Já o conceito de "responsabilidade social" é uma extensão dessa idéia e refere-se à obrigação gerencial de fazer opções e agir de modo que a organização contribua para o bem-estar e o interesse da sociedade, bem como o dela própria.

É importante destacar que, atualmente, no Brasil, grandes avanços surgiram no campo jurídico, os quais, por sua vez, acabaram por gerar reflexos quase imediatos na administração das organizações, notadamente no que se refere às questões relativas ao meio ambiente e à sustentabilidade de tudo aquilo que as circunda.

Uma das maneiras de demonstrar este avanço legal (sem esquecer do muito que ainda há que se fazer, a título legislativo, sobre temas ecológicos) é a questão do licenciamento ambiental. Neste sentido, Farias (2007, p. 30), explica que:

O licenciamento ambiental tem como objetivo efetuar o controle ambiental das atividades efetiva e potencialmente poluidoras, através de um conjunto de procedimentos a serem determinados pelo órgão administrativo de meio ambiente competente, com o intuito de garantir o meio ambiente ecologicamente equilibrado e de defender a qualidade de vida da coletividade.

Para o mencionado autor, o poder público efetiva o controle ambiental das mais diversas formas de organização, por meio de uma série de exigências e de procedimentos administrativos impostos para regularização de atividades potencialmente nocivas ao meio ambiente, adequando 
as normas e padrões de qualidade previamente existentes a cada caso que lhe seja apresentado. Por exemplo, o controle ambiental ocorre quando as autoridades públicas competentes acompanham o potencial de geração de poluentes líquidos, de resíduos sólidos, de emissões atmosféricas e de ruídos emanados por determinados tipos de empresas, estabelecendo limites sob pena da aplicação de punições legais (multas, processos administrativos, cassação de licença ou alvará de funcionamento, etc.). Assim, o controle ambiental exercido pelo Poder Público se materializa no licenciamento, o qual nada mais é do que é um instrumento que integra o empreendedor, "cuja atividade pode interferir na estrutura do meio ambiente e o Estado, que garante a conformidade com os objetivos dispostos na Política Nacional do Meio Ambiente" (FARIAS, 2007, p. 31).

Por meio do Ministério Público, um outro instrumento que a sociedade se utiliza para obrigar os gestores a promoverem uma administração sustentável das organizações que representam (ou seja, considerando em suas diretrizes a variável "meio ambiente"), e que serve também para fiscalizar o modo de atuação destas próprias organizações, é o compromisso de ajustamento de conduta ambiental, conhecido como Termo de Ajustamento de Conduta, representado pela sigla TAC.

Sobre este dispositivo, Akaoui $(2008$, p. 97) faz questão de frisar que

\begin{abstract}
Em se tratando de pessoa jurídica, de direito privado, especialmente, deve o tomador do ajustamento de conduta procurar se acautelar de sorte a imputar a ela a necessidade de transferir as obrigações contidas no título a sua eventual sucessora na atividade em caso de alienação ou privatização (no caso de estatais), pois, caso contrário, a nova empresa ou pessoa física que se estabeleça não estará vinculada às obrigações do compromisso firmado.
\end{abstract}

Sabendo que têm que se ajustar à legislação atualmente vigente (a qual nada mais representa do que a própria maturidade da sociedade, que finalmente descobriu a importância da preservação do meio ambiente, como forma de garantir a sustentabilidade de vida das próprias gerações futuras), sob pena de sofrer punições (e inclusive comprometer as próprias atividades da pessoa jurídica que representam), os gestores tendem cada vez mais em optar por diretrizes que conciliem os objetivos da organização, com o desenvolvimento sustentável e a qualidade ambiental. Neste mesmo sentido, Souza (2000), para quem “a gestão ambiental pode ser entendida, conforme mencionado, como o conjunto de procedimentos que visam à conciliação entre desenvolvimento e qualidade ambiental" (p. 27). 
Ainda de acordo com Souza (2000), é na legislação, na política ambiental e na participação da própria sociedade, que a gestão ambiental encontra suas ferramentas de ação.

Pelo exposto, pode-se afirmar ser praticamente inegável a importância de qualquer questão relativa ao meio ambiente, seja no país, seja no mundo atual, notadamente se esta questão envolver diretamente a saúde pública de toda uma coletividade urbana, como, por exemplo, a que diz respeito à produção, ao acondicionamento, ao tratamento, ao transporte e à disposição final dos resíduos dos serviços de saúde - RSS, dentro de um município, conforme objetivos específicos de estudo do presente trabalho.

\title{
2.4 Gestão de Instituições de Saúde
}

Sobre as organizações de um modo geral (e especificamente sobre as organizações que prestam serviços na área da saúde), pode-se dizer que

\begin{abstract}
Devido a sua condição de artificial e da necessidade de estar continuamente alterada para manter-se no tempo, é preciso que alguém a administre, ou melhor, comande-a com muita competência para torná-la competitiva e, conseqüentemente, possa vir a fazer frente à competição acirrada nestes tempos de grandes mudanças. A competência, seja ela empresarial ou gerencial, depende de pessoas com flexibilidade e criatividade que, com suas estratégias e inovações, conseguem sempre estar à frente dos acontecimentos que as tendências do mundo globalizado possam apresentar repentinamente. Sobressaise em resolver as dificuldades quem as resolve antes que apareçam; isto é competência. Mudanças inteligentes e contemporâneas que visam à qualidade, à satisfação e ao encantamento dos clientes conferem aos bens e serviços o status de competitivos; isto é competitividade. A busca simultânea, de dois ou mais indivíduos, de uma mesma meta, porém escassa, de sorte que a pessoa alcance a sua se os outros forem impedidos de obtê-la, determina um estado de competição. Entretanto, tendo em nossas instituições gestores competentes e bens e serviços competitivos, nossas chances de vencer qualquer competição no mercado são explicitamente maiores. (TARABOULSI, 2004, p. 28).
\end{abstract}

Para justificar o raciocínio acima transcrito, Taraboulsi (2004) invoca os princípios contidos na obra milenar "Arte da Guerra", de Sun Tzu, ponderando que o estilo gerencial adequado para determinada instituição de saúde é aquele que permite que sua gestão permaneça aberta e atenta, tanto às pessoas envolvidas, quanto às mudanças ocasionadas pela renovação dos paradigmas, visando sempre a inovação e a flexibilidade como formas de os atingir resultados almejados. O autor ainda entende que o responsável pelo caminho a ser seguido por qualquer instituição de saúde precisa, necessariamente, "dominar a arte de gerenciar, exigindo do gestor uma seqüência de ações inteligentes - planejar, inovar e modernizar - que levam à consecução da qualidade dos serviços hospitalares" (TARABOULSI, 2004, p. 29). 
Desta forma, como o presente trabalho se propõe a analisar casos concretos de gerenciamento de RSS em organizações de saúde (com o fito de compará-las), a bibliografia a ser utilizada não pode e nem irá se ater apenas às obras gerais de administração ou de direito ambiental, mas também e principalmente, às obras específicas dos autores mais reconhecidos em gestão hospitalar e de unidades de saúde, bem como pertinentes à área de resíduos sólidos.

A utilização de bibliografia multidisciplinar (nas áreas da administração, direito, meio ambiente, saúde e de resíduos) decorre da própria natureza do trabalho, uma vez que constatadas diferenças dentre as organizações de saúde a serem pesquisadas, as conclusões deverão se basear nesta vasta gama de conhecimentos distintos (porém complementares, uma vez que o conhecimento científico é uno); além, é claro, de se considerar também as diferentes visões dos próprios empregados, diretores e gerentes entrevistados, decorrentes basicamente dos modelos de gestão adotados em suas respectivas instituições.

A adoção de determinados modelos de gestão (campo teórico da administração) por parte de uma organização da área da saúde, ocasiona reflexos imediatos e plenamente identificáveis no gerenciamento (aspecto prático) de seus problemas cotidianos. Por este motivo, é certo que qualquer modelo de administração adotado para uma dada organização hospitalar deve levar em conta, antes de ser implementado, todas as atividades que esta mesma organização desempenha.

Sobre esta visão geral das atividades hospitalares desempenhadas por uma dada organização que atua na área, Martins (2002, p. 36) esclarece que

\begin{abstract}
As atividades constituem o fundamento do sistema de gerenciamento de custos hospitalares. Uma atividade descreve o modo como um hospital emprega seu tempo e recursos organizacionais para alcançar os objetivos hospitalares. As atividades consomem recursos organizacionais para gerar a produção médica, e sua principal função é transformar recursos organizacionais (medicamentos, materiais médicos, serviços de enfermagem, serviços médicos, serviços de equipamentos, serviços públicos etc.) em serviços hospitalares. Por exemplo, a atividade de administração produz serviços de informação, de faturamento, de recebimentos e planejamento de recursos financeiros, etc.
\end{abstract}

$\mathrm{Na}$ seqüência, o autor mencionado continua com suas ponderações propondo o estabelecimento de diferenças entre os conceitos de processo e tarefa, dentro de um hospital. Para Martins (2002), o processo estaria mais ligado ao conceito de procedimento, se consistindo num conjunto de atividades relacionadas e interdependentes que culminariam na produção e nos serviços hospitalares; enquanto que o conceito de tarefa abrangeria todo o trabalho realizado por 
pessoas, equipamentos, instalações hospitalares e outros, relacionadas aos procedimentos médicos (destacando ainda que as atividades que ocorrem nos departamentos de apoio de um hospital são tão importantes para se atingir objetivos quanto aquelas que ocorrem diretamente na área de produção médica propriamente dita).

De todo modo, reitera-se mais uma vez a idéia de que qualquer estilo gerencial nada mais é do que a materialização prática dos modelos de gestão adotados numa dada organização, seja ela prestadora de serviços de saúde ou não. Estes modelos de gestão, materializados através de diferentes práticas de gerenciamento, quando considerados em conjunto, constituem aquilo que, em sentido lato, designa-se como a administração geral, ou o modo de se administrar, daquela determinada organização.

Como explica Maximiano (2004), um dos baluartes que ajudaram a compor o que se entende hoje por administração é o planejamento (juntamente com os demais conceitos de organização, execução e controle). Para o autor, o planejamento se consiste na definição dos objetivos e recursos utilizados por uma dada organização, sendo certo que todas as decisões devem envolver tanto o planejamento, quanto a organização, execução (ou direção) e o controle. Além disso, o planejamento encontra-se também diretamente ligado à estratégia da organização, não sendo exagero afirmar, em dedução, que, sem planejamento não há administração e, conseqüentemente, não existe gestão e nem gerenciamento.

Historicamente, tem-se que

O planejamento estratégico em saúde surge, em meados da década de 70 , como a tentativa de reconhecer a complexidade ao introduzir as idéias da superioridade do político sobre o econômico e da diversidade de atores-sujeitos do ato de planejar. A questão da viabilidade política passa a ocupar um papel central e a definição de propostas/compromissos de ação, a depender de uma articulação que se abre a uma perspectiva policêntrica de análise. (RIVERA, 2003, p. 18).

Rivera (2003) ainda destaca que "talvez o grande mérito do planejamento estratégico tenha sido trazer à tona a necessidade de diálogo" (p. 18). Para o aludido autor, a solução para vários problemas envolvendo o planejamento estratégico dentro das organizações de saúde, assim como para outros problemas de natureza diversa, está na negociação entre os mais diversos setores, entre si, e entre eles e os parceiros, prestadores de serviço, colaboradores, fornecedores, interessados e a sociedade em geral.

Outrossim, estabelecido um planejamento estratégico e traçados os parâmetros pretendidos com a adoção de determinado modelo de gestão numa organização de saúde, deverá 
referido modelo ser avaliado de tempos em tempos, por métodos científicos, com o fito de constatar se o mesmo está atingindo os fins esperados e se os objetivos da instituição estão sendo alcançados.

Quanto à avaliação dos modelos de gestão das instituições prestadoras de serviços de saúde, Bosi e Mercado (2004, p. 124-125) esclarecem que a mesma

[...] é ou deve vir a ser um procedimento habitual e cotidiano na gestão, cujos elementos devem ser articulados com as ações técnicas e administrativas. Portanto, a avaliação é parte integrante e necessária do planejamento e indispensável no processo de tomada de decisões. A avaliação é assim considerada como um campo de aplicação de outras áreas do conhecimento e outras ciências (Tanaka\& Melo, 2001) e uma tarefa que deve ser assumida por trabalhadores e gestores dos serviços de saúde. Deste modo, uma tarefa imprescindível é distinguir as diferenças entre a avaliação como pesquisa de avaliação para subsidiar o processo de gestão.

Com relação aos problemas atualmente enfrentados na gestão das organizações prestadoras de serviços de saúde, Guimarães e Prochnik (2005), em artigo extraído do site da Universidade Federal do Rio de Janeiro - UFRJ), propõem a existência de duas categorias diferentes de desafios para os gestores hospitalares, quais sejam: desafios do ambiente interno (inerentes ao funcionamento e à administração da própria organização) e desafios do ambiente externo (inerentes ao ambiente onde esta organização se situa e sua interação com os diferentes agentes que a circundam).

Neste sentido

Os desafios do ambiente externo são o maior rigor dos processos regulatórios, a maior variedade de necessidades dos consumidores e a maior pressão competitiva. No ambiente interno, os principais desafios para a gestão da saúde são: conflitos entre gestores e médicos, conflitos entre as proposições de valor de diferentes tipos de consumidores, falta de métodos para mensuração do desempenho e sistemas de informação ineficientes. (GUIMARÃES; PROCHNIK, 2005).

Esquematicamente:

\section{Desafios dos Gestores Hospitalares (Contexto Externo)}

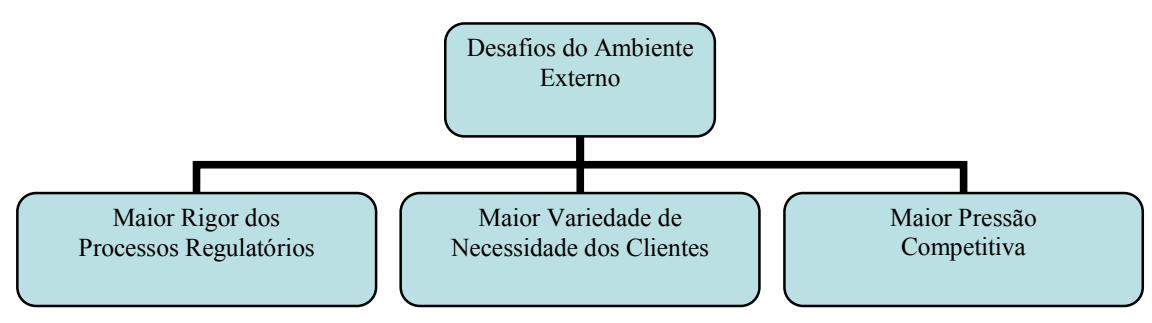

Fonte: elaborado pelo autor.

\section{Desafios dos Gestores Hospitalares (Contexto Interno)}




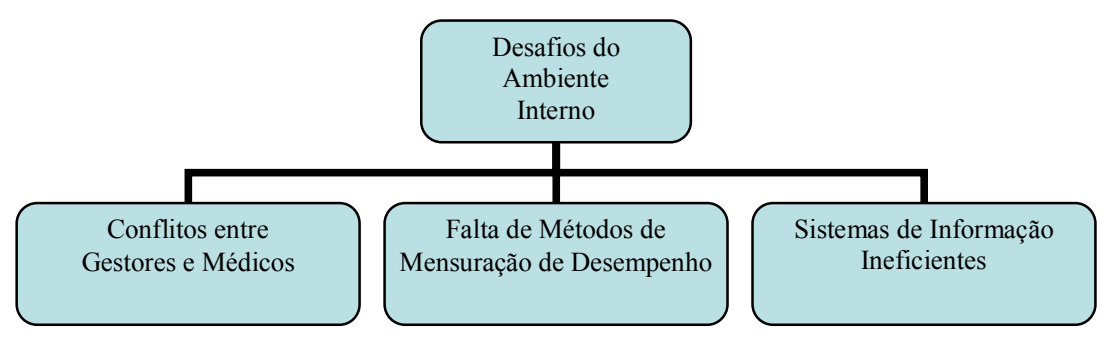

Fonte: elaborado pelo autor.

Exclusivamente para as organizações privadas de saúde, Martins (2002) destaca também a importância do equilíbrio hospitalar (no tocante a seus custos e ganhos) e da análise constante deste equilíbrio de custos, a fim de facilitar a tomada de decisões por parte de seus gestores. $\mathrm{O}$ conceito de equilíbrio hospitalar em face dos custos, segundo o mencionado professor

[...] implica o nível da produção médica em que o hospital não realiza lucro nem sofre prejuízo. A análise do ponto de equilíbrio não se constitui em jornada segura para o lucro, mas em instrumento valioso na descoberta do potencial de lucro; revela a que nível de produção médica o custo e a receita hospitalar equilibram-se. Geralmente, se apresenta de forma gráfica, porque, além de mostrar o nível da produção médica em que não ocorre lucro nem prejuízo, aponta as possibilidades relacionadas com modificações nos custos e receitas hospitalares (MARTINS, 2002, p. 127).

Por derradeiro, pode-se dizer que a "necessidade de gerir organizações profissionais, entre as quais se situam as de saúde, obriga a pensar os termos comunicação e negociação como elementos decisivos de um determinado modelo de gestão" (RIVERA, 2003, p. 219).

\subsection{Gerenciamento de Resíduos Sólidos}

Antes de se falar em resíduos sólidos, é necessário que se façam algumas colocações sobre um conceito maior que engloba o próprio conceito de resíduos (o qual, por sua vez, para alguns autores não especializados - de acordo com Philippi Jr. (2004, reimp. 2006) - chega até mesmo ser utilizado como sinônimo do conceito de lixo): a poluição.

Sobre a poluição, Seiffert (2007) levanta interessante discussão acerca de qual seria o nível adequado de sua produção, para que nem as atividades produtivas venham a ser prejudicadas em termos de viabilidade (e conseqüente elevação do nível de desemprego de uma dada localidade), e nem o equilíbrio ambiental de todo o meio que circunda a unidade poluidora seja prejudicado, de forma a comprometer sua própria continuidade natural. Para ela 
O nível ótimo de poluição reside no fato de que um instrumento de gestão ambiental deve ser estruturado de modo a considerar um equilíbrio entre os prejuízos e os benefícios tanto na ótica privada como na ótica social, de modo a evitar que a ótica social seja desfavorecida em relação à privada e vice-versa. (SEIFFERT, 2007, p. 79).

Derisio (1992), ao tratar do tema poluição (se reportando mais especificamente ao problema das águas), destaca a existência de quatro principais categorias:

a) A poluição natural, que não é associada à atividade humana e pode ser ocasionada por chuvas, escoamento de terras, erosão natural, salinização e pela decomposição de vegetais e animais mortos;

b) A poluição industrial, totalmente associada às atividades humanas, constituindo-se numa das principais fontes poluidoras das águas, do ar e geradoras de resíduos que contaminam o meio ambiente;

c) A poluição urbana, também associada às atividades humanas e à vida nas cidades, com destaque para a geração de resíduos domésticos e de esgotos, os quais, em partes significativas, acabam sendo lançados direta ou indiretamente, sem tratamento, nos corpos d'água;

d) A poluição agropastoril, decorrente de atividades ligadas à agricultura e pecuária, que degradam o meio ambiente através da derrubada das matas nativas para pasto, além do uso abusivo de fertilizantes e geração de resíduos por meio dos excrementos dos próprios animais.

Por outro lado, como a poluição é um conceito muito maior que o próprio conceito de resíduo sólido, importante dar destaque também aos principais poluentes atmosféricos (não sólidos) cujos destaques encontram-se no quadro 1.

\begin{tabular}{|c|l|l|}
\hline \multicolumn{2}{|c|}{ Principais Fontes de Poluição e Principais Poluentes Atmosféricos } \\
\hline \multicolumn{2}{|c|}{ Fontes } & \multicolumn{1}{c|}{ Poluentes } \\
\hline & Combustão & Material Particulado \\
E & & $\begin{array}{l}\text { Dióxido de Enxofre e Trióxido de } \\
\text { Enxofre }\end{array}$ \\
$\mathrm{s}$ & & Enxofre \\
$\mathrm{t}$ & & Monóxido de Carbono, \\
$\mathrm{a}$ & & Hidrocarbonetos e Óxidos de \\
$\mathrm{c}$ & & Nitrogênio \\
$\mathrm{i}$ & Processo Industrial & Material Particulado (fumos, poeiras, \\
$\mathrm{o}$ & & névoas) \\
\hline
\end{tabular}




\begin{tabular}{|c|c|c|}
\hline $\begin{array}{l}\mathrm{n} \\
\mathrm{a}\end{array}$ & & $\begin{array}{l}\text { Gases, Hidrocarbonetos, Mercaptanas, } \\
\text { HF e Outros }\end{array}$ \\
\hline $\begin{array}{l}\mathrm{r} \\
\mathrm{i}\end{array}$ & Queima de Resíduos Sólidos & $\begin{array}{l}\text { Material Particulado } \\
\text { Gases (Ex: HCI) }\end{array}$ \\
\hline $\begin{array}{l}\mathrm{a} \\
\mathrm{s}\end{array}$ & Outros & Hidrocarbonetos, Material Particulado \\
\hline $\begin{array}{l}\text { M } \\
\text { ó } \\
\mathrm{V} \\
\mathrm{e} \\
\mathrm{i} \\
\mathrm{s}\end{array}$ & $\begin{array}{l}\text { Veículos (Gasolina, Diesel, } \\
\text { Álcool), Aviões, Motocicletas, } \\
\text { Barcos, Locomotivas, Etc. }\end{array}$ & $\begin{array}{l}\text { Material Particulado, Monóxido de } \\
\text { Carbono, Óxidos de Enxofre, Óxidos } \\
\text { de Nitrogênio, Hidrocarbonetos, } \\
\text { Aldeídos, Ácidos Orgânicos }\end{array}$ \\
\hline \multicolumn{2}{|r|}{ Naturais } & $\begin{array}{l}\text { Material Particulado - Poeiras, Gases } \\
\text { (CO, NO, Etc.), Hidrocarbonetos }\end{array}$ \\
\hline \multicolumn{2}{|c|}{$\begin{array}{l}\text { Reações Químicas na Atmosfera. Ex: } \\
\text { Hidrocarbonetos + Óxidos de nitrogênio (luz solar) }\end{array}$} & $\begin{array}{l}\text { Poluentes Secundários - Ozônio, } \\
\text { Aldeídos, Ácidos Orgânicos, Nitratos, } \\
\text { Orgânicos, Aerossol Fotoquímico, } \\
\text { Etc. }\end{array}$ \\
\hline
\end{tabular}

Fonte: DERISIO (1992, p. 124).

\section{Quadro 1: Principais Fontes de Poluição e Principais Poluentes Atmosféricos}

Feitas estas necessárias considerações iniciais sobre a poluição em geral, considera-se que, quando se fala em gerenciamento de resíduos sólidos, não se pressupõe a existência, unicamente, dos resíduos produzidos por hospitais, laboratórios, clínicas e instituições prestadoras de serviços de saúde em geral, uma vez que as normas atualmente em vigor reconhecem quatro categorias distintas de resíduos, sendo os RSS apenas uma delas.

Historicamente, o gerenciamento dos resíduos sólidos nas áreas urbanas se baseou na coleta $^{7}$ (efetuada via de regra pelas administrações municipais ou empresas por elas terceirizadas) e por seu afastamento dos grandes centros, o que, de acordo com Philippi Jr. (2005, reimp. 2008) gerava a sensação, na população, de que os mesmos simplesmente desapareciam de sua vista, deixando, portanto, de continuarem a se consistir num problema.

\footnotetext{
${ }^{7}$ Sobre o custo do transporte urbano do lixo, Aguiar, Ferraz e Schalch (1992), através da aplicação de um modelo analítico chamado TRANSLIX (nome obtido com a junção das palavras "trans", de transporte, e "lix", de lixo), avaliou a influência do porte e da forma geográfica da cidade, em interessante artigo publicado na Revista de Transporte e Tecnologia de Campina Grande. Os resultados obtidos pelos autores demonstraram que o custo médio do serviço de coleta de lixo cresce com o aumento do porte da cidade, bem como que o custo da coleta diminui quando a densidade populacional aumenta e que, quanto mais alongadas as cidades, maior é o custo médio da coleta de lixo (concluindo daí que o formato urbano mais econômico quando se fala em coleta de lixo é o quadrado).
} 
Nesta linha de raciocínio, é indubitável que, com o progresso científico e tecnológico e o crescimento vertiginoso da população mundial nos últimos dois séculos, intensificou-se também e demasiadamente a poluição e degradação ambiental e, por óbvio, a produção de resíduos e rejeitos sólidos pelas sociedades humanas.

O gráfico abaixo demonstra a evolução do crescimento da população mundial, a qual ocorreu vertiginosamente a partir do Século XIX (figura 1).

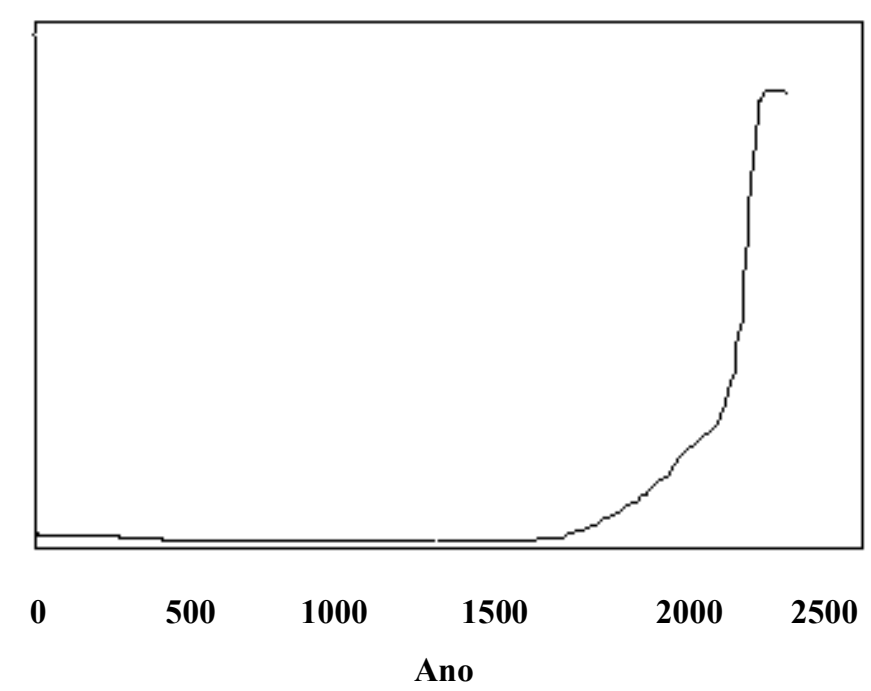

Fonte: PHILIPPI Jr. (2004, reimp. 2006, p. 157)

Figura 1: Evolução do Crescimento da População Mundial (em bilhões de pessoas)

Philippi Jr. (2004, reimp. 2006) destaca que o homem tem uma capacidade que o torna exclusivo dentre todos os agentes (naturais e não naturais) com poder de desequilibrar a natureza, qual seja, a de transformar materiais em larga escala e tornar quimicamente estáveis substâncias e produtos. Por este motivo, para o renomado autor, o ser humano coloca na natureza produtos em formatos e composições que o meio natural não conhece e que, por este motivo, não tem capacidade de absorção ou, ainda que o tenha, esta se dá em prazos demasiadamente longos.

A tabela 1 demonstra o tempo levado para alguns materiais se decomporem na natureza. 
Tabela 1 - Tempo de degradação de materiais

\begin{tabular}{ll}
\hline Material & Tempo de Degradação \\
\hline Aço & Mais de 100 anos \\
Alumínio & 200 a 500 anos \\
Cerâmica & Indeterminado \\
Chicletes & 5 anos \\
Cordas de nylon & 30 anos \\
Embalagens longa vida & Até 100 anos (alumínio) \\
Embalagem pet & Mais de 100 anos \\
Esponjas & Indeterminado \\
Filtros de cigarro & 5 anos \\
Isopor & Indeterminado \\
Louças & Indeterminado \\
Luvas de borracha & Indeterminado \\
Metais (componentes de equipamentos) & Cerca de 450 anos \\
Papel e papelão & Cerca de 6 meses \\
Plásticos (embalagens e equipamentos) & Até 450 anos \\
Pneus & Indeterminado \\
Sacos e sacolas plásticas & Mais de 100 anos \\
Vidros & Indeterminado \\
\hline
\end{tabular}

Fontes: Derisio (1992) / Philippi Jr. (2004, reimp. 2006).

De acordo com uma das obras organizadas pelo professor Philippi Jr.

A produção de resíduos sólidos faz parte do cotidiano do ser humano. Não se pode imaginar um modo de vida que não gere resíduos sólidos. Devido ao aumento da população humana, à concentração dessa população em centros urbanos, à forma e ao ritmo da ocupação desses espaços e ao modo de vida com base na produção e consumo cada vez mais rápidos de bens, os problemas causados por esses resíduos tendem a se tornar mais visíveis. Atualmente, a visão da sociedade sobre a questão dos resíduos sólidos tem incorporado novos elementos, notando-se avanços significativos na importância que se confere à questão. Conseqüentemente, cada vez mais espaço na mídia e nas discussões políticas é ocupado pelos problemas associados aos resíduos sólidos. (PHILIPPI JR, 2005, reimp. 2008, p. 268-269).

A Associação Brasileira de Normas Técnicas (ABNT) conceitua os resíduos sólidos da seguinte forma: 
[...] resíduos nos estados sólido e semi-sólido, que resultam de atividades da comunidade de origem: industrial, doméstica, comercial, agrícola, de serviços e de varrição. Ficam incluídos nesta definição os lodos provenientes dos sistemas de tratamento de água, aqueles gerados em equipamentos e instalações de controle de poluição, bem como determinados líquidos cujas particularidades tornem inviável o lançamento na rede pública de esgotos ou corpos de água, ou exijam para isso soluções técnica e economicamente inviáveis face à melhor tecnologia prática disponível. (ABNT, NBR 10004:2004)

Transcrita esta definição, considera-se, como já exposto, que os resíduos sólidos são classificados em quatro tipos distintos, cada um agrupando determinada categoria de resíduos, e possuindo normas reguladoras próprias. São eles:

a)

Os resíduos sólidos domiciliares - RSD - são divididos em sete grupos distintos, quais seja, alumínios, plásticos (polímeros), folha de flandes, vidros, papel e papelão, embalagens longa-vida e matéria orgânica (também chamada de material facilmente biodegradável), esta última correspondendo, no Brasil, por cerca de $60 \%$ do lixo produzido no grupo ao qual pertence. A Resolução no 005/93 do CONAMA (1993) dispõe sobre os RSD.

b) Os resíduos dos serviços de saúde (RSS) - consistem-se no objeto de estudo do presente trabalho e serão tratados especificamente no próximo subcapítulo. Pode-se dizer que várias normas disciplinam os RSS, tais como: a ABNT 12.807; a ABNT 12.808; a ABNT 12.809; a ABNT 12.810 e a RDC 306/04 da ANVISA.

c) Os resíduos de construção e demolição $(\mathrm{RCD})$ - que compreendem restos de madeira, cimento, ferrolhos, ladrilhos, tijolos, entulho, etc. Sua regulamentação passa pela Resolução no 307/2002 da CONAMA (2002), a qual os designa por RCC - resíduos de construção civil.

d) Os resíduos sólidos industriais - RSI - dos quais dispõe, de maneira detalhada, a resolução $n^{\circ} 313 / 02$ da CONAMA (2002), além das próprias NBR 10.004:2004, 10.005:2004, 10.006:2004 e 10.007:2004, todas da ABNT.

Didaticamente, a classificação retro pode ser lançada na forma de diagrama (do tipo fluxograma), como pode ser visto na figura 2 . 


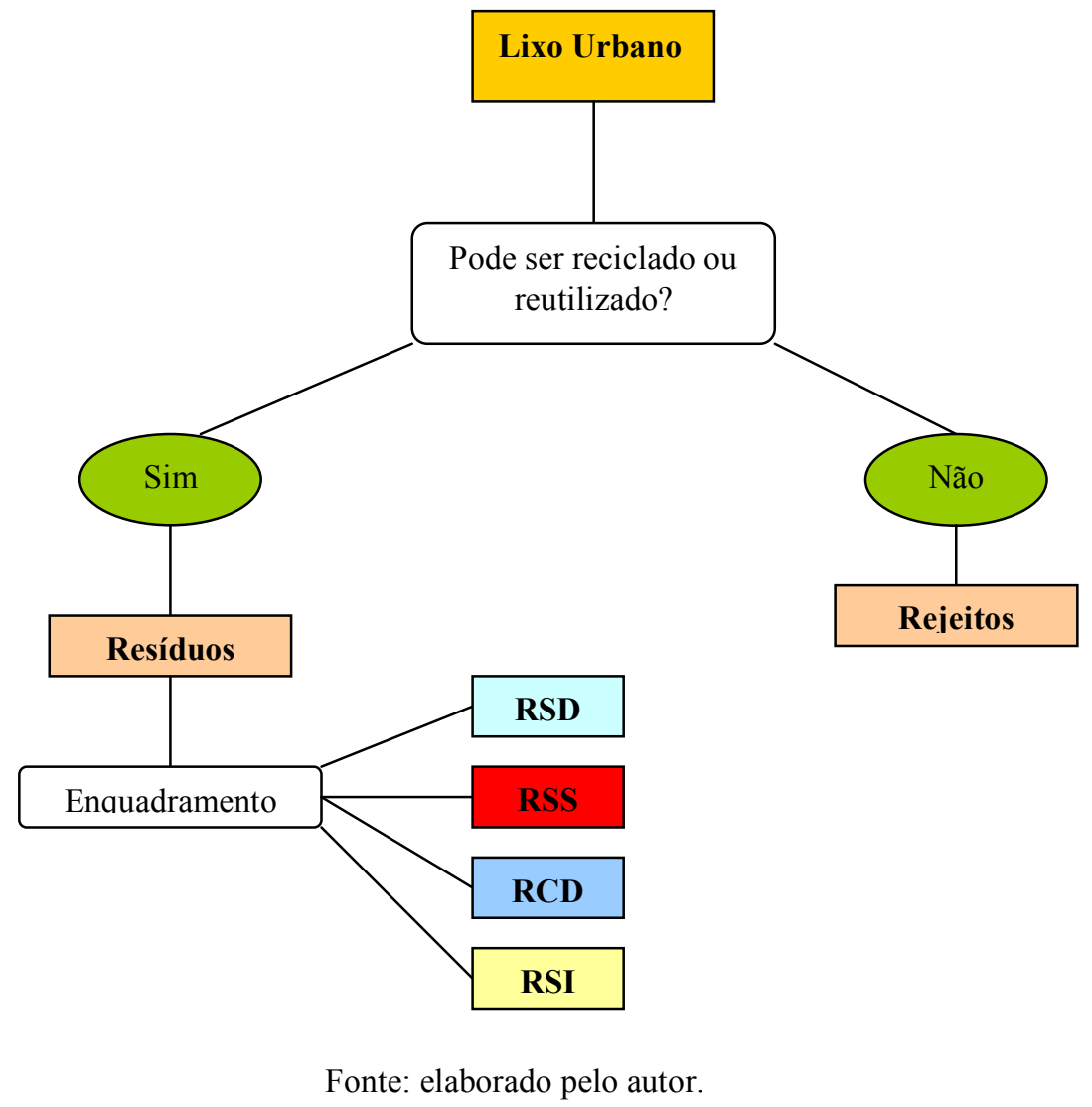

Figura 2: Classificação dos resíduos sólidos urbanos.

Importante destacar que, além da classificação já exposta (normalmente aceita pelas principais obras que tratam do gerenciamento de resíduos sólidos), alguns autores consideram a existência de uma quinta categoria de resíduos urbanos, que não se enquadrariam em nenhuma das quatro categorias mencionadas. Essa quinta categoria seria composta pelos resíduos de varrição urbana, poda de árvores e capina de terrenos.

Por outro lado, conforme se verifica do próprio diagrama da figura 2, existem alguns tipos de resíduos que não se enquadram em nenhuma das categorias já mencionadas, por não possuírem, com a tecnologia atualmente disponível no mundo, nenhuma forma de tratamento, de reciclagem ou de reutilização, sendo normalmente enterrados em aterros sanitários. São exemplos deste tipo de resíduos: pneus usados, lâmpadas fluorescentes queimadas, pilhas e baterias, etc. Justamente pelo fato de não se enquadrarem em nenhum grupo ou categoria de resíduo, considera-se que a designação correta para os mesmos seria "rejeitos". 
Outra forma de classificação dos resíduos sólidos urbanos é feita pela NBR 10.004: 2004 da ABNT (2004). Através desta norma, considera-se a existência de apenas duas classes de resíduos, a saber: a) Resíduos Classe I (Perigosos) e b) Resíduos Classe II (Não Perigosos); sendo certo que este último tipo se subdividiria em mais dois grupos, quais sejam: a') Resíduos Classe II A (Não Inertes) e b') Resíduos Classe II B (Inertes).

Para Philippi Jr. (2005, reimp. 2008) independentemente do tipo de classificação que receba o resíduo sólido urbano gerado (domiciliares, industriais, de serviços de saúde, de construção ou demolição e outros), ou do grupo ao qual ele pertença, seu gerenciamento correto deve ser dividido, grosso modo, em etapas semelhantes (contendo cada uma seus preceitos e cuidados próprios), constituídas, basicamente, do: a) acondicionamento e armazenamento; b) coleta e transporte e c) tratamento e disposição final.

Quanto ao aspecto jurídico da questão, Fiorillo (2008, p. 215) ensina que "o gerenciamento dos resíduos sólidos não se submete a um regime jurídico único, porquanto varia de acordo com a localidade onde são gerados e com o seu conteúdo".

Sob o ponto de vista da legislação aplicável, Jacobi (2006, p. 163) entende que

[...] ainda não estão sendo utilizados instrumentos efetivos de inserção. Os convênios entre prefeituras e cooperativas de catadores quando utilizados como instrumentos de parceria são frágeis e ineficientes. Ainda na perspectiva da sustentabilidade dos programas e das cooperativas, e apesar dos discursos das prefeituras no sentido de apoiar a autonomia das cooperativas, ainda encontramos uma tendência geral de tutelar e capitalizar a atuação das cooperativas/associações. No geral, a prefeitura arca com o aluguel dos galpões ou as cooperativas ocupam áreas municipais e dependem do poder público.

Não obstante, o artigo $3^{\circ}$, inciso III, da Lei no 6.938/81 (que instituiu a Política Nacional do Meio Ambiente) (BRASIL, 1981), prevê expressamente que o lixo urbano possui a natureza jurídica de poluente ${ }^{8}$. Por este motivo, Fiorillo (2008) entende que o lixo urbano, desde o momento em que é produzido, já possui a natureza jurídica de poluente, porque "assumindo o papel de resíduo urbano, deverá ser submetido a um processo de tratamento que, por si só,

\footnotetext{
${ }^{8}$ É importante que se destaque, também, outras legislações que estejam, direta ou indiretamente, relacionadas à questão da poluição no Brasil, e que contribuíram, de alguma forma, para equacionar ou solucionar problemas inerentes à geração de resíduos. Por exemplo, saliente-se a Lei $n^{\circ}$ 5.318/67, que instituiu a Política Nacional de Saneamento no país ainda na década de 1960 do século passado, e criou o Conselho Nacional de Saneamento. A título de atos administrativos com valor normativo, ressalte-se as resoluções SMA 22 e SMA 50 (ambas do ano de 2007), editadas pela Secretaria do Meio Ambiente do Estado de São Paulo (um dos entes pioneiros nas questões ambientais no país), as quais, respectivamente, unificam os procedimentos de licenciamento ambiental no estado e instituem programas para diminuir a produção de lixo.
} 
constitui, mediata ou imediatamente, forma de degradação ambiental.” (FIORILLO, 2008, p. 211).

No tocante à seriedade e ao caráter emergencial com que o assunto da geração de lixo (resíduos sólidos urbanos) tem que ser tratado, quer pelos formadores de opinião, quer pelas autoridades públicas em geral, Jacobi (2006, p. 162) destaca que a

[...] questão da geração e disposição dos resíduos sólidos em uma metrópole, como um dos mais sérios problemas de gestão ambiental urbana, a tentativa de equacionar esse problema através da criação de nichos de trabalho para segmentos da população de baixa renda pode-se revelar frutífera, desde que as diversas entidades envolvidas no processo atentem para as necessidades e dinâmicas dos catadores/recicladores, que vêm, aos poucos, conquistando uma identidade própria, e vislumbrando algumas perspectivas de uma ocupação sustentável em suas trajetórias específicas.

Quanto ao processo de gerenciamento dos resíduos sólidos propriamente dito, Philippi Jr. (2005, reimp. 2008) destaca a busca das mais diversas alternativas para equacionar, solucionar ou, ao menos, amenizar o problema, alternativas estas que envolvam sistemas de gestão integrada, onde haja aplicação simultânea (pois sem isso essas medidas seriam ineficazes) de medidas de redução de geração na fonte, minimização dos resíduos por meio da implantação de formas diferentes de tratamento, consideradas as peculiaridades locais, políticas de educação ambiental, dentre outras.

Referido autor ainda destaca a importância dos chamados "quatro R's" também para a minimização da produção destes resíduos. Estes quatro R's, seriam, na verdade, as iniciais das palavras "reduzir", "reutilizar", "reciclar" e "recuperar energia" (para alguns autores, ao invés deste último conceito, de "recuperação de energia", o mais correto seria "repensar" - no tocante aos atuais modos de produção e modelos de desenvolvimento), cuja aplicação concomitante poderia gerar vários benefícios, dentre eles a economia, quer na incineração de resíduos, quer na utilização de áreas para criação e ampliação de aterros sanitários.

\footnotetext{
No entanto, estes programas ainda apresentam uma grande fragilidade em virtude de vários fatores: do aumento de catadores avulsos que para garantir a sua sobrevivência competem com os organizados, problemas de ordem organizacional, a dependência dos grupos de catadores em relação ao poder público, e a não consolidação da inserção formal no sistema de limpeza pública, o que acarreta a descontinuidade e a fragilidade dos programas. (JACOBI, 2006, p. 162-163).
}

Por fim, há de ser considerada ainda, a questão dos rejeitos (resíduos para os quais não existe ainda a possibilidade de tratamento, reciclagem ou reutilização), cuja geração só poderá ser 
reduzida através do desenvolvimento de novas tecnologias que passem a possibilitar, de alguma forma, o seu reaproveitamento.

\subsection{Resíduos de Serviços de Saúde - RSS}

Como já visto, os resíduos dos serviços de saúde (RSS) são, na classificação usual, um dos quatro tipos de resíduos urbanos, juntamente com os resíduos sólidos domésticos (RSD), resíduos de construção e demolição $(\mathrm{RCD})$ e resíduos sólidos industriais (RSI), cada grupo contendo sua regulamentação própria.

Historicamente, no Brasil,

[...] os resíduos gerados nos serviços de saúde ficaram sem uma classificação legal específica até o início da década de 1990. Em 1989, o Centro de Vigilância Sanitária (CVS) da Secretaria de Estado da Saúde de São Paulo, lançou um guia para gerenciamento desses resíduos (ss 1989), que os classificava em três categorias: infectantes, especiais (incluindo os farmacêuticos, radioativos e químicos perigosos) e comuns. No entanto, esse manual tinha apenas efeito técnico e não legal, embora tenha representado um importante instrumento de orientação para os serviços de saúde. (PHILIPPI JR, 2005, reimp. 2008, p. 325).

No início da década de 1990, a Associação Brasileira de Normas Técnicas (ABNT) passou a editar uma série de normas, tais como a NBR 12.808:1993 (ABNT, 1993), para tratar de assuntos ligados aos RSS, inclusive classificando-os (seguindo assim, a linha pioneira da Secretaria de Estado da Saúde de São Paulo, como bem ensinou Philippi Jr.).

Outrossim, a resolução n ${ }^{0}$ 05/93 do CONAMA (1993), acabou por representar a primeira norma legal que classificou os RSS em quatro grupos distintos, a saber:

a) Grupo A (Materiais Infectantes): eram aqueles que apresentavam risco potencial à saúde pública e ao meio ambiente, como, por exemplo, o sangue, substâncias hemoderivadas, secreções, fluidos orgânicos humanos e de animais, meios de cultura, etc.

b) Grupo B (Resíduos Químicos): consistiam-se em materiais que também apresentavam risco potencial à saúde pública e ao meio ambiente, mas de origem diversa daqueles pertencentes ao Grupo A, tais como os resíduos farmacêuticos, os medicamentos vencidos, além de outros materiais que também se enquadravam no disposto na NBR 10.004:2004 da ABNT (materiais tóxicos, corrosivos, etc). 
Grupo C (Materiais Radioativos): grupo constituído por rejeitos radiativos, como por exemplo, materiais contaminados com radionuclídeos, provenientes de laboratórios de análises clínicas e serviços de medicina nuclear, dentre outros.

d) Grupo D (Resíduos Comuns): eram aqueles materiais, produzidos por instituições prestadoras de serviços de saúde, que não se enquadravam nos demais grupos.

Posteriormente, novas normas versando sobre o tema foram editadas, tais como a resolução $n^{\circ}$ 283/2001 (CONAMA, 2001) e, posteriormente, a Resolução $n^{0} 358 / 2005$ (CONAMA, 2005), prevalecendo hoje uma classificação dos RSS em grupos distintos, de acordo com o que prevê a RDC 306/2004, editada pela ANVISA - Agência Nacional de Vigilância Sanitária.

Quanto à ANVISA, o intróito da RDC 306/04 (atualmente em vigor), assim dispõe:

\begin{abstract}
A Diretoria Colegiada da Agência Nacional de Vigilância Sanitária, no uso da atribuição que lhe confere o art. 11, inciso IV, do Regulamento da ANVISA aprovado pelo Decreto $\mathrm{n}^{\circ} 3.029$, de 16 de abril de 1999 c/c o Art. 111, inciso I, alínea "b", parágrafo $1^{\circ}$ do Regimento Interno aprovado pela Portaria $n^{\circ} 593$, de 25 de agosto de 2000, publicada no DOU de 22 de dezembro de 2000, em reunião realizada em 6 de dezembro de 2004, considerando as atribuições contidas nos Art. $6^{\circ}$, Art. $7^{\circ}$., inciso III e Art. $8^{\circ}$ da Lei 9782 , de 26 de janeiro de 1999; considerando a necessidade de aprimoramento, atualização e complementação dos procedimentos contidos na Resolução RDC 33, de 25 de fevereiro de 2003, relativos ao gerenciamento dos resíduos gerados nos serviços de saúde - RSS, com vistas a preservar a saúde pública e a qualidade do meio ambiente considerando os princípios da biossegurança de empregar medidas técnicas, administrativas e normativas para prevenir acidentes, preservando a saúde pública e o meio ambiente; considerando que os serviços de saúde são os responsáveis pelo correto gerenciamento de todos os RSS por eles gerados, atendendo às normas e exigências legais, desde o momento de sua geração até a sua destinação final; considerando que a segregação dos RSS, no momento e local de sua geração, permite reduzir o volume de resíduos perigosos e a incidência de acidentes ocupacionais dentre outros benefícios à saúde pública e ao meio ambiente; considerando a necessidade de disponibilizar informações técnicas aos estabelecimentos de saúde, assim como aos órgãos de vigilância sanitária, sobre as técnicas adequadas de manejo dos RSS, seu gerenciamento e fiscalização; adota a seguinte Resolução da Diretoria Colegiada e eu, Diretor-Presidente, determino a sua publicação [...]
\end{abstract}

Com efeito, quanto à classificação dos resíduos de serviços de saúde disposta pela RDC 306/2004 da ANVISA, ela acabou por instituir um quinto grupo, aumentando assim a distinção antes efetuada pela resolução $n^{\circ}$ 05/93 do CONAMA:

- GRUPO A: potencialmente infectantes;

- GRUPO B: químicos; 
- GRUPO C: radioativos;

- GRUPO D: comuns;

- GRUPO E: perfurocortantes.

De maneira sucinta, pode-se dizer que os resíduos dos serviços de saúde - RSS - são aqueles gerados em hospitais, clínicas, ambulatórios e instituições similares, sendo que os mesmos têm em comum o fato de estarem potencialmente contaminados com agentes patogênicos. ${ }^{9}$ Neste mesmo sentido, ressalte-se o entendimento da obra do professor Philippi Jr. (2005, reimp. 2008).

Interessante destacar também que, em algumas normas da ABNT, os resíduos dos serviços de saúde recebem a denominação de "resíduos hospitalares".

Esta denominação também é utilizada por alguns dos principais autores da área de meio ambiente. Por exemplo, ao conceituar os resíduos dos serviços de saúde, Fiorillo (2008) também os denomina como resíduos hospitalares.

Para o autor, esses resíduos (provenientes todos de estabelecimentos que prestam serviços de saúde),

[...] constituem os grandes geradores de problemas à população. Estão compreendidos como resíduos hospitalares: sangue e hemoderivados, excreções, secreções, restos oriundos de áreas de isolamento, fetos e peças anatômicas, bem como objetos perfurantes ou cortantes capazes de causar punctura ou corte. Tendo em vista os problemas trazidos pelos resíduos hospitalares, bem como os riscos de contaminação que representam, a Associação Brasileira de Normas Técnicas - ABNT estabelece uma série de normas para conceituar e denominar os resíduos gerados nos hospitais, laboratórios, clínicas e demais serviços de saúde. Busca-se com isso facilitar a classificação, a separação e o destino do material, a partir do seu conhecimento. (FIORILLO, 2008, p. 214).

Por outro lado, também é importante destacar que nem todos os resíduos produzidos em unidades prestadoras de serviços de saúde, hospitais, laboratórios e clínicas são necessariamente considerados RSS, havendo inclusive a possibilidade de coleta seletiva de resíduos dentro destas organizações (por exemplo, separando-se papéis, vidros, metais e plásticos que não tiveram contato com nenhum material biologicamente perigoso, radioativo ou agente patogênico), bem como da implantação de caixas de compostagem de material orgânico que não ofereça risco à saúde pública.

\footnotetext{
9 “Conforme dados do IBGE (2000), a produção de resíduos sólidos no Brasil é de 228.413 toneladas/dia. Os resíduos de serviços de saúde respondem, segundo estimativa da Anvisa (2003c), por 1\% deste total. Calculando estes dados acima, verifica-se que os resíduos de serviços de saúde perfazem, no Brasil, uma projeção de produção da ordem de 2.284 toneladas/dia". (SOUZA, p. 11).
} 


\title{
De acordo com a ABNT
}

\begin{abstract}
A periculosidade de um resíduo relaciona-se às suas propriedades físico-químicas e infecto-contagiosas pelo risco à saúde pública, provocando ou acentuando, de forma significativa, a mortalidade ou incidência de doenças e riscos ao ambiente, quando o resíduo é manuseado ou destinado de forma inadequada (NBR 10.004:2004).
\end{abstract}

Retomando a questão de sua classificação, tem-se que, atualmente, referidos resíduos (RSS) continuam divididos em quatro grupos distintos, mas não mais obedecendo aos critérios da resolução $n^{\circ}$ 005/93 da CONAMA, e sim conforme preconiza a RDC 306/2004 da ANVISA, que os distingue conforme os riscos que representem à saúde humana e ao meio ambiente.

Neste sentido, transcreve-se a divisão válida nos dias de hoje com relação aos RSS:

[...] O Grupo A é identificado pelo símbolo de substância infectante constante na NBR7500 da ABNT, com rótulos de fundo branco, desenho e contornos pretos.

[...] O Grupo B é identificado através do símbolo de risco associado, de acordo com a NBR 7500 da ABNT e com discriminação de substância química e frases de risco.

[...] O Grupo C é representado pelo símbolo internacional de presença de radiação ionizante (trifólio de cor magenta) em rótulos de fundo amarelo e contornos pretos, acrescido da expressão: REJEITO RADIOATIVO.

[...] O Grupo E é identificado pelo símbolo de substância infectante constante na NBR7500 da ABNT, com rótulos de fundo branco, desenho e contornos pretos, acrescido da inscrição de RESÍDUO PERFUROCORTANTE, indicando o risco que apresenta o resíduo (07.12.2004).

É certo que a classificação retro foi desenvolvida com o intuito de englobar o maior número possível dos tipos de resíduos que possam ser gerados ou produzidos pelas organizações que prestam serviços na área de saúde. Casos problemáticos de classificação também existem, assim como a figura dos rejeitos (resíduos sem nenhuma forma de aproveitamento, tratamento, reutilização ou reciclagem), da mesma forma que ocorre com os demais grupos de resíduos urbanos.

Encerrando as considerações, vale registrar o pensamento de Jacobi (2006), para quem, não existe nenhum outro caso melhor para se estabelecer vínculos entre as atividades humanas e o meio ambiente que as circundam, do que os métodos que a própria sociedade que pratica estas atividades se utiliza para administrar os resíduos que ela mesma acaba por produzir.

\subsection{Legislação e Normatividade Relacionadas aos RSS}

É sabido que, nos últimos vinte anos, os problemas ambientais ocuparam cada vez mais espaço na opinião pública, devido à importância e à gravidade dos mesmos. Assim, a busca por 
conceitos como qualidade de vida, sustentabilidade, responsabilidade ambiental e meio ambiente saudável, começou a se materializar também na legislação nacional.

\begin{abstract}
A presença da fórmula qualidade de vida, finalidade máxima da implementação dos preceitos normativos do direito ambiental, surgiu como complemento necessário ao sentido de que anteriormente lhe era dado pelas teorias econômicas preocupadas com a consecução do bem-estar - encontradas sustentando as normas da ordem econômica constitucional brasileira, dentro da afirmação de que esta ordem tem por fim assegurar a todos existência digna, conforme os ditames da justiça social (art. 170). A inserção de tal expressão no direto ambiental brasileiro acaba por denunciar a busca por um aspecto qualitativo, depois das decepções resultantes da adoção de um sentido unicamente quantitativo para designar qualidade de vida, traduzida que era apenas por conquistas materiais. O alargamento do sentido da expressão "qualidade de vida", além de acrescentar esta necessária perspectiva de bem-estar relativo à saúde física e psíquica, referindo-se inclusive ao direito do homem fruir de um ar puro e de uma bela paisagem, vinca o fato de que o meio ambiente não diz respeito à natureza isolada, estática, porém integrada á vida do homem social nos aspectos relacionados à produção, ao trabalho como também concernente ao seu lazer. (DERANI, 2008, p. 58).
\end{abstract}

O principal reflexo dessa nova maneira de discutir e de se encarar o meio ambiente como algo imprescindível para a sobrevivência da própria sociedade humana, possui três grandes marcos no Brasil: o primeiro, com a edição da lei $n^{\circ}$ 5.318, de 26 de setembro de 1967 (que instituiu a Política Nacional de Saneamento) (BRASIL, 1967); o segundo com a promulgação da lei $\mathrm{n}^{\circ}$ 6.938, em 31 de agosto de 1981 (que instituiu aquilo que se convencionou chamar de Política Nacional do Meio Ambiente) (BRASIL, 1981); e o terceiro, com o advento da atual Constituição Federal de 1988 (a qual dedicou todo um capítulo à questão do meio ambiente) (BRASIL, 1988). ${ }^{10}$

Especificamente com relação à lei no 6.938/81, ressalte-se que a mesma, em seu artigo $1^{\circ}$, criou o Sisnama - Sistema Nacional do Meio Ambiente, além de instituir (com a nova redação que lhe fora dada pela lei no 8.028, de 1990), o Cadastro de Defesa Ambiental.

Já no seu artigo $2^{\circ}$, traçou as diretrizes do que viria a ser a Política Nacional do Meio Ambiente, in verbis:

Art $2^{\circ}$ - A Política Nacional do Meio Ambiente tem por objetivo a preservação, melhoria e recuperação da qualidade ambiental propícia à vida, visando assegurar, no País, condições ao desenvolvimento sócio-econômico, aos interesses da segurança nacional e à proteção da dignidade da vida humana, atendidos os seguintes princípios:

\footnotetext{
${ }^{10}$ Isso, claro, sem tirar o mérito de várias outras leis e normas correlatas, que foram editadas ao longo dos últimos anos, cada qual fornecendo algum tipo de contribuição às chamadas questões ambientais.
} 


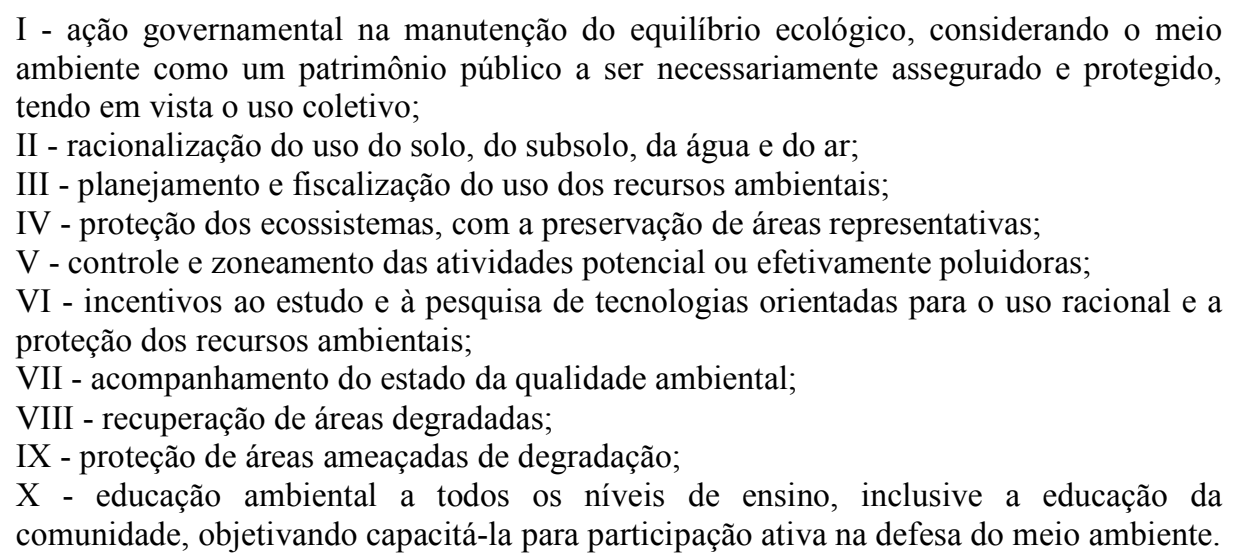

Referida lei, que provavelmente foi inspirada nas legislações anteriores, como a Lei da Política Nacional de Saneamento, também pode ter servido, por sua vez, de inspiração para a Assembléia Nacional Constituinte que, no ano de 1988, promulgou a atual Constituição da República Federativa do Brasil. No corpo da atual Constituição Federal, mais especificamente em seu Título VIII (intitulado Da Ordem Social), Capítulo VI, existe um artigo 225, que contém sete incisos e seis parágrafos, todos eles atinentes à matéria ambiental.

Reza o caput do aludido artigo o que segue:

Art. 225. Todos têm direito ao meio ambiente ecologicamente equilibrado, bem de uso comum do povo e essencial à sadia qualidade de vida, impondo-se ao Poder Público e à coletividade o dever de defendê-lo e preservá-lo para as presentes e futuras gerações.

Não obstante, atualmente, toda uma série de entidades públicas, ministérios, autarquias, agências reguladoras do governo e secretarias de um modo geral, criam, editam, baixam e publicam normas inerentes a assuntos diversos ligados todos à questão ambiental.

Desta forma, como também ocorre com os demais temas relativos ao meio ambiente, não existe, no Brasil, uma legislação padronizada a nível federal, estadual e municipal, relativamente à questão da gestão dos RSS, sendo certo que, além da Constituição Federal prever, em seu artigo 24, a competência concorrente dos entes federativos (União, Estados e Municípios) para legislar sobre matérias relativas ao meio ambiente, ainda existe o problema dos órgãos os mais variados, ligados à administração pública direta ou indireta (como, por exemplo, o CONAMA - ligado à Secretaria Nacional do Meio Ambiente -, a ANVISA - ligada à Secretaria Nacional da Saúde -, a ABNT, o IPEN, a CETESB/SP - esta atuando exclusivamente no Estado de São Paulo-, dentre outros), expedirem atos normativos relativos à questões ambientais, vislumbrando-se ora conflitos entre diferentes dispositivos sobre mesmo tema, ora lacunas 
(ausência de normas), que podem comprometer a tomada de decisão, notadamente com relação aos RSS, tema que ora interessa.

Nesta seara:

Colisão de princípios e o conflito de regras manifestam-se quando duas normas, utilizadas independentemente, trazem resultados inconciliáveis uma com a outra, ou seja, conduzem à concretização de dois juízos normativos que se contradizem. Esses dois confrontos diferenciam-se no modo de solucionamento. (DERANI, 2007, p. 26).

Com efeito, pode-se ponderar que, nas ciências jurídicas, que quando dois princípios colidem, um precisa dar lugar ao outro, o que não pressupõe, de forma alguma, que o princípio que não prevaleceu seja supostamente inválido ou que aquele que predominou seja o único aplicável a situações correlatas, e muito menos que tal colisão constitua-se numa uma exceção jurídica. Na verdade, o que ocorre é que, num determinado caso concreto, com todas as suas circunstâncias peculiares, há a precedência de um preceito sobre o outro, o que pode ocorrer de maneira inversa em outra situação com circunstâncias próprias. Para Derani (2007) isto ocorre porque os princípios no caso concreto têm diferentes pesos. "O conflito entre as regras jurídicas desenvolve-se na dimensão da validade; já a colisão de princípios, porque somente princípios válidos podem colidir, ocorre além da dimensão da validade, porém na esfera dos pesos” (p. 26).

Por outro lado, Meirelles (2007) esclarece a razão do ordenamento jurídico brasileiro possibilitar esta pluralidade de normas, ao tecer considerações sobre as diferentes espécies de atos administrativos existentes no direito pátrio, agrupando-os em cinco espécies, a saber: "atos administrativos normativos; atos administrativos ordinatórios; atos administrativos negociais; atos administrativos enunciativos; atos administrativos punitivos." (p. 179). O consagrado autor ainda esclarece que, em seu entendimento, nestas categorias cabem todos os atos administrativos propriamente ditos, excluídos os atos legislativos e os judiciais típicos, que formariam dois gêneros à parte.

Não obstante, o próprio Meirelles (2007) ainda explica que os atos administrativos normativos são aqueles que contém um comando geral do Executivo, visando à correta aplicação da lei. O objetivo imediato de tais atos é explicar a norma legal a ser observada pela administração e pelos administrados. Esses atos expressam em minúcia o mandamento abstrato da lei, e o fazem com a mesma normatividade da regra legislativa, embora sejam manifestações tipicamente administrativas. "A essa categoria pertencem os decretos regulamentares e os 
regimentos, bem como as resoluções, deliberações e portarias de conteúdo geral” (MEIRELLES, 2007, p. 179).

Aprofundando este raciocínio, cabe expor que, se os atos administrativos que servem para aplicar ou regulamentar uma lei se subdividem em decretos, regulamentos, regimentos, resoluções administrativas e deliberações, os mesmos, numa subdivisão ainda mais específica e detalhada, podem se classificar como instruções, portarias, circulares, ordens de serviço e outros, salientando-se que, independentemente de qual seja sua classificação ou nomenclatura, nenhum ato administrativo pode, via de regra, contrariar a lei (em sentido estrito), sob pena de ser considerado ilegal.

Quanto à diferenciação entre um ato e outro, o diagrama da figura 3 apresenta uma distinção didática.

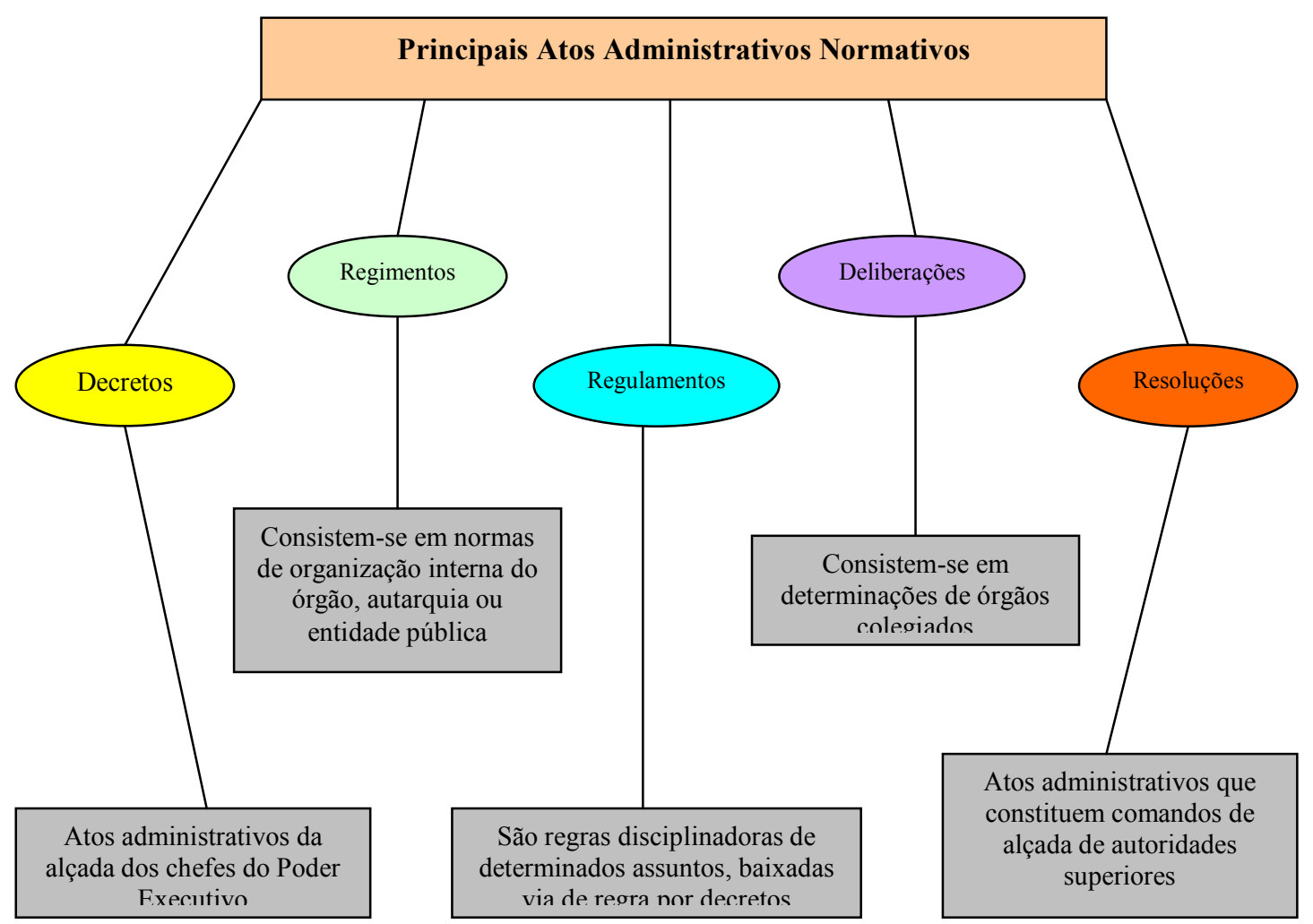

Fonte: elaborado pelo autor.

Figura 3: Principais atos administrativos normativos

Resumindo o que já fora exposto, tem-se também o quadro 2. 


\begin{tabular}{|l|l|}
\hline \multicolumn{1}{|c|}{ LEIS } & \multicolumn{1}{c|}{ ATOS ADMINISTRATIVOS } \\
NORMATIVOS
\end{tabular}

Fonte: elaborado pelo autor.

\section{Quadro 2: Classificações hierárquicas de leis e atos normativos administrativos}

Quanto à hierarquia ${ }^{11}$ das leis (pela ordem de importância), classificam-se as normas da seguinte forma:

$1^{\circ}$ ) Constituição Federal;

$2^{\circ}$ ) Emendas à Constituição;

$3^{\circ}$ ) Leis complementares;

$4^{\circ}$ ) Leis ordinárias;

$\left.5^{\circ}\right)$ Decretos regulamentares;

$6^{\circ}$ ) Outras normas de hierarquia inferior / atos administrativos normativos.

Por sua vez, como exemplo de um ato administrativo com efeito normativo (que contribui para a pluralidade das leis ambientais no país), cita-se a resolução $n^{\circ} 283 / 01$ do CONAMA (2001), a qual acrescentou ao conjunto dos até então considerados resíduos de serviços de saúde - RSS - novas categorias que passariam a pertencem ao mesmo como fontes geradoras, tias como: centros de pesquisa, desenvolvimento ou experimentação na área de farmacologia e saúde, medicamentos e imunoterápicos vencidos ou deteriorados, resíduos provenientes de necrotérios, funerárias e serviços de medicina legal e, também, aqueles provenientes de barreiras sanitárias (CONAMA, 2001).

11 Ressalte-se que não há o que se falar em hierarquia quando se compara leis de origem federal, estadual e municipal, tendo em vista que cada ente federativo, ou seja, cada esfera legislativa tem o seu campo próprio de atuação. 
A ANVISA também edita normas sobre tais resíduos, como, por exemplo, a RDC 33/2003 (posteriormente substituída pela RDC 306, de 07 de dezembro de 2004, norma atualmente em vigor), que classifica os resíduos dos serviços de saúde em grupos distintos, conforme já mencionado anteriormente.

Até mesmo Ministérios Federais não ligados diretamente à área ambiental, já editaram normas a este respeito, inclusive que versavam sobre RSS, como, por exemplo, a Portaria $\mathrm{n}^{\mathrm{o}} 485$, de 11 de novembro de 2005, que aprovou a Norma Regulamentadora - NR no 32 (BRASIL, 2005), a qual dispõe sobre segurança e saúde no trabalho realizado em serviços de saúde.

Nos Estados-membros, também é comum a existência de órgãos, entidades, autarquias e secretarias que editam normas (atos normativos) de caráter ambiental. Em São Paulo, por exemplo, merece destaque o Conselho Estadual do Meio Ambiente (CONSEMA), órgão ligado à Secretaria Estadual do Meio Ambiente (assim como a antiga CETESB), o qual é responsável, dentre outras atribuições, pela aprovação do EIA/RIMA ${ }^{12}$ em todo o Estado (consignando-se que EIA é a sigla para estudo de impacto ambiental, enquanto que RIMA é a sigla de relatório de impacto ambiental).

Nesta ótica, remetendo-se novamente aos ditames da Política Nacional do Meio Ambiente (instituída pela lei $n^{\circ}$ 6.938/81), tem-se que um dos instrumentos mais efetivos de fiscalização desta política é o licenciamento ambiental, instrumento este que evoluiu paralelamente e de forma complementar (não só no Estado de São Paulo, mas em todo o Brasil), à criação e instituição dos relatórios de impacto ambiental (RIMA's).

Sobre o licenciamento ambiental, Farias (2007) considera que

[...] é a base estrutural da gestão ambiental pelas empresas e demais atividades capazes de causar impacto ambiental, visto que cada licença ambiental aponta expressamente uma série de condicionantes que devem ser seguidas pelos empreendedores. Os direcionamentos apontados na licença ambiental devem ser entendidos como os procedimentos básicos da gestão ambiental, nada impedindo que a empresa ou atividade econômica em questão tome cuidados ainda maiores em relação ao meio ambiente do que aqueles prescritos pela Administração Pública. (p. 32).

\footnotetext{
12 "Dependerá de elaboração de estudo de impacto ambiental e respectivo relatório de impacto ambiental - RIMA, a serem submetidos à aprovação do órgão estadual competente, e do IBAMA em caráter supletivo, o licenciamento de atividades modificadoras do meio ambiente, tais como: Estradas de rodagem com duas ou mais faixas de rolamento; Ferrovias; Portos e terminais de minérios, petróleo e produtos químicos (...) Obras hidráulicas para exploração de recursos hídricos (...) Extração de combustível fóssil (petróleo, xisto, carvão) (...); Aterros sanitários (...) Complexo e unidades industriais e agro-industriais (petroquímicos, siderúrgicos, cloroquímicos, destilarias de álcool, hulha, extração e cultivo de recursos hídricos) (...) Qualquer atividade que utilize carvão vegetal, em quantidade superior a dez toneladas por dia”. (NOGUEIRA, 2008, p. 91-92).
} 
Uma vez desrespeitados ou extrapolados os termos do licenciamento concedido pelo poder público, deverá a organização responder judicialmente pelos prejuízos ambientais ocasionados, na esfera civil e penal ${ }^{13}$, se for o caso.

Feitas estas considerações, frise-se que, retomando-se a discussão anterior, até mesmo os municípios podem dispor ou legislar sobre temas de interesse ambiental.

Especificamente quanto ao tema do estudo ora realizado, destaca-se a lei complementar municipal (do Município de Ribeirão Preto) de $n^{\circ}$ 1.790, datada de 27 de dezembro de 2004 (RIBEIRÃO PRETO, 2004), que alterou a lei complementar municipal $n^{\circ} 847$, datada de 29 de março de 1999 (RIBEIRAO PRETO, 1999), instituindo a taxa de coleta, transporte, tratamento e destinação final de resíduos de serviços de saúde e congêneres. $O$ fato gerador para a cobrança da mencionada taxa, de acordo com a referida Lei Municipal, encontra-se previsto em seu artigo $1^{\circ}$, in verbis:

\begin{abstract}
Artigo $1^{\circ}$ - Constitui fato gerador da Taxa de Coleta, Transporte, Tratamento e Destinação Final de Resíduos de Serviços de Saúde e Congêneres, a utilização efetiva ou potencial, dos serviços de coleta, transporte, tratamento e destinação final de resíduos de serviços de saúde e congêneres, prestados ao contribuinte ou colocados a sua disposição, nos limites e nas condições estabelecidas pela legislação municipal especifica.
\end{abstract}

Por todo o exposto, pode-se concluir que, em que pese a descentralização normativa (e o excesso de normas), o sistema de tratamento de RSS se define como um conjunto de unidades, técnicas, processos e procedimentos que alteram as características físicas, físico-químicas, químicas ou biológicas dos resíduos e conduzem à minimização do risco à saúde pública e à qualidade do meio ambiente (CONAMA, 2001; ANVISA, 2003 e 2004). No mesmo sentido, uma das obras organizadas por Philippi Jr. (2005, reimp. 2008).

De todo modo, esse excesso de normas (sejam leis propriamente ditas ou atos administrativos com força de lei), sobre matérias ambientais tão importantes, como resíduos sólidos ou, mais especificamente, resíduos de serviços de saúde - RSS - e seu gerenciamento (produção, tratamento, transporte, descarte e disposição final) pelas entidades geradoras (o que envolve diretamente a saúde pública urbana e, em caso de má gestão ou de decisão equivocada,

\footnotetext{
${ }^{13}$ O Ministério Público pode intervir em casos de danos ao meio ambiente, impondo ao infrator a assinatura de um Termo de Ajustamento de Conduta (TAC), como forma, inclusive, de prevenir eventual ação judicial de responsabilidade. O TAC seria assim uma última chance dada ainda na esfera administrativa, para a organização que extrapolou de seus limites e ocasionou danos ambientais para a coletividade. Nesse sentido Akaoui (2008, p. 69), para quem "o posicionamento do Egrégio Conselho Superior de Ministério Público do Estado de São Paulo (...) no sentido de que, tendo havido compromisso de ajustamento que atenda integralmente a defesa dos interesses difusos objetivados no inquérito civil, é caso de homologação do arquivamento do inquérito."
} 
com risco de comprometimento da vida de centenas ou mesmo de milhares de pessoas), muitas vezes acaba mais por atrapalhar (notadamente quando se vislumbra algum tipo de conflito legislativo), do que auxiliar as pessoas diretamente envolvidas com o problema.

Para Oliveira (1997, p. 89)

Somadas a outras dezenas de leis de ordem estadual e municipal, além de decretos, resoluções e portarias, tem-se a existência de uma vasta e dispersa legislação ambiental, difusamente tratando do interesse ambiental, demonstrando ineficiência no combate efetivo da degradação aos recursos naturais.

Vislumbra-se assim a importância de trabalhos que tomem como objeto de estudo questões ambientais, e que possam, no futuro, contribuir como iniciativas de mudança para o direito ambiental nacional, propugnando pela unificação legislativa.

Afinal, a preocupação com os problemas ambientais não se limita só às ciências humanas aplicadas como a administração, a economia e o direito, ou a meros problemas de gestão e operacionais de situações cotidianas, mas ocupa um campo notadamente maior, se interseccionando e inter-relacionando também e principalmente, de forma paulatina e crescente, com a questão dos direitos humanos (também muito em voga neste início de Século XXI), mais propriamente com a sua chamada $3^{\mathrm{a}}$ (terceira) geração (conceito internacionalmente aceito), uma vez que a vida num meio ambiente sadio e ecologicamente equilibrado é considerada também um direito humano fundamental, da mesma forma que o é o direito à vida, à liberdade, e à igualdade. Neste sentido, saliente-se os ensinamentos de Comparato (2003).

Portanto, pode-se dizer sem sombra de medo que a vida num meio ambiente sadio e ecologicamente equilibrado se constitui num direito humano primordial da chamada $3^{\text {a }}$ (terceira) geração de direitos humanos, encontrando-se vinculado à proteção do todo coletivo desprotegido. Nessa linha de raciocínio, frise-se Moraes (2001).

Por derradeiro, Sung e Silva (2007), tece uma série de considerações sobre ética e meio ambiente. Para ele, a ética ecológica exige também uma mudança de atitude individual, posto que os homens não devem se considerar donos da natureza, mas sim parte dela e, portanto, coresponsáveis pela manutenção do equilíbrio ecológico. Assim, não só a geração atual tem direito à uma vida digna, mas também as gerações que ainda virão partilham desse mesmo direito. Assim, "destruir o planeta implica em retirar o direito de viver das futuras gerações." (SUNG; SILVA, 2007, p. 52). 


\section{CASOS DO ESTUDO}

O estudo multicaso ora realizado abrangeu, como já exposto, quatro organizações que operam na área da saúde no município de Ribeirão Preto, geradoras, portanto, de resíduos inerentes a estes serviços - os RSS.

Todas as organizações pesquisadas possuem natureza distinta umas das outras, inclusive as duas de origem pública, eis que enquanto uma delas se constitui num posto de saúde municipal no sentido estrito da palavra, a outra atua num esquema de parceria, que envolve, além do poder público municipal, o poder público estadual (ainda que de maneira indireta), através de suas autarquias, como o Hospital das Clínicas de Ribeirão Preto e a USP (por meio da Faculdade de Medicina de Ribeirão Preto), além de fundação pública, como a FAEPA.

Não bastasse, a própria instituição puramente municipal estudada possui o seu grau de complexidade, eis que se trata da única Unidade Básica Distrital de Saúde (representada pela sigla UBDS) da região central do município (funcionando assim 24 horas por dia, todos os dias), além de ser, também, o posto de saúde que congrega o maior número de pacientes, o maior número de atendimentos médicos e odontológicos, o maior número de procedimentos clínicos e a maior área de abrangência geográfica de toda a rede de saúde municipal (a qual abrange 35 unidades, a maioria composta de unidades básicas, que funcionam apenas em dias da semana e em horários parecidos com os horários comerciais).

Com efeito, a relação das unidades municipais de saúde, conforme informações fornecidas pela própria Secretaria Municipal da Saúde de Ribeirão Preto, se divide administrativamente em 5 (cinco) distritos (Central, Oeste, Norte, Leste e Sul), distribuindo-se geograficamente como mostrado nos quadros 3 e 4 .

\begin{tabular}{|c|}
\hline Distrito Central \\
\hline UBDS Central \\
\hline UBS Vila Tibério \\
\hline UBS Campos Elíseos \\
\hline UBS João Rossi \\
\hline CSE Vila Tibério \\
\hline
\end{tabular}


PAM II Setor Pediatria

Quadro 3: Unidades básicas e distrital da região central

\begin{tabular}{|l|l|l|l|}
\hline Distrito Oeste & Distrito Norte & Distrito Leste & Distrito Sul \\
\hline UBDS Sumarezinho & $\begin{array}{l}\text { UBDS Quintino } \\
\text { Facci II }\end{array}$ & $\begin{array}{l}\text { UBDS Castelo } \\
\text { Branco }\end{array}$ & UBDS Vila Virgínia \\
\hline UBS Dom Mielle & UBS Marincek & UBS Jardim Juliana & $\begin{array}{l}\text { UBS Adão do Carmo } \\
\text { Leonel }\end{array}$ \\
\hline UBS Ipiranga & $\begin{array}{l}\text { UBS Quintino } \\
\text { Facci I }\end{array}$ & UBS Vila Abranches & $\begin{array}{l}\text { UBS Jardim Maria } \\
\text { das Graças }\end{array}$ \\
\hline UBS José Sampaio & $\begin{array}{l}\text { UBS Jardim } \\
\text { Aeroporto }\end{array}$ & UBS Jardim Zara & $\begin{array}{l}\text { UBS Parque Ribeirão } \\
\text { Preto }\end{array}$ \\
\hline UBS Presidente Dutra & $\begin{array}{l}\text { UBS Valentina } \\
\text { Figueiredo }\end{array}$ & UBS Bonfim Paulista & \\
\hline $\begin{array}{l}\text { UBS Maria Casagrande } \\
\text { Lopes }\end{array}$ & $\begin{array}{l}\text { USF Ribeirão } \\
\text { Verde }\end{array}$ & UBS São José & \\
\hline UBS Vila Recreio & UBS Simioni & UBS Santa Cruz & \\
\hline UBS Vila Albertina & UBS Vila Mariana & & \\
\hline CSE Ipiranga & & & \\
\hline CMSC Vila Lobato & & & \\
\hline
\end{tabular}

\section{Quadro 4: Unidades básicas, distritais e outras que compõem a rede municipal}

Por outro lado, mesmo entre as organizações pesquisadas que não possuem natureza pública, existem diferenças consideráveis. Enquanto uma delas se constitui numa organização puramente privada, atendendo somente pacientes particulares ou que possuam convênio médico, a outra, além de atuar em parceria com o estado (atendendo assim, além de seus próprios clientes, pacientes encaminhados pelo SUS, cujos serviços lhe são remunerados pelo governo), ainda foi constituída na forma de entidade filantrópica (ou seja, que não almeja lucro), distinguindo-se, 
desta forma, da primeira, em matéria de objetivos, metas, diretrizes, público-alvo e questões operacionais.

Feitas estas considerações preliminares, serão apresentadas a seguir as organizações de saúde que foram pesquisadas para realização do presente estudo (ressaltando-se desde já que houve autorização expressa de cada uma delas, por meio de seus representantes ou gerentes conforme anexos que seguem ao final da exposição - para que se pudesse identificá-las neste trabalho).

\subsection{Unidade Básica Municipal de Saúde - UBDS “Dr João Baptista Quartin” - Central (Instituição Pública)}

Situada na área central da cidade, na avenida Jerônimo Gonçalves $\mathrm{n}^{\circ}$ 466, a mais antiga unidade pública municipal de saúde14 foi também a primeira a ganhar o status de UBDS, o que significa que, além de se consistir na principal unidade ou pólo do chamado Distrito Central (conforme divisão administrativa e geográfica realizada pela Secretaria Municipal da Saúde), ela ainda congrega o atendimento de toda uma região com vasta densidade populacional e alto índice de urbanização, composta pelo Centro, Vila Giroldo, Vila Pedro II e parte dos bairros Campos Elíseos, Vila Tibério e Jardim Álvaro Costa Couto (figura 4) .

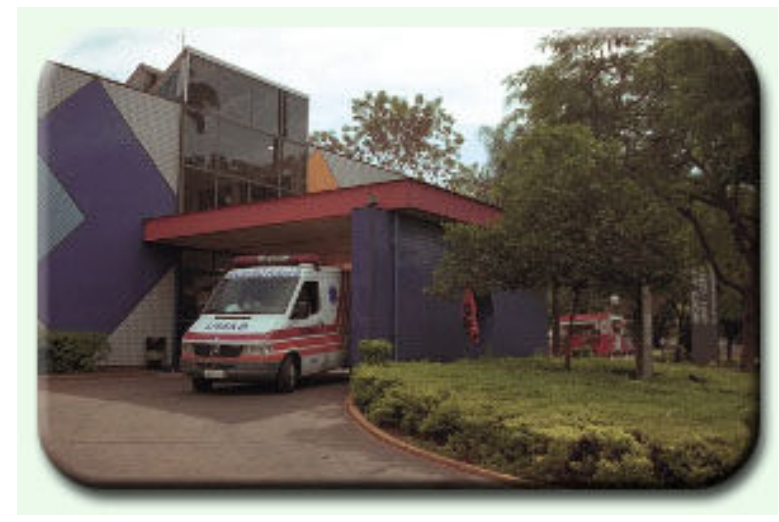

Fonte: Prefeitura Municipal de Ribeirão Preto (2008)

Figura 4: Unidade Básica de Saúde do Distrito Central

\footnotetext{
14 “A Unidade Básica de Saúde desde sempre foi pensada como a porta de entrada de um sistema público de serviços de saúde. Como porta ela absorveria a demanda universal, daria resolutividade a quase $80 \%$ das intercorrências, encaminharia para serviços especializados e internações os casos de maior complexidade, acompanharia programaticamente grupos etários ou de crônicos, processaria uma vigilância em saúde em sua área de abrangência e ainda realizaria a relação política com o seu entorno". (BOTAZZO, 1999, p. 17).
} 
Não bastasse, ela atende também pacientes vindos de praticamente toda a rede pública municipal, inclusive das áreas mais distantes e periféricas da cidade.

Isso se explica não só pelo fato de funcionar diariamente, vinte e quatro horas por dia (inclusive sábados, domingos e feriados), mas também por oferecer, além dos serviços básicos oferecidos por praticamente todas as unidades de saúde municipais, grande número de especialidades médicas, além do próprio atendimento de emergência, para crianças e adultos, inclusive em odontologia.

Fazendo-se um pequeno aparte, é imperioso ressaltar que, quando se fala em atendimento de emergência, notadamente em sábados, domingos, feriados ou mesmo em dias úteis, só que em horários noturnos, deve-se registrar que a maior parte das unidades que compõem a rede municipal, enumeradas em tópico anterior, constituem-se apenas em unidades básicas de saúde (representadas pela sigla UBS), razão pela qual, além de limitarem seu atendimento à população local, normalmente das imediações do próprio bairro em que se situam, possuem horário de funcionamento fixo, parecido com o horário comercial (como, por exemplo, das $09 \mathrm{~h} 00$ às $17 \mathrm{~h} 00$ ), e realizam suas atividades, normalmente, apenas de segunda a sexta-feira, não funcionando, portanto, nem à noite e nem aos finais de semana.

Não bastasse, a maior parte das UBS não possui um grande número de especialidades clínicas disponíveis para a população, sendo certo que a maioria sequer dispõe de atendimento odontológico (o qual, praticamente, só existe nas unidades básicas distritais de saúde do município).

Feitas estas considerações, apresenta-se no quadro 5 os principais tipos de atendimento prestado e de especialidades médicas oferecidas pela unidade.

\begin{tabular}{|l|l|l|}
\hline \multicolumn{1}{|c|}{ Atendimento Emergencial } & \multicolumn{1}{|c|}{ Atendimento Básico } & \multicolumn{1}{c|}{ Especialidades de Saúde } \\
\hline Adultos e crianças & Clínica médica & Saúde ocupacional \\
\hline Soro anti-rábico & Ginecologia e obstetrícia & Serviço social \\
\hline Odontologia & Assistência domiciliar & Otorrinolaringologia \\
\hline & Enfermagem & Eletroencefalograma \\
\hline & Vacinação & Eletrocardiograma \\
\hline & Odontologia & Cardiologia \\
\hline & & Dermatologia \\
\hline
\end{tabular}




\begin{tabular}{|l|l|l|}
\hline & & Endocrinologia \\
\hline & & Neurologia \\
\hline & & Oftalmologia \\
\hline & & Radiologia \\
\hline & & Traumatologia \\
\hline & & Ultrassonografia \\
\hline
\end{tabular}

\section{Quadro 5: especialidades médicas da UBDS Central}

Por todos estes fatores, aliados à sua estratégica localização, a demanda por atendimentos médicos e odontológicos em geral na UBDS “Dr. João Baptista Quartin” - que é, inclusive, muito mais conhecida como UBDS "Central" (inclusive pelo próprio pessoal da Secretaria Municipal da Saúde) - é tão intensa, que a transforma na maior unidade prestadora de serviços de saúde municipal (dona do maior número de pacientes cadastrados e de procedimentos clínicos da rede), o que a torna, sem sombra de dúvidas, uma organização extremamente representativa, seja para pesquisas quantitativas, seja para qualquer estudo de caso em uma dissertação de mestrado.

\subsection{Hospital São Francisco (Organização Privada)}

Fundado no ano de 1945 por uma equipe de médicos liderada pelo Dr. Waldemar Bamsley Pessoa, o Hospital São Francisco - cuja razão social é Hospital São Francisco Sociedade Empresarial Ltda. (inscrito no C.N.P.J./MF sob o $\mathrm{n}^{\mathrm{o}} 55.980 .882 / 0001-90$, conforme dados fornecidos pela JUCESP - Junta Comercial do Estado de São Paulo) - funciona até hoje no mesmo endereço, qual seja, na rua Bernardino de Campos $n^{\circ}$ 912, no chamado quadrilátero central da cidade de Ribeirão Preto (figura 5). 


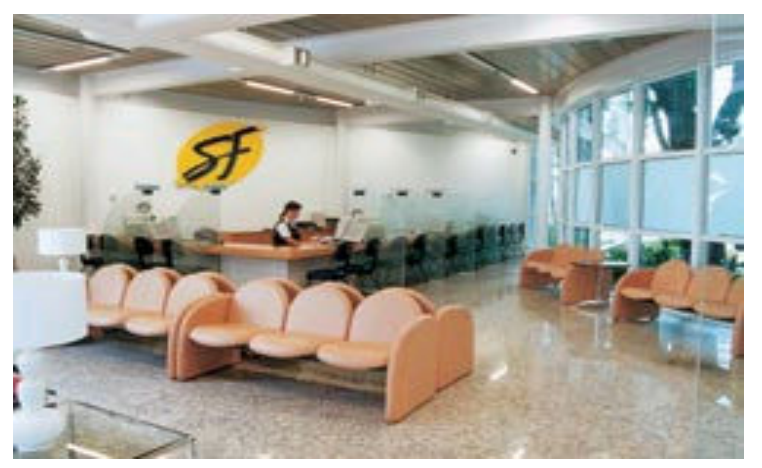

Fonte: Hospital São Francisco (2008)

\section{Figura 5: Interior do Hospital São Francisco}

Constituído como uma sociedade por cotas de responsabilidade limitada, integraliza seu capital social (de acordo com a JUCESP) a quantia de R \$ 3.301.782,87 (três milhões, trezentos e um mil, setecentos e oitenta e dois reais e oitenta e sete centavos), o que o torna uma das maiores empresas privadas de atendimento hospitalar do município.

Em seus mais de 60 (sessenta) anos de história, o Hospital São Francisco ganhou destaque no interior do Estado de São Paulo como o primeiro do interior a possuir tratamento avançado contra o câncer, e isso ainda na década de 1960 do século passado. Já na década de 1980, dentro de suas instalações, foi inaugurado o Hospital do Coração e, na seqüência, o Centro de Diálise e Transplante Renal. Atualmente, o hospital conta com cento e quarenta e nove leitos e possui, inclusive, um pólo direcionado ao estudo da ciência e pesquisa médica, a Fundação Waldemar Bamesley Pessoa.

$\mathrm{Na}$ sua sede, o principal objetivo é o fornecimento das mais variadas atividades de atendimento hospitalar, para pacientes particulares ou que possuam convênios médicos privados aceitos pelo hospital. Dentre os produtos e serviços oferecidos pelo Hospital São Francisco, destacam-se: a angiologia digital, um centro de terapia intensiva, procedimentos de ecocardiografia, endoscopia digestiva, fisioterapia, hemodinâmica, radiologia geral e ressonância magnética, laboratórios de análises médicas (em prédio próprio distinto da sede), tomografia computadorizada espiral, serviços de ultra-sonografia e vários outros. Por outro lado, o hospital também dispõe de unidades próprias, em endereços diversos, para atendimento de urgências médicas e emergências infantis.

Como é óbvio, o próprio porte da empresa, somado com toda a diversidade de especialidades e quantidade de serviços e procedimentos médicos que oferece, torna a mesma, em 
última análise, uma das grandes geradoras de RSS no município, fato que é compreendido pela sua própria diretoria executiva, uma vez que a mesma instituiu sua própria Comissão de Gerenciamento de Resíduos, dentro da administração do hospital.

O fator acima, somado à tradição da mencionada organização dentro do município, fez com que fosse escolhida como um dos quatro casos objetos do estudo realizado.

\subsection{Hospital Sociedade Portuguesa de Beneficência (Fundação - Parceria Público-Privada)}

Conhecido popularmente como "Beneficência Portuguesa" e considerado como mais um hospital particular da cidade (por atender não só pessoas encaminhadas pelo SUS, mas também conveniados de planos privados de saúde), o Hospital Sociedade Portuguesa de Beneficência (figura 6), na verdade, foi constituído como uma entidade filantrópica e, por este motivo, não possui cadastro nos registros da JUCESP, como ocorre geralmente com outras empresas privadas, mas apenas contrato social lavrado em Cartório Extrajudicial (C.N.P.J./MF nº 55.990.451/0001$05)$.

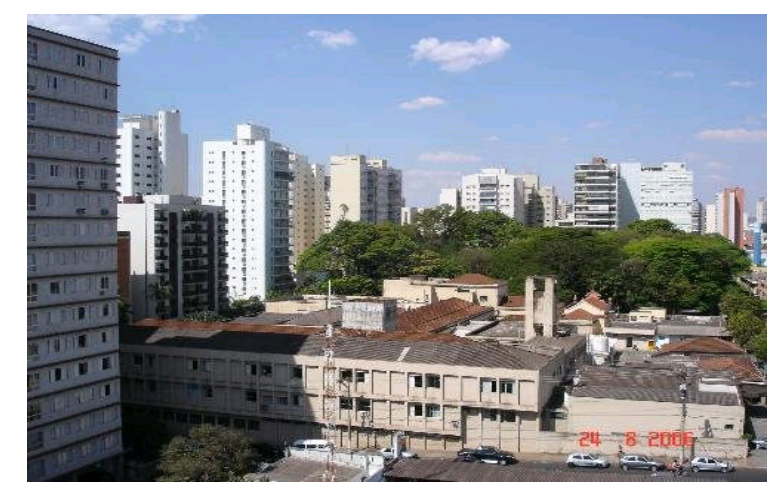

Fonte: www.jornalacidade.com.br

\section{Figura 6: Vista aérea do hospital Sociedade Beneficência Portuguesa, a partir da rua Álvares Cabral}

O hospital - o segundo do município - foi inaugurado em $1^{\circ}$ de janeiro de 1919 , no mesmo prédio onde hoje se situa (rua Tibiriçá $\mathrm{n}^{\circ}$ 1172, centro, Ribeirão Preto), mas sua mantenedora foi constituída doze anos antes, em 28 de setembro de 1907, quando um grupo de doze portugueses, que residiam na cidade, se reuniu fundando oficialmente a entidade com o 
nome de Sociedade de Beneficência Portuguesa Dom Carlos I (uma homenagem ao então o rei de Portugal). Em 1910 (dois anos após sua fundação), a república foi proclamada em Portugal e, com o rei Dom Carlos I já falecido, optaram seus fundadores em trocar o patrono da entidade, adotando o nome Sociedade Portuguesa de Beneficência como a mantenedora do "Hospital da Imaculada Conceição", sua designação oficial.

$\mathrm{Na}$ época da construção do seu prédio, houve uma intensa campanha dos portugueses da cidade, inclusive angariando fundos com portugueses residentes em outros municípios do estado, o que culminou em um total de trezentos e quarenta sócios.

Atualmente, o hospital conta com cento e cinqüenta leitos (sendo que, geralmente, a totalidade dos mesmos permanece ocupada), além de mais dez leitos de UTI, possuindo ainda farmácia própria e arco cirúrgico especializado em radiografias intervencionistas. No ano de 2006, registrou uma média mensal de oitocentos e trinta e cinco atendimentos, contra oitocentos e quinze no ano de 2005 e setecentos e sessenta e um atendimentos em 2004.

A Beneficência Portuguesa também conta com um centro especializado de oncologia - o CEON - o qual, juntamente com o Hospital das Clínicas de Ribeirão Preto, integra o Programa de Qualidade em Radiologia - PQRT - do Instituto Nacional do Câncer do Governo Federal, se constituindo assim num centro de excelência em radiologia e quimioterapia.

Curiosamente, o hospital não possui site institucional e nem página própria na Internet.

No mais, a referida instituição foi escolhida como uma das quatro analisadas na pesquisa por ser uma das únicas (juntamente com a Santa Casa) que trabalha com o regime de parceria público-privada no município de Ribeirão Preto, ou seja, além de ser um hospital que pertence ao chamado terceiro setor ou, simplesmente, filantrópico ${ }^{15}$ (permanecendo assim na dependência do recebimento de verbas oficiais), atende e recebe pacientes que lhe são encaminhados pelo SUS Sistema Único de Saúde (esta parceria é, aliás, um motivo constante de reclamação da direção do hospital, a qual publicamente se queixa de dificuldades financeiras oriundas da defasagem da tabela do Sistema Único de Saúde, posto que, apesar dos segurados do SUS se consistirem em $85 \%$ das pessoas atendidas na organização - sendo o restante constituído de pacientes que

\footnotetext{
15 "Nos Estados Unidos da América a associação voluntária de indivíduos precedeu a organização do próprio aparato estatal e da atividade empresarial (Moulton e Anheier, 2000:105). Ao longo de sua história, organizações nãolucrativas (registradas ou não perante órgãos públicos) assumiram o desempenho de uma série de papéis voltados para a satisfação de necessidades públicas tidas como não abrangidas pelo escopo de atuação do Estado e das empresas. De acordo com Salamon, organizações não-lucrativas respondem, hoje, por metade dos hospitais, escolas e universidades do país e por cerca de $60 \%$ das agências de serviços sociais, além da maior parte das organizações cívicas e organizações não-governamentais". (SUNDFELD, 2005, p. 59).
} 
possuem planos privados de saúde - as receitas totais provenientes destes atendimentos correspondem à apenas $50 \%$ do que o hospital arrecada, vindo o restante dos atendimentos de planos de saúde particular).

Além disso, referido hospital foi pioneiro (atuando conjuntamente com pesquisadores da Unicamp), na elaboração e implantação de um programa de gestão de resíduos químicos (um dos subgrupos no qual se dividem os RSS) em Ribeirão Preto, isso logo após a edição da RDC 306/04 pela ANVISA e antes mesmo da adoção de um plano oficial de gerenciamento de resíduos pela Secretaria da Saúde Municipal.

Isso pode ser explicado, ao menos em parte, por ser a Beneficência Portuguesa também um grande gerador de resíduos hospitalares, notadamente da classe de resíduos químicos e radioativos, o que é até uma conseqüência, pelo fato da mesma possuir um avançado centro de tratamento de câncer.

Não bastasse, sua escolha também se justificou pelo fato de todo o pessoal responsável pela gerência de resíduos da organização ter se mostrado extremamente solícito em fornecer os dados necessários para análise, além de demonstrar, também, interesse no próprio tema da pesquisa e nos resultados do trabalho, o que foi percebido logo nos primeiros contatos prévios realizados.

\subsection{Centro de Saúde Escola do Sumarezinho - UBDS “Joel Domingos Machado" (Parceria Pública Estado -Autarquias - Município)}

O Centro de Saúde Escola "Joel Domingos Machado" (figura 7), popularmente conhecido como Unidade Básica Distrital de Saúde do Sumarezinho (notadamente pelos moradores dos bairros do entorno, que usam com freqüência os serviços de agendamento de especialidades médicas e de pronto atendimento da unidade), bem como por Centro de Saúde Escola da Faculdade de Medicina de Ribeirão Preto (FMRP) da USP (denominação mais utilizada pelos profissionais da USP, da Fundação de Ensino e Pesquisa - FAEPA ou do Hospital das Clínicas, que ajudam a compor o quadro de funcionários e colaboradores da entidade), consiste-se num tipo especial de parceria de prestação de serviços na área de saúde, que não envolve nenhuma organização privada propriamente dita, mas sim diferentes esferas e instâncias do próprio poder público, se consistindo assim num caso sui generis muito interessante de ser analisado. 


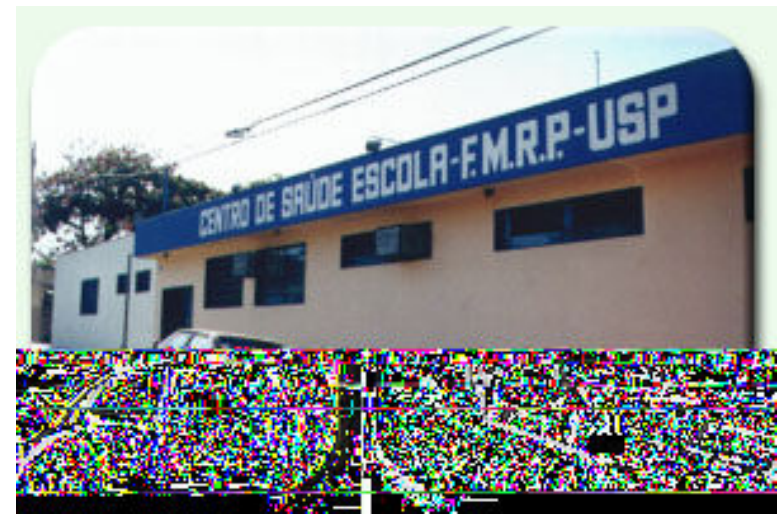

Fonte: Prefeitura Municipal de Ribeirão Preto (2008)

Figura 7: Centro de Saúde Escola "Joel Domingos Machado"

Referida organização se situa na rua Cuiabá $n^{0}$ 601, na divisa dos bairros Sumarezinho e Monte Alegre, em Ribeirão Preto, funcionando vinte e quatro horas por dia e se consistindo na unidade distrital que congrega a grande área geográfica e populacional conhecida como zona oeste da cidade, abrangendo os seguintes bairros: Sumarezinho, Alto do Ipiranga, Vila Amélia, Cidade Universitária, Monte Alegre, Campus Universitário da USP, Jardim Emir Garcia, Jardim Mário Paiva Arantes, Jardim Paiva, Jardim Arlindo Laguna e Jardim Dr. Paulo Gomes Romeo.

A sua constituição e o trabalho que presta à comunidade surgiram de um convênio entre a Prefeitura Municipal de Ribeirão Preto, através da Secretaria Municipal da Saúde, e o Poder Público Estadual, através da própria Universidade de São Paulo, por meio de sua Faculdade de Medicina, bem como do Hospital das Clínicas e da FAEPA.

De acordo com informações colhidas na própria unidade, do seu quadro total de funcionários, hoje, cerca da metade está vinculado à Prefeitura Municipal, possuindo a USP algo em torno de $30 \%$ e o restante possuindo vínculos com a FAEPA. Existem também funcionários terceirizados, notadamente na área da limpeza da unidade de pronto atendimento.

Esses funcionários não se encontram homogeneamente distribuídos, posto que a UBDS conta com duas grandes estruturas prediais distintas, numa delas se concentrando grande parte dos funcionários da USP, Hospital das Clínicas e FAEPA (onde só se trabalha com atendimentos médicos e odontológicos previamente agendados) e, na outra, a maior parte dos funcionários ligados à Secretaria Municipal da Saúde (onde são atendidas as urgências médicas e realizadas consultas e procedimentos emergenciais de saúde). 
Com relação às especialidades médicas e variedade de serviços oferecidos que são colocados à disposição da população na referida unidade, pela Secretaria da Saúde Municipal, destacam-se os relacionados no quadro 6.

\begin{tabular}{|l|l|l|}
\hline Atendimento Emergencial & Atendimento Básico & Especialidades de Saúde \\
\hline Adultos e crianças & Clínica médica & Cardiologia \\
\hline Soro anti-rábico & Pediatria & Saúde Ocupacional \\
\hline & Ginecologia e obstetrícia & Dermatologia \\
\hline & Enfermagem & Eletrocardiograma \\
\hline & Odontologia & Fonoaudiologia \\
\hline & Teste do pezinho & Infectologia \\
\hline & Vacinação & Oftalmologia \\
\hline & & Programa de Hanseníase \\
\hline & & Psicologia \\
\hline & & Radiologia \\
\hline & & Serviço social \\
\hline
\end{tabular}

\section{Quadro 6: especialidades médicas do Centro de Saúde Escola}

Além disso, a unidade possui também quatro Núcleos de Saúde da Família, estabelecidos dentro de sua área de atuação geográfica, os quais realizam o atendimento básico de clínica médica, pediatria e ginecologia das famílias cadastradas em seus bancos de dados, além de desenvolverem também trabalhos em grupo com a comunidade.

Possui ainda comitês de ética (vinculados à Faculdade de Medicina da USP) que analisam e direcionam pedidos de pesquisa provenientes de alunos vinculados a cursos superiores de graduação ou pós-graduação, bem como programas de estágio e residência médica para recém-formados.

Sua estrutura física conta com salas de internação, esterilização, de roupa suja, aposentos de descanso para médicos, refeitório, etc., ou seja, nada fica a dever para grandes organizações hospitalares de âmbito privado.

Por fim, tendo em vista o seu modo peculiar de prestar serviços e operacionalizar todos os seus recursos, com destaque para a parceria entre Prefeitura Municipal, USP, Hospital das 
Clínicas de Ribeirão Preto e FAEPA, mesclando aí poderes públicos e entidades autárquicas diversas, numa modalidade de parceria ainda pouco difundida, esclarecido está sua escolha para também figurar como um dos pólos de estudo da pesquisa. 


\section{PROCEDIMENTOS METODOLÓGICOS}

A seguir são apresentados os principais tópicos relacionados aos procedimentos metodológicos, com a discussão de alguns conceitos, a definição do tipo de pesquisa, o protocolo para o estudo de caso, as formas de coleta e análise dos dados, as etapas da pesquisa e suas limitações.

\subsection{A Pesquisa Científica}

Ruiz (1992, p. 48) ensina que a "pesquisa científica é a realização concreta de uma investigação planejada, desenvolvida e redigida de acordo com as normas da metodologia consagradas pela ciência”. Segundo o aludido autor, o aspecto científico de uma pesquisa é caracterizado justamente pelo método de abordagem do problema que está sendo estudado.

Parra Filho e Santos (2001) destacam a importância do planejamento e dos cuidados com os preceitos teóricos que devem cercar sempre uma investigação científica.

Nesta linha de raciocínio:

Todo o processo exige uma comprovação dos dados apresentados e detalhamento do raciocínio do pesquisador para evidenciar sua proposta e deixar claro, desde o projeto, quais são os objetivos, a determinação do problema da pesquisa, a hipótese e a elaboração do relatório final. (PARRA FILHO; SANTOS, 2001, p. 57).

O mencionado autor considera ainda que, um projeto de pesquisa, para ser bem estruturado, deve conter, sequencialmente, as seguintes etapas: tema, justificativa do tema, objetivo geral, objetivo específico, formulação do problema da pesquisa, formulação da hipótese da pesquisa, metodologia da pesquisa, definição dos termos da pesquisa, bibliografia, cronograma e custos.

É claro que, dependendo do objeto do estudo ou do tipo de pesquisa a ser realizada, existem adaptações que poderão ser feitas nos tópicos retro mencionados, por exemplo, colocando-se a justificativa junto com a introdução, ambos os objetivos - geral e específico num mesmo capítulo, etc.

Não obstante, com relação ao tipo de pesquisa científica, saliente-se desde já que a mesma pode ser classificada de diversas maneiras, dependendo da ênfase que se dá a fatores como a natureza das fontes, tipo de método empregado (indutivo ou dedutivo), e outros. 
[...] a ciência se constitui aplicando técnicas, seguindo um método e apoiando-se em fundamentos epistemológicos. Tem assim elementos gerais que são comuns a todos os processos de conhecimento que pretenda realizar, marcando toda atividade de pesquisa. Mas, além da possível divisão entre Ciências Naturais e Ciências Humanas, ocorrem diferenças significativas no modo de se praticar a investigação científica, em decorrência da diversidade de perspectivas epistemológicas que se podem adotar e de enfoques diferenciados que se podem assumir no trato com os objetivos pesquisados e eventuais aspectos que se queria destacar. Por esta razão, várias são as modalidades de pesquisa que se podem praticar, o que implica coerência epistemológica, metodológica e técnica, para o seu adequado desenvolvimento. (SEVERINO, 2007, p. 117-118).

Não obstante, como já exposto em tópicos anteriores, é certo que o presente trabalho estudou e analisou organizações que atuam na área da saúde e, nesta condição, geram resíduos. O tipo de pesquisa realizada, envolvendo apenas quatro casos concretos de instituições prestadoras de serviços de saúde no município de Ribeirão Preto (dentre as inúmeras existentes), não pode ser considerado um estudo por amostragem ou abrangente de população representativa do todo (isso independentemente da coleta de dados ter sido ou não realizada por meio de entrevistas, inferências, fotografias, gráficos, análises, etc.), razão pela qual, designa-se a presente por pesquisa qualitativa.

Sobre a pesquisa qualitativa serão tecidas considerações mais aprofundadas no tópico que segue, embora se possa deixar consignado desde já, especificamente sobre as pesquisas na área de saúde, que:

Ao considerarmos as relações entre serviços de saúde e pesquisa, queremos chamar ainda a atenção para duas formas de abordar tais relações. A primeira delas se refere ao fato de que tais serviços podem servir de cenário de pesquisas. Se, por exemplo, pretendemos investigar as diferentes representações da doença ou de determinado tratamento, os serviços podem ser considerados como um espaço onde tais representações se produzem e se reproduzem. Essas representações não surgem do vazio. Elas são construídas historicamente, no campo das interações, sofrendo influência das estruturas cristalizadas, orientando e sendo reorientadas pela ação dos sujeitos em suas práticas cotidianas. Assim, as interações entre profissionais de saúde, usuários e serviços pode ser um 'locus' privilegiado de análise para se compreender o que representa a doença ou o tratamento.

Por outro lado, os serviços podem ser o próprio 'objeto de pesquisa', sendo vistos como instituições a serem investigadas. Dentro desse ponto de vista, o eixo da pesquisa não seria diretamente as maneiras de pensar, sentir e expressar, mas a organização interna dos grupos e as lógicas que sustentam suas práticas. A partir dessa organização é que estudaríamos o pensamento, os afetos e a linguagem (Laplantine, 1997). Seus costumes, seus ritos, suas normas e hierarquias, as interações de seus membros, dentre outros aspectos, constituiriam o foco da pesquisa. (BOSI; MERCADO, 2004, p. 101-102).

Feitas estas considerações teóricas preliminares, necessárias para uma compreensão teórica inicial do que é uma pesquisa científica, seguir-se-ão esclarecimentos sobre a pesquisa realizada, a coleta de dados e os procedimentos metodológicos adotados, propriamente ditos. 


\subsection{Tipo de Pesquisa}

Como se pode intuir do que fora exposto no tópico anterior existem várias maneiras de se classificar as pesquisas científicas, seja na área das ciências sociais aplicadas, como, por exemplo, a administração, seja na área das ciências biológicas ou da saúde, seja em qualquer outra área do conhecimento humano.

Em uma dessas classificações possíveis, Severino (2007) considera que, quanto à natureza das fontes, utilizadas para a abordagem e tratamento do seu objeto, a pesquisa pode ser classificada em quatro tipos distintos, quais sejam: bibliográfica, documental, experimental ou de campo. Considera-se importante ressaltar que, o primeiro caso (bibliográfica) se diferencia do segundo (documental), pelo fato de, neste último, o pesquisador se utilizar basicamente de documentos e não de textos autorais propriamente ditos.

Outros modos utilizados pelo autor retro mencionado para classificar as pesquisas científicas são: pesquisas quantitativas e pesquisas qualitativas (que se diferenciam pelo uso de abordagens metodológicas distintas); pesquisas etnográficas; pesquisas participantes; pesquisaação; estudos de caso; pesquisas de análise de conteúdo; etc. Em outra classificação, voltada basicamente aos objetivos da pesquisa, Severino (2007) ainda as distingue em dois outros tipos: pesquisa exploratória e pesquisa explicativa.

As classificações acima apontadas não são unânimes, encontrando variações quanto ao seu entendimento dentre os principais autores do campo da metodologia científica. Por exemplo, Ruiz (1992, p. 50), que, em contraponto a Severino, classifica os tipos de pesquisa de maneira distinta, entendendo que:

Existem diversas espécies de pesquisa científica. Quando um problema é pouco conhecido, ou seja, quando as hipóteses ainda não foram claramente definidas, estamos diante de uma pesquisa exploratória. Seu objetivo, pois, consiste numa caracterização inicial do problema, de sua classificação e de sua reta definição. Constitui, pois, o primeiro estágio de toda pesquisa científica; não tem por objetivo resolver de imediato um problema, mas tão-somente apanhá-lo, caracterizá-lo. A pesquisa teórica tem por objetivo ampliar generalizações, definir leis mais amplas, estruturar sistemas e modelos teóricos, relacionar e enfeixar hipóteses numa visão mais unitária do universo e gerar novas hipóteses por força de dedução lógica. Além disso, supõe grande capacidade de reflexão e de síntese, a par do espírito de criatividade. A pesquisa aplicada toma certas leis ou teorias mais amplas como ponto de partida, e tem por objetivo investigar, comprovar ou rejeitar hipóteses sugeridas pelos modelos teóricos. 
Já Parra Filho e Santos (2001), classificam as pesquisas científicas de uma maneira ainda mais peculiar, qual seja, separando-as de acordo com o fim a que se destinam, isto é: monografia de conclusão de curso de graduação, dissertação de mestrado, tese de doutorado ou livre-docência, dentre outras.

Realizadas todas estas considerações, mister deixar claro, desde já, que o presente trabalho se consistiu em uma pesquisa qualitativa ou, como refere Severino (2007), voltou-se especificamente à abordagem qualitativa do tema pesquisado. ${ }^{16}$

Não obstante a abordagem qualitativa deste trabalho científico e o fato do mesmo se consistir basicamente em um estudo de casos, pode-se dizer também que, quando da coleta, análise ou discussão dos dados obtidos, mesclou-se em termos de procedimentos metodológicos alguns dos demais tipos de pesquisa retro mencionados, como por exemplo, quando foram utilizados alguns dos princípios que norteiam a pesquisa descritiva, ao se proceder as constatações lançadas no capítulo referente aos resultados e à discussão (o que ocorreu por meio da comparação sobre o gerenciamento dos RSS nas organizações estudadas).

Com efeito, relativamente à modalidade de pesquisa chamada estudo de casos (para muitos autores um subgrupo da pesquisa qualitativa), trata-se a mesma de uma estratégia de pesquisa em ciências sociais e aplicadas, que, na visão de Yin (2001), pode ser utilizada para três propósitos distintos: exploratório, descritivo e explanatório ou causal (sendo mais freqüentes para esta modalidade de pesquisa os dois primeiros tipos). Nesta linha de raciocínio, Yin (2001) esclarece que a modalidade de pesquisa "estudo de caso" é a preferida quando o controle que o investigador tem sobre os eventos pesquisados é muito reduzido, bem como quando o foco temporal está voltado para fenômenos contemporâneos ocorridos dentro do contexto da vida social e, ainda, quando os tipos de questões da pesquisa envolvem perguntas da forma "como" e "por que".

Ainda na visão do autor retro mencionado, a utilização da estratégia de pesquisa intitulada estudo de caso está ligada à necessidade de se entender um fenômeno social complexo, sendo certo que a essência deste tipo de pesquisa é tentar esclarecer o porque de ter ou terem sido

\footnotetext{
${ }^{16}$ Por outro lado, como, na visão de vários autores consagrados no campo da metodologia científica, a própria pesquisa qualitativa também se divide em vários subgrupos, é certo que, por tudo o que restou exposto até aqui, o presente trabalho se consistiu (numa abordagem mais específica) num estudo de casos, modalidade de pesquisa que integra os mencionados subgrupos nos quais a abordagem qualitativa se divide.
} 
tomada(s) determinada(s) decisão(ões), bem como as razões dela(s) ter(em) sido implementada(s) e ainda quais foram os resultados alcançados.

Diante desta necessária exposição sobre o estudo de casos e sua relação com as pesquisas descritivas e qualitativas, cumpre retomar o raciocínio anterior e, neste sentido, tem-se que, uma vez que a pesquisa realizada se consistiu num estudo de caso com procedimentos descritivos, deve-se traçar um paralelo entre ela e os métodos descritivos previstos nas ciências estatísticas.

De acordo com Stevenson (2001, p. 4) "a estatística descritiva requer a utilização de modelos gráficos e numéricos para resumir e apresentar os dados".

Destarte, como se tratou de pesquisa qualitativa, a análise dos dados obtidos pelo pesquisador com as entrevistas e com as visitas de conhecimento programadas nas organizações, não foi estatística, como normalmente ocorre com as pesquisas quantitativas. Na verdade, além dos métodos empregados (ou abordagens, como prefere Severino), os objetivos básicos das pesquisas qualitativa e quantitativa são veementemente diferentes, sendo certo que, no caso das primeiras, visa-se alcançar uma compreensão qualitativa das razões e motivações subjacentes dos dados obtidos, enquanto que, no caso das segundas, visa-se somente quantificar esses dados e, a partir daí, generalizar os resultados da amostra colhida junto a toda a população alvo.

Outra diferença entre as pesquisas qualitativas e quantitativas diz respeito ao tamanho da amostra, pequena no caso das primeiras (apresentando um número de casos não representativos da população total objeto do estudo) e grande no caso das segundas (apresentando um número considerável de casos representativos da população, no que tange à situação analisada ou objeto de estudo).

Por outro lado, com relação aos dados que foram analisados, os mesmos não foram obtidos por meio da simples aplicação de questionários respondidos por grande ou significativo número de funcionários das organizações pesquisadas (instrumento típico das pesquisas quantitativas), mas sim por meio da realização de entrevistas de profundidade, com poucas pessoas dentro de cada instituição, o que é outra característica típica das pesquisas qualitativas.

Com efeito, Severino (2007, p. 121) esclarece que, no tipo de pesquisa "que se concentra no estudo de um caso particular, considerado representativo de um conjunto de casos análogos, por ele significativamente representativo, a coleta de dados e sua análise se dão da mesma forma que nas pesquisas de campo, em geral”. 
Sobre as pesquisas qualitativas na investigação de dados sobre instituições que prestam serviços de saúde, cabe ainda transcrever:

\begin{abstract}
A pesquisa qualitativa constitui um campo no qual é possível visualizar, a cada dia mais intensamente, o interesse pela exploração dos fenômenos sanitários e dos serviços de saúde. Dos múltiplos temas inseridos nesse contexto, a análise dos dados é um dos que despertam a crescente atenção de administradores, acadêmicos e pesquisadores envolvidos na avaliação e realização de estudos qualitativos na área de saúde. Esta preocupação data de período recente, pois essa temática, quando não ignorada, tradicionalmente não recebia tratamento á altura de sua relevância, já que os métodos quantitativos dominavam e constituíam as irrefutáveis estratégias no terreno da análise dos dados. (BOSI; MERCADO, 2004, p. 137).
\end{abstract}

De acordo com artigo contido na obra organizada pela mencionada autora, atualmente, a investigação qualitativa tem envolvido tanto os campos das ciências e disciplinas da área da saúde, quanto o ramo das ciências sociais e humanas aplicadas, havendo cada vez um número maior de trabalhos científicos que se dedicam à análise qualitativa de dados em estudos de caso reais.

Não obstante, uma última diferença a ser apontada entre os métodos de pesquisa qualitativa e quantitativa, diz respeito aos resultados alcançados por cada uma delas, a primeira servindo, via de regra, para desenvolver uma compreensão inicial do problema, ao passo que a última se utiliza do fim obtido para recomendar um determinado curso ou diretriz para o objeto do tema pesquisado.

Além dos princípios que regem as pesquisas qualitativas, dos ditames (em forma de protocolo) que devem guiar os estudos de caso e da utilização de regras da pesquisa descritiva, quando houve a necessidade, no presente trabalho, de se levantar previamente as normas, portarias, decretos, regulamentos e das leis propriamente ditas existentes (ou que ao menos façam menção) sobre os RSS e que influenciam diretamente em sua gestão e gerenciamento, configurou-se também a chamada pesquisa bibliográfica ${ }^{17}$, que, na visão do mestre Severino (2007, p. 122) é "aquela que se realiza a partir do registro disponível, decorrente de pesquisas anteriores, em documentos impressos, como livros, artigos, teses, etc. Utiliza-se de dados ou de categorias teóricas já trabalhados por outros pesquisadores e devidamente registrados".

Denota-se, portanto, que dentre todos os procedimentos metodológicos que foram utilizados no presente trabalho, houve o amálgama de alguns preceitos que regem os tipos de

\footnotetext{
${ }^{17}$ Merece ser destacado também que, além do uso de material bibliográfico (como livros, artigos acadêmicos, legislações, etc.), a pesquisa também se baseou em informações colhidas da Internet, de sites das autarquias, agências e demais instituições envolvidas no tema do trabalho, conforme se pode conferir em suas referências.
} 
pesquisa acima descritos, sendo certo que tudo fora feito com o intuito de se chegar ao resultado esperado e sempre com o alicerce na pesquisa qualitativa e nos princípios que devem nortear qualquer estudo de caso, inclusive com todas as etapas da pesquisa previamente definidas em protocolo, conforme tópico que segue.

\subsubsection{O Protocolo para o Estudo de Caso}

Como já visto, o estudo de caso é a modalidade de pesquisa científica (qualitativa) que serve para a compreensão de fenômenos individuais, organizacionais, sociais e políticos no tocante ao seu objeto de pesquisa (YIN, 2001), sendo, por este motivo, muito utilizado no campo das ciências sociais aplicadas, como no caso da administração das organizações.

Ocorre que, para que um estudo de caso tenha validade e se amolde aos preceitos rigorosamente científicos que devem nortear qualquer pesquisa ou trabalho de campo, é necessário que o mesmo seja detalhadamente planejado, além de conter suas etapas de realização previamente definidas. Deve, ainda, conter a previsão dos instrumentos que utilizará, seja na coleta, seja na análise dos dados.

Atendendo a todos estes requisitos, pode-se dizer que existe um protocolo para o estudo de caso em questão.

De acordo com Yin (2001):

\footnotetext{
Um protocolo para o estudo de caso é mais do que um instrumento. O protocolo contém o instrumento, mas também contém os procedimentos e as regras gerais que deveriam ser seguidas ao utilizar o instrumento. É desejável possuir um protocolo para o estudo de caso em qualquer circunstância, mas é essencial se você estiver utilizando um projeto de casos múltiplos. (p. 89).
}

$\mathrm{Na}$ esteira do raciocínio do autor, denota-se que o protocolo para estudo de caso se destina, basicamente, a orientar o pesquisador sobre como conduzi-lo, aumentando de maneira considerável a confiabilidade dos resultados finais por ele obtidos e de seu trabalho como um todo.

Yin (2001) ainda ensina que o protocolo para o estudo de caso deverá sempre apresentar as seguintes seções:

\footnotetext{
* Uma visão geral do projeto do estudo de caso (objetivos e patrocínios do projeto, questões do estudo de caso e leituras importantes sobre o tópico que está sendo investigado).
} 


\footnotetext{
* Procedimentos de campo (credenciais e acesso aos locais do estudo de caso, fontes gerais de informações e advertências de procedimentos).

* Questões do estudo de caso (as questões específicas que o pesquisador do estudo de caso deve manter em mente ao coletar os dados, uma planilha para disposição específica de dados e as fontes em potencial de informações ao se responder cada questão).

* Guia para o relatório do estudo de caso (resumo, formato de narrativa e especificação de quaisquer informações bibliográficas e outras documentações). (p. 89-91).
}

Para o autor, os tópicos acima transcritos demonstram, por si mesmos, porque o protocolo para o estudo de casos tem tanta importância, uma vez que eles, além de lembrarem o pesquisador sobre o tema no qual a pesquisa deverá estar centrada, ainda o forçam, mediante sua simples elaboração, a antecipar vários problemas, inclusive sobre como os relatórios do estudo deverão ser preenchidos e completados. Essa premeditação será de extremo auxílio ao desenrolar do projeto, ajudando inclusive a se evitar equívocos.

Lançadas todas estas necessárias considerações sobre o protocolo para o estudo de caso de Yin (2001), é importante ressaltar que o presente trabalho também possui o seu protocolo, o qual funcionou como um guia orientador de todos os procedimentos adotados para a conclusão da pesquisa.

Desta forma, em linhas gerais, o protocolo para o presente estudo de caso foi estruturado de acordo com as próprias etapas necessárias para a confecção da pesquisa, a qual se dividiu em duas fases distintas: I - a fase preliminar e II - a fase da coleta de dados, análise, discussão e conclusão do trabalho, propriamente dito.

Logo abaixo, segue uma síntese de como foram subdividas, em ordem cronológica e seqüencial, as fases necessárias para a realização desta dissertação:

\section{I - FASE PRELIMINAR:}

a) Definição do tema pesquisado e análise prévia de sua viabilidade e dos recursos necessários (gastos com aquisição de livros e com transporte, por exemplo), para o seu deslinde;

b) Aceitação do tema pela professora orientadora da pesquisa;

c) Busca por material bibliográfico (livros, artigos acadêmicos, simpósios, dissertações de mestrado e teses de doutorado com temas afins), que tornasse viável o trabalho a ser realizado;

d) Levantamento do material encontrado e sua revisão bibliográfica; 
e) Realização de contatos prévios com a direção de várias organizações atuantes na área da saúde (e geradoras de RSS) na cidade, com o fito de definir quais poderiam ser objeto do estudo, bem como quais delas estariam abertas ou dispostas a fornecer as informações necessárias para a pesquisa;

f) Confecção e envio de ofício ao Secretário Municipal da Saúde, a fim de solicitar autorização para coleta de dados das instituições municipais de natureza pública;

g) Qualificação do pesquisador perante sua banca examinadora, a fim de se auferir sugestões sobre a forma do trabalho, sua abrangência e o modo como a pesquisa deveria se guiar.

II - FASE DA COLETA, ANÁLISE E DISCUSSÃO DOS DADOS E CONCLUSÃO DO TRABALHO:

a) Escolha e confirmação das organizações objeto do estudo;

b) Coleta dos dados, por meio de:

- entrevistas estruturadas com diretores, gerentes e pessoal de nível operacional (inclusive terceirizados) que trabalham cotidianamente com resíduos de serviços de saúde, nas instituições analisadas;

- visitas pré-programadas e pré-agendadas às instalações das referidas organizações de saúde, com o fito de observar, conhecer, fazer anotações e realizar apontamentos quanto à sua infra-estrutura e capacidade de gerenciamento de resíduos (incluindo tratamento, acondicionamento, transporte interno e destinação final), de acordo com o previsto pelas normas vigentes.

c) Compilação dos dados coletados;

d) Análise e discussão dos dados obtidos;

e) Conclusão do trabalho e encerramento da dissertação;

f) Depósito da dissertação;

g) Defesa da dissertação.

Definidas e seqüenciadas todas as etapas necessárias para definição, realização e término do estudo, tem-se que o protocolo do presente estudo de caso, de acordo com a própria definição de Yin (2001), engloba seqüencialmente várias das etapas previstas tanto na fase preliminar do 
trabalho, quanto na fase da análise, coleta e discussão dos dados e conclusão do trabalho (acima expostas e enumeradas), com os seguintes destaques:

$1^{\circ}$ ) Quando da realização da coleta dos dados (feita através de entrevistas de profundidade e de visitas às instalações das organizações pesquisadas, com especial destaque aos setores responsáveis pela geração, acondicionamento, tratamento, transporte e destinação final dos RSS), esta foi acompanhada de um planejamento prévio baseado na própria teoria (e nas obras constantes das referências bibliográficas) em que se baseou a pesquisa.

$2^{\circ}$ ) As visitas realizadas observaram um roteiro pré-programado, onde todas as dificuldades encontradas pelo pesquisador (necessidade de autorização por escrito em algumas unidades, imposição para que o trabalho passasse primeiro por um comitê de ética, dificuldades em encontrar o pessoal responsável por meio de contatos telefônicos e de designar datas e horários em que os mesmos estivessem disponíveis para conceder entrevistas, etc.), foram devidamente registradas em um caderno transformado em diário de visitas.

$3^{\circ}$ ) As entrevistas basearam-se todas no levantamento bibliográfico, tendo sido conduzidas com técnicas de observação ${ }^{18}$ inspiradas na própria teoria e na experiência prévia do pesquisador. Deste modo, é certo que as entrevistas que foram realizadas visaram constatar como ocorria o gerenciamento dos RSS nas instituições pesquisadas, com intuito de detectar eventuais diferenças entre as organizações, seja em virtude de sua própria natureza (privada, pública, parceria público-privada ou mista), seja em virtude do modo como interpretam e aplicam, no cotidiano de suas atividades, a legislação compartimentada hoje existente. De acordo com o que previamente se dispôs a ser feito, quando da coleta de dados, considerou-se informações pertinentes tanto com relação aos resíduos abrangidos pela resolução 306 da ANVISA (resíduos tratados dentro do próprio estabelecimento que os produziu), quanto com relação aos abrangidos pela resolução 358 do CONAMA (resíduos tratados fora do estabelecimento gerador).

$4^{\circ}$ ) Por fim, por se tratar de um estudo comparativo, a análise dos dados que foram colhidos, por meio do que constou nas próprias etapas acima descritas do protocolo previamente elaborado, levou em consideração apenas o que havia de mais relevante nos mesmos e que podia ser útil para a discussão e desenrolar da pesquisa, destacando-se:

- as funções exercidas e o grau hierárquico do informante dentro da organização;

\footnotetext{
${ }^{18}$ A decisão de usar determinado método de análise de dados não ocorre no vazio; em um primeiro momento obedece ao objeto de estudo com suas próprias questões, aos atores envolvidos e a certos fatores do contexto acadêmico, social, cultural, técnico e ideológico. (BOSI; MERCADO, 2004, p. 140).
} 
- a sua capacidade e autonomia para tomada de decisões envolvendo resíduos;

- o conhecimento da legislação geral por parte do informante;

- o conhecimento da legislação específica sobre RSS por parte do informante;

- a operacionalização dentro da instituição, ou seja, a aplicação desta legislação na prática;

- a capacitação do pessoal envolvido em RSS (o conhecimento técnico dos funcionários);

- o grau de satisfação dos funcionários quanto ao gerenciamento dos RSS;

- a infra-estrutura existente na instituição no que tange ao gerenciamento dos RSS;

- a importância do gerenciamento dos RSS dentro da própria instituição;

- a certificação de qualidade envolvendo os RSS;

- a integração entre os diferentes setores envolvidos (CIPA, SESMT, CCI) dentro da organização;

- a saúde ocupacional dos envolvidos (disponibilidade de equipamentos de proteção individual (EPI's), vacinas, etc.);

- a existência ou o conhecimento, por parte do informante e dos demais empregados, do Protocolo de Acidentes com Material Biológico.

\subsection{A Coleta e a Análise dos Dados}

Por se tratar de uma pesquisa qualitativa, toda a coleta dos dados se ateve às características inerentes a este tipo de pesquisa, ou seja, além da realização de visitas préprogramadas para conhecer as instalações e toda a infra-estrutura das organizações no que tange ao gerenciamento de RSS, privilegiou-se também as entrevistas de profundidade, com poucas (porém representativas) pessoas dentro de cada instituição, e se utilizou, ainda, de técnicas projetivas e inferências na análise dos resultados obtidos.

A pretensão inicial foi a de realizar as entrevistas (cujo roteiro foi previamente definido no trabalho e pode ser visto no Apêndice A), junto a pelo menos três pessoas de cada um dos três graus hierárquicos diferentes passíveis de serem identificados nas organizações pesquisadas (por exemplo, diretoria, gerência e empregados de nível operacional), totalizando assim nove pessoas em cada caso do estudo, mas, dificuldades encontradas quando da coleta destes dados pelo pesquisador acabaram por limitar o número de entrevistados em três funcionários por cada organização, o que, de forma alguma comprometeu os resultados finais obtidos, uma vez que as informações levantadas acabaram se mostrando por demais suficientes para se atingir os 
objetivos propostos pelo trabalho ${ }^{19}$, ainda mais porque houve a realização de uma entrevista complementar, não prevista inicialmente, com a gerente de resíduos da Secretaria Municipal da Saúde de Ribeirão Preto, Dra. Marlene Duarte Mendes (a qual autorizou expressamente a divulgação de seu nome, conforme consta nos anexos).

Assim, esquematicamente, a metodologia utilizada na coleta dos dados do trabalho pode ser resumida como mostrado na figura 8.

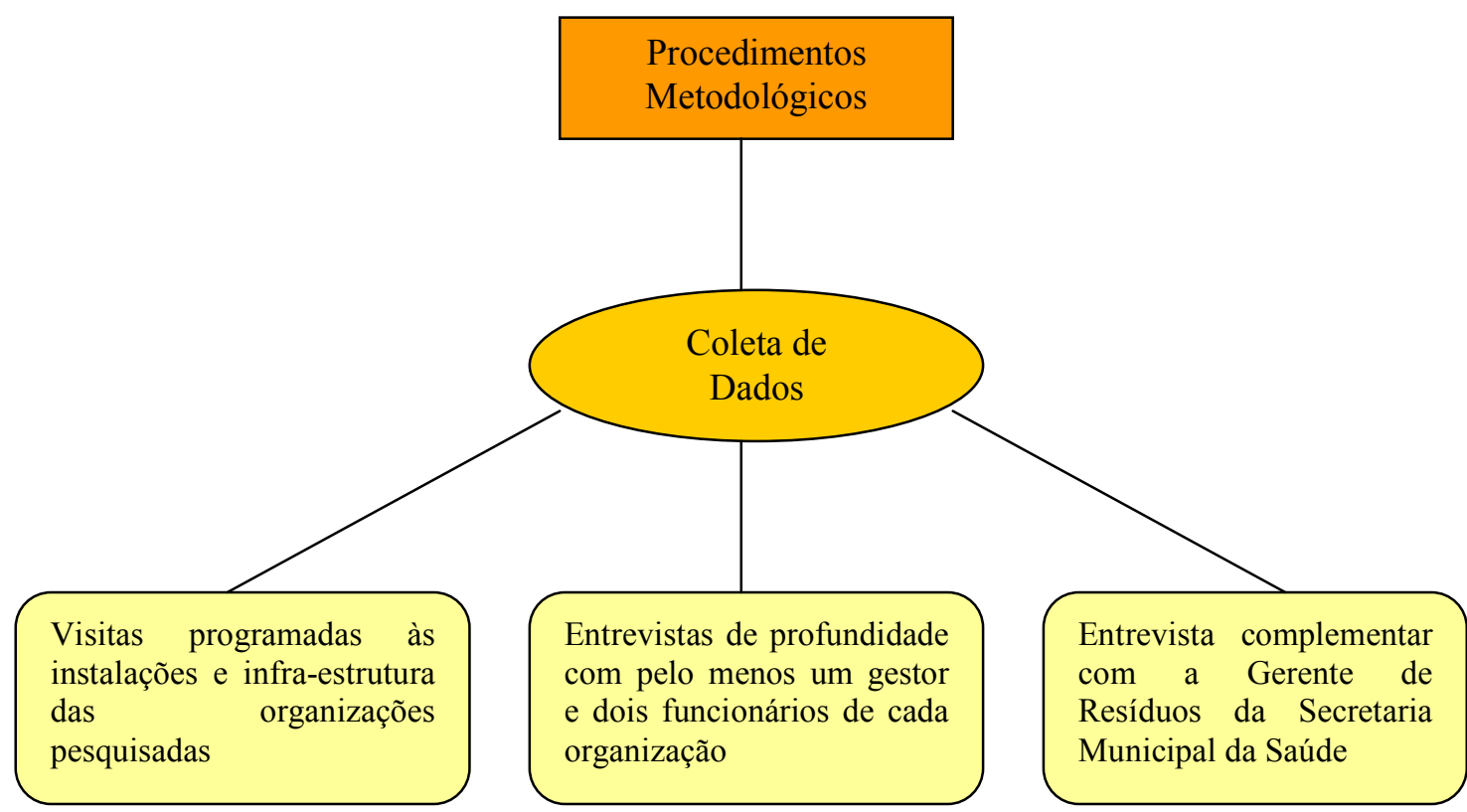

Fonte: elaborado pelo autor.

Figura 8: metodologia para coleta dos dados

Com efeito, a aplicação das questões, quando da realização das entrevistas, foi orientada pelos objetivos (geral e específicos) traçados, encontrando-se o tema, o problema de pesquisa e as hipóteses totalmente inter-relacionadas com as perguntas formuladas.

Importante destacar que houve a preocupação para que o total de perguntas e respostas não ultrapassasse a média de cinco laudas para preenchimento, evitando-se assim questionários

\footnotetext{
${ }^{19}$ As dificuldades enfrentadas pelo pesquisador quando da coleta dos dados, inclusive a justificativa para que fosse entrevistado um número mais limitado de pessoas por cada organização, são objeto de tópico próprio, dentro deste mesmo capítulo.
} 
longos, observando-se também a lógica e a progressão natural nas questões, numa seqüência lógica e ordenada, onde se partiu dos itens mais simples para os mais complexos.

Procurou-se ainda aplicar questões concisas, sucintas, claras e não ambíguas, considerando-se o nível intelectual e de formação técnica do informante e evitando o pesquisador sugerir qualquer tipo de resposta ou perguntas em que o entrevistado responda com indícios, suposições ou palpites. Na linha de aplicação das indagações, evitou-se o uso de linguagem excessivamente rebuscada ou diferente daquela utilizada cotidianamente pelo entrevistado,

É certo que todos estes cuidados visaram à obtenção de dados úteis ao desenvolvimento do estudo.

Mister se faz destacar, ainda, que havia a predisposição do pesquisador de se elaborar questões complementares e procurar novamente os entrevistados, caso as respostas para as perguntas inicialmente elaboradas demonstrassem, quando feita sua compilação e discussão, serem insuficientes ou inconclusivas para a conclusão do trabalho, de forma a se aumentar assim a capacidade de conhecimento do objeto avaliado. De todo modo, esta providência não se fez necessária, demonstrando que os dados colhidos inicialmente foram mais do que suficientes para que se alcançassem os objetivos almejados.

Importante frisar, finalmente, que quando acabou a fase da coleta dos dados, restou ao pesquisador "o trabalho de tabulação, de elaboração de gráficos, quadros, mapas, estatísticas para as análises, interpretações e conclusões de caráter indutivo.”(RUIZ, 1992, p. 52).

\subsection{As Etapas da Pesquisa Realizada}

As etapas da pesquisa que compuseram o trabalho seguiram estritamente o roteiro elaborado no protocolo deste estudo de caso, cujas fases, divididas em dois grandes grupos (fase preliminar e fase da coleta, análise e discussão dos dados), foram apresentadas em tópicos devidamente reunidos em sua seqüência cronológica, transcritos no sub-capítulo 4.2.1 (“O Protocolo para o Estudo de Caso").

De todo modo, no que concerne às algumas de suas etapas principais (como a revisão bibliográfica, a realização das entrevistas e das visitas programadas, e a elaboração e finalização da dissertação), algumas considerações ainda podem ser feitas:

A revisão bibliográfica, por exemplo, que foi desenvolvida desde o início do ano de 2007 (e continuou, ainda que em escala menor, praticamente até o término do trabalho), 
abrangeu, dentre todos os temas e tópicos de interesse para a pesquisa (como, por exemplo, a gestão de instituições de saúde e o gerenciamento de resíduos sólidos), todo um levantamento prévio das legislações federal, estadual e municipal relativas aos RSS, bem como todo o aparato normativo existente sobres resíduos, incluindo portarias, resoluções e enunciados de autarquias e órgãos da administração pública direta e indireta.

Quanto à coleta dos dados (que incluiu a realização das entrevistas e as visitas programadas dentro das instalações de cada instituição), a estimativa inicial de tempo apresentada na qualificação do discente não pôde se concretizar devido a algumas dificuldades que se mostraram maiores ou menores, dependendo de qual fosse a organização pesquisada. Estas dificuldades serão descritas de maneira pormenorizada no sub-capítulo que segue, referente às limitações metodológicas.

\subsection{Limitações da Pesquisa}

Ao longo da realização da pesquisa, notadamente na fase da coleta de dados, o pesquisador deparou-se com algumas dificuldades gerais (observadas, ainda que em maior ou menor grau, em todas as organizações estudadas) e outras específicas (particulares de cada organização pesquisada), que acabaram fazendo com que esta fase se estendesse um pouco além do que fora inicialmente planejado. Referidas dificuldades, que por motivos didáticos serão aqui designadas por limitações da metodologia, encontram-se resumidamente enumeradas nos itens que seguem:

\subsubsection{As Limitações Metodológicas Propriamente Ditas}

Entre os problemas encontrados em todas as organizações pesquisadas, ainda que em graus maiores ou menores, na coleta de dados, destacam-se os seguintes:

\subsubsection{O Gerenciamento de Resíduos no Dia-a-Dia: Um Processo Contínuo}

Quando da qualificação do pesquisador, houve a sugestão de que, na fase da coleta dos dados, fossem acompanhadas, dentro de cada organização, todas as fases do gerenciamento de RSS, que incluiriam as peculiaridades de cada uma delas no tocante à sua própria geração, seu 
acondicionamento, o transporte interno, o tratamento (no caso dos resíduos que a legislação estabelece que devam ser tratados dentro do próprio hospital) e sua disposição final.

Ocorre que, quando visitadas estas organizações, observou-se que todas as etapas acima mencionadas, envolvidas no gerenciamento de resíduos de cada organização, se constituem em processos contínuos, os quais, de acordo com Slack, Chambers e Johnston (2002):

\footnotetext{
Normalmente, operam por períodos de tempo muito mais longos. Às vezes, são literalmente contínuos, no sentido de que os produtos são inseparáveis, e produzidos em um fluxo ininterrupto. Também podem ser contínuos pelo fato de a operação ter que suprir os produtos sem uma parada. Processos contínuos muitas vezes estão associados a tecnologias inflexíveis, de capital intensivo com fluxo altamente previsível. (2002, p. 130-131).
}

Assim, quando se diz que o gerenciamento de resíduos é um processo contínuo dentro das organizações de saúde, significa que a geração de RSS ocorre ao longo do dia, dentro dos consultórios, laboratórios, salas de curativo e outras dependências delas, sem previsão ou hora marcada (eis que esta produção é decorrente dos próprios serviços prestados no dia-a-dia das referidas instituições), da mesma forma que ocorre com o seu conseqüente acondicionamento, transporte, tratamento (se for o caso) e destinação final. Não bastasse, qualquer ordem ou determinação da gerência ou direção do hospital, via de regra, não tem dia ou hora certa para ocorrer, exceção feita à algumas reuniões, que podem ou não serem pré-designadas.

A única exceção deve ser feita com relação à coleta, seja ela interna (efetuada pelo pessoal da limpeza) ou externa (caminhões coletores), tendo sido observado nas organizações que esta tem horários e, quando o caso, dias e freqüência certas em que ocorre (e, neste caso, ela pôde ser acompanhada de perto pelo pesquisador).

De todo modo, a dificuldade retro apontada não se consistiu num empecilho insuperável, eis que não comprometeu o resultado e nem os dados que foram obtidos, tendo sido compensada por visitas previamente agendadas pelo pesquisador (que ocorreram nos mesmos dias em que foram realizadas as entrevistas), onde foram conhecidas, verificadas e anotadas todas as instalações das organizações pertinentes aos RSS, tais como: consultórios médicos e odontológicos, laboratórios, salas de raios $\mathrm{X}$, corredores onde o transporte de resíduos é feito, salas que continham auto-clave, depósitos para abrigo dos resíduos até a coleta final, escritórios dos administradores, etc.

\subsubsection{A Questão das Fotografias}


Apesar de praticamente todos os entrevistados (à exceção de um, na fundação) terem autorizado expressamente a divulgação, na pesquisa, de seus dados profissionais e de todas as informações que prestaram (conforme termos de autorização que constam dos anexos), percebeuse grande relutância, inclusive dos gerentes, no que tange à tomada de fotografias das instalações visitadas. Isso ocorreu, sem exceção, em todas as organizações de saúde pesquisadas.

Em ambas as organizações particulares, foi alegado - pelo pessoal de mais alto grau hierárquico entrevistado - que a autonomia dos mesmos se restringia em fornecer as informações necessárias ao pesquisador, bem como em autorizar a realização de outras entrevistas com o pessoal de nível operacional e, no máximo, em acompanhá-lo em visita a todas as instalações que desejasse conhecer, mas que, para tirar fotos de qualquer coisa, haveria a necessidade de autorização até mesmo do conselho de acionistas (no caso da instituição privada), e da mantenedora (no caso da fundação), o que, além de levar muito tempo para ser deliberado (em meses), poderia, inclusive, resultar num indeferimento total do fornecimento de qualquer tipo de informação para a pesquisa (no caso de se o objetivo da mesma não fosse corretamente interpretado pelas pessoas responsáveis).

Quanto às unidades públicas de saúde, apesar do pesquisador contar com ofício previamente emitido pela Municipalidade de Ribeirão Preto e subscrito pela própria assessoria do Secretário Municipal da Saúde (conforme documento que consta nos anexos), autorizando expressamente que fosse feita a coleta de todos os dados e informações necessárias para a realização de seu trabalho, estas também não concordaram com a realização de fotografias, justificando sua resistência de maneira semelhante, isto é, alegando temor de que tais fotos pudessem ser utilizadas para algum fim político, ou para reportagens criticando o sistema municipal de saúde na mídia.

Importante ressaltar que, apesar de não tiradas as fotografias, não houve o comprometimento da qualidade do trabalho, eis que todas as instalações das organizações foram devidamente visitadas e conhecidas pelo pesquisador e, por este motivo, todas as descrições, apontamentos e inferências que se julgou necessário fazer sobre cada uma delas foram realizados, conforme se observa claramente no capítulo seguinte.

\subsubsection{As Informações Atinentes a Dados Financeiros}


Ainda que o presente trabalho não tenha objetivado e nem se concentrado nas questões financeiras das organizações pesquisadas, foi claramente percebida, pelo pesquisador, a relutância de qualquer um dos entrevistados (independentemente de sua função ou grau hierárquico) em lhe fornecer qualquer informação atinente, ainda que indiretamente, às finanças da organização.

Mesmo quando as entrevistas estruturadas pendiam ou acabam se voltando para alguma questão do tipo (e ainda que de maneira complementar à alguma outra informação que fosse anteriormente fornecida, ou que envolvesse resíduos), o receio dos stakeholders era latente, razão pela qual se procurou centrar ao máximo a discussão na questão dos RSS, das normas aplicáveis e de sua administração dentro da entidade.

\subsubsection{Os Contratos com as Empresas Coletoras de Lixo}

Outro problema verificado em todas as instituições pesquisadas foi o acesso aos contratos com as empresas coletoras de lixo.

Com efeito, nas organizações privadas foi alegado o mesmo problema concernente à realização das fotografias, qual seja, de que com relação aos referidos contratos, nem mesmo eles, os gerentes (pessoal com o mais alto nível hierárquico que participou das entrevistas) teriam acesso, mas somente a alta direção ou a presidência e, não bastasse, para poder ver os mesmos o pesquisador precisaria ainda da autorização dos acionistas (no caso da organização particular) e aprovação da mantenedora (no caso da fundação).

Já nas unidades públicas, foi alegado (inclusive pela gerente de resíduos da Secretaria da Saúde Municipal), que qualquer contrato ligado à Prefeitura ficaria arquivado no prédio da Secretaria da Administração, dos Negócios Jurídicos ou da Fazenda, conforme o caso (não sabendo esclarecer exatamente onde o mesmo estaria) e que o acesso a este tipo de documento somente poderia ser dado pelo próprio Prefeito ou por seus assessores diretos.

Por outro lado, quando da realização das entrevistas, foram colhidos dados pertinentes ao nome e ao porte das empresas que fazem a coleta dos resíduos, bem como relativos ao tempo de contrato de cada uma delas (e isso em todas as organizações pesquisadas), sendo certo que a divulgação de tais dados também foi devidamente autorizada, o que se mostrou demasiado suficiente para se atingir os objetivos que foram propostos. 


\subsubsection{A Quantidade de Pessoas Entrevistadas em Cada Organização}

A proposta inicial do trabalho era realizar entrevistas estruturadas que abrangessem funcionários de, ao menos, três níveis hierárquicos distintos (supervisão ou direção, gerência e operacional) dentro de cada organização, partindo-se do pressuposto preliminar de que a coleta de dados efetuada através de três pessoas diferentes, pertencentes a cada um destes três níveis hierárquicos, em cada uma das instituições pesquisadas, totalizando assim nove pessoas por cada caso de estudo, representaria um universo significativo para análise e conclusão.

Ocorre que, ainda na fase da realização dos contatos prévios necessários para a designação de data e horário para as entrevistas e visitas, percebeu-se que seria muito difícil, em qualquer das instituições pesquisadas, conseguir entrevistar nove funcionários, isso independentemente do cargo e da função dos mesmos.

Neste sentido, problemas de agenda, de horário, de atribuições e de excesso de serviço se consistiram nos principais entraves que tiveram que ser vencidos pelo pesquisador.

Alguns funcionários procurados alegavam, simplesmente, não poder dispor sequer de meia hora do seu dia para a concessão de entrevistas, outros, cujas funções interessavam à pesquisa sobre gerenciamento de resíduos, encontravam-se de férias, afastados, de licença médica ou em cursos ou constantes reuniões de trabalho, em todas as vezes que ocorreu o comparecimento pessoal do pesquisador na organização.

Por outro lado, a alta diretoria ou presidência executiva das entidades privadas se mostrava praticamente inacessível (além de não trabalharem diretamente com o RSS, deixando esta parte, inclusive envolvendo eventuais decisões ou o traçado de novas diretrizes, com o pessoal da gerência ${ }^{20}$ da área).

Da mesma forma, não foi possível conseguir espaço diretamente na agenda do Secretário Municipal da Saúde, mas, em contrapartida, conseguiu-se entrevistar a gerente de resíduos da mencionada Secretaria Municipal, conseguindo-se assim informações complementares ${ }^{21}$ que se mostraram muito úteis para a concretização do trabalho.

Assim, para não prejudicar o trabalho científico realizado e, ao mesmo tempo, não tornar inviável a pesquisa por insistência demasiada ou imposição do número de pessoas a serem

\footnotetext{
${ }^{20}$ Importante destacar que, em cada uma das organizações pesquisadas, foi ouvido ao menos um gerente ou gestor diretamente responsável pela área de resíduos de serviços de saúde.

${ }^{21}$ Tal entrevista não estava inserida nas pretensões iniciais do pesquisador e nem presente do protocolo inicial do estudo de casos.
} 
ouvidas dentro de cada uma das organizações, uma vez que as informações colhidas deveriam abranger tanto gestores quanto profissionais responsáveis pela produção, acondicionamento, coleta interna, tratamento, armazenamento e transporte de RSS, intentou-se estabelecer um número mínimo de, ao menos, três entrevistados por instituição (um gerente e dois funcionários operacionais, ainda que terceirizados), solução esta que se mostrou mais viável, na prática, quando da coleta dos dados.

Saliente-se que todos os entrevistados (à exceção de um), assinaram os termos de autorização que lhes foram previamente apresentados pelo pesquisador, anuindo assim, verbal e expressamente, com a divulgação de seus dados (cargo e função, por exemplo) e dados da instituição que representavam no presente trabalho, bem como de todas as informações e números que forneceram (todos os termos de autorização dos entrevistados encontram-se anexos no final do trabalho).

\subsubsection{Dificuldades da Coleta de Dados nas Organizações Pesquisadas}

Além das dificuldades gerais encontradas (em maior ou menor intensidade) em todas as organizações pesquisadas - as quais foram devidamente expostas nos tópicos anteriores - o pesquisador deparou-se também, quando da coleta dos dados, com algumas dificuldades específicas em cada uma das instituições, a maior parte delas referente à falta de tempo na agenda dos gestores para se conseguir marcar datas e horários para as entrevistas.

A seguir serão especificados, em cada uma das organizações objeto do estudo, os obstáculos que tiveram que ser vencidos e, conseqüentemente, o número de contatos telefônicos e de visitas que tiveram que ser realizadas, para que se pudesse realizar toda a coleta dos dados:

\subsubsection{No Posto de Saúde Municipal}

Dentre as cinco Unidades Básicas Distritais de Saúde (UBDS) existentes em Ribeirão Preto, a pretensão inicial do pesquisador era realizar a pesquisa com a UBDS Castelo Branco, responsável pela área lesta da cidade.

Para tanto, a primeira providência do pesquisador, ainda no mês de março de 2008, foi oficiar formalmente a Secretaria da Saúde Municipal, solicitando autorização para que a coleta 
dos dados fosse realizada em uma das unidades públicas municipal. O ofício foi então protocolizado na data de 06.03.2008.

Em 18.03.2008 foi obtida uma resposta, também em forma de ofício, emitido pelo Dr. Hemil Riscalla, assistente do então Secretário Municipal da Saúde, autorizando o pesquisador a realizar toda a coleta de dados que necessitasse, na unidade de saúde municipal que fosse de seu interesse.

Munido de tal documento, na data de 02.07.2008 o pesquisador compareceu pessoalmente na UBDS Castelo Branco e conversou com seu gerente, expondo todos os objetivos da pesquisa e indagando acerca de funcionários disponíveis, bem como sobre datas e horários em que poderia realizar as entrevistas e visitas programadas no seio da instituição, a fim de conhecer cada etapa do gerenciamento de resíduos.

Ocorre que, tal pessoa não se mostrou muito interessada, alegando excesso demasiado de serviço e de atribuições, pedindo na seqüência para que uma cópia do ofício, bem como do projeto de pesquisa, fosse deixada em sua mesa. Pediu também para ver as perguntas que iriam ser feitas, pleiteando para que fosse deixada também cópia do que entendeu ser um questionário, para que fosse respondido em algumas semanas, conforme disponibilidade do seu pessoal.

Quando explicado que não se tratava de pesquisa com dados quantitativos, razão pela qual não se poderia, simplesmente, deixar um questionário para respostas a posteriori, mas sim de que a presença do pesquisador era ali necessária para realização de entrevistas estruturadas, cujas perguntas seguiriam apenas um roteiro, mas poderiam surgir questões complementares conforme o rumo das informações fornecidas, o gerente falou-lhe então para deixar cópias de todos os documentos e os números pessoais do telefone do pesquisador, que dentro de duas ou três semanas ele entraria em contato, marcando as datas.

Passadas cerca de três semanas, sem contato do gerente, o pesquisador telefonou algumas vezes para a referida unidade, nos dias 29, 30 e 31 de julho, mas não conseguia falar com o mesmo.

Assim, compareceu pessoalmente novamente naquela unidade no dia 04.08.2008, abordando pessoalmente o gerente, mas o mesmo alegara que até aquela data não conseguira nem analisar o ofício e nem ler o projeto, dizendo que houve campanha e eleição nas semanas anteriores para representantes dos funcionários em órgão sindical, o que teria atrapalhado a rotina 
da unidade. Ficou de entrar em contato novamente no prazo de uma semana, o que mais uma vez não ocorreu.

Após outra série de contatos telefônicos infrutíferos, entre os dias 18 e 20 de agosto, o pesquisador mais uma vez compareceu naquela unidade, no dia 21.08.2008, conseguindo falar mais uma vez com o gerente, o qual disse que realmente, a única coisa que poderia fazer era pedir pro seu pessoal responder as perguntas ao longo dos dias e das pausas do serviço e que fosse deixado ali, por escrito, o que teria que ser respondido. Mais uma vez lhe sendo esclarecido que não era assim que funcionava, o gerente disse então que nada mais poderia fazer, sugerindo ao pesquisador que procurasse então outra unidade municipal para realização de sua pesquisa.

E assim foi feito. Iniciando novamente os contatos com a rede municipal de saúde, em 22.08.2008 o pesquisador contatou a gerência da UBDS Central (a maior, mais antiga e mais abrangente unidade de saúde pública da cidade), por telefone, designando data para conversar pessoalmente com sua gerente, qual seja, 01.09.2008, ocasião em que passou toda a manhã explicando sobre o projeto de pesquisa, seus objetivos e os dados que deveriam ser coletados.

$\mathrm{Na}$ semana seguinte, em data (09.09.2008) e horário previamente agendados, o pesquisador realizou sua primeira entrevista (com funcionária responsável pela limpeza dos resíduos), naquela instituição, a mesma que, na seqüência, o acompanhou em visita prévia a todas as instalações do prédio.

Pouco mais de uma semana depois (19.09.2008), realizou-se a entrevista com a gerente daquela unidade, a qual realizou outra visita acompanhada com o pesquisador pelos corredores, setores e departamentos daquela organização, autorizando a realização de anotações e apontamentos.

$\mathrm{Na}$ mesma data, agendou-se para a semana seguinte a realização da última entrevista, com outra funcionária da limpeza, Sra. Valquíria Cristina Flores, a qual foi levada à cabo dia 24.09.2008, encerrando-se assim a fase da coleta dos dados num dos quatro casos objeto do estudo, qual seja, o posto de saúde municipal.

\subsubsection{Na Organização Privada}

A maior dificuldade verificada quando da realização da pesquisa na organização privada não foi o número de vezes que o pesquisador teve que se dirigir ao local para realizar entrevistas 
ou terminar sua coleta de dados, mas sim encontrar algum hospital particular, na cidade, que estivesse disposto a participar da pesquisa ou fornecer algum tipo de informação para o trabalho.

Com efeito, os contatos prévios com várias instituições de saúde privadas da cidade começaram a ocorrer, por e-mail, já no mês de maio de 2008.

Esta primeira forma de contato (Internet) não se mostrou promissora, eis que os e-mails enviados, mesmo após transcorridas semanas, acabavam não sendo sequer respondidos.

Começou-se então uma segunda fase de contatos, no mês de junho de 2008, por meio de telefone, onde, após se ligar para praticamente todas as organizações privadas da cidade, foi obtida uma resposta positiva de pelo menos uma delas: o Hospital São Francisco, ocasião em que foi agendada uma visita prévia (para esclarecimentos iniciais), do pesquisador com um dos membros da direção da referida empresa.

Assim, o primeiro contato pessoal com a instituição ocorreu em 04.07.2008, quando, após longa conversa com um de seus diretores, este lhe disse que passaria o caso para a direção do hospital analisar e que, em cerca de trinta a quarenta dias dali, alguém entraria em contado com o pesquisador.

Transcorrido o prazo máximo e não tendo recebido ainda e-mail ou telefonema do hospital, o pesquisador realizou nova série de contatos telefônicos, entre os dias 20 a 22 de agosto, conseguindo novamente conversar com o diretor que inicialmente lhe atendera, o qual disse que a direção do hospital havia autorizado a pesquisa e a divulgação dos dados da própria instituição fornecendo-lhe na seqüência os telefones e ramais das pessoas que lhe concederiam as entrevistas.

Em contatos telefônicos posteriores com a gerência (entre os dias 25 a 27 de agosto), foram agendadas duas datas: 11.09.2008 (para realização da visita programada à sede e a todas as demais instalações da organização - onde pôde ser acompanhado de perto várias atividades envolvendo resíduos) e 12.09.2008 (para realização das entrevistas estruturadas com três funcionárias do hospital).

Assim, nos dias e horários designados, e dentro de um clima organizacional extremamente amistoso e solícito, foram realizadas a visita e as entrevistas, concluindo-se assim esta fase da pesquisa no tocante à coleta dos dados em uma organização privada.

\subsubsection{Na Fundação}


No Hospital Sociedade Portuguesa de Beneficência (organizado na forma de fundação privada sem fins lucrativos), o primeiro contato telefônico ocorreu ainda no mês de abril de 2008 (o hospital não possui site institucional e nem blog na Internet), tendo, após mais dois contatos, se conseguido conversar diretamente com a então gerente de resíduos da instituição.

Em 05 de maio de 2008, o pesquisador compareceu pessoalmente na sede daquela organização pela primeira vez, ocasião em que deixou, conforme lhe fora solicitado, uma cópia de seu projeto para análise. A pessoa responsável pela gerência de resíduos lhe pedira então um prazo de duas ou três semanas para conversar com a diretoria e conseguir aprovação para divulgação dos dados e informações desejados.

Transcorrido cerca de um mês, o pesquisador entrou novamente em contato com o hospital, via telefone, mas não conseguiu conversar diretamente com a gerente que inicialmente lhe atendera.

Após aguardar-se mais um mês, telefonou-se outra vez para o hospital, dia 28.07.2008, ocasião em que, após conversar com as mais variadas pessoas, dentre secretárias, telefonistas e assistentes de direção, lhe fora passado para conversar com o Sr. Jamiro Marques, técnico de segurança do trabalho.

Naquela ligação, o Sr. Jamiro explicou ao pesquisador que a então gerente de resíduos, com quem se estava mantendo contato desde o $1^{\circ}$ semestre de 2008 e que ficara responsável por conseguir a aprovação do trabalho perante a diretoria do hospital, havia se desligado do quadro funcional da instituição e que, Jamiro, agora era o responsável por todas as atribuições envolvendo RSS dentro da entidade.

O pesquisador então lhe explicou que estava mantendo contato com a antiga responsável, inclusive já tendo deixado cópia do seu projeto com a mesma para análise, esclarecendo ainda os pontos da pesquisa e as informações que precisava que fossem coletadas. $\mathrm{O}$ Sr. Jamiro então se comprometeu a conseguir, junto à diretoria do hospital, o mais breve possível, uma posição acerca do trabalho, anotando seus dados e dizendo para o pesquisador voltar a entrar em contato, dali quinze dias.

Em 15.08.2008, o pesquisador então tornou a ligar para o hospital, desta vez tendo conseguido falar diretamente no ramal do Sr. Jamiro, que então lhe disse que havia conseguido a autorização para a entrevista (que acabou sendo realizada com ele próprio), bem como para 
fornecimento dos dados que se necessitasse, exceto qualquer coisa relacionada às finanças do hospital.

A entrevista foi então realizada no dia 28.08.2008, com o Sr. Jamiro (chefe do setor de segurança do trabalho e, desde o $2^{\circ}$ semestre de 2008, de todas as questões envolvendo resíduos no hospital) e com o outro funcionário que, junto com ele, compõe o setor (sendo certo que este último foi o único de todos os entrevistados que não autorizou a divulgação de seus dados pessoais na pesquisa e nem assinou o termo de consentimento).

Naquele mesmo dia, entre as $15 \mathrm{~h} 00$ e as $18 \mathrm{~h} 00$, também se concretizou a visita programada a todos os setores, corredores e instalações do hospital, sempre com a companhia do Sr. Jamiro.

\subsubsection{Na Unidade Municipal Parceira do Estado e da USP}

O primeiro contato com o Centro de Saúde Escola do Bairro Sumarezinho também ocorreu via telefone, ainda no $1^{\mathrm{o}}$ semestre do ano de 2008. Apesar disso, a coleta dos dados na referida instituição somente se findou no mês de dezembro de 2008 , fazendo com que a mesma fosse a última de todas as organizações pesquisadas, prorrogando assim a data de conclusão do próprio trabalho, presente no planejamento inicial contido no protocolo do estudo de caso.

Isso se explica, em parte, pela própria constituição sui generis da referida unidade de saúde, ou seja, pelo fato da mesma funcionar no já mencionado esquema de parceria entre as mais diferentes entidades e autarquias públicas, como a Prefeitura Municipal, a USP, o Hospital das Clínicas da Faculdade de Medicina de Ribeirão Preto e a FAEPA.

Assim, foi descoberto empiricamente que, por haver este variado número de organizações públicas que atuam dentro da referida instituição, existem uma série de entraves formais a serem superados para a concretização de qualquer trabalho de cunho científico naquela unidade, inclusive havendo a dependência da aprovação de qualquer projeto discente por um Comitê de Ética devidamente constituído para tal finalidade.

Desta forma, no dia 12 de agosto de 2008 houve o primeiro contato pessoal do pesquisador com aquela unidade, ocasião em que lhe fora passado um rol de documentos (cuja cópia encontra-se presente nos anexos), os quais deveriam ser providenciados com a maior brevidade possível para que fossem apreciados pela próxima reunião mensal do Comitê de Ética, que ocorreria no mês de setembro de 2008 (estas reuniões eram mensais e se realizavam sempre 
na segunda terça-feira de cada mês). Dentre os documentos solicitados (os quais deveriam ser entregues impressos e também mediante arquivo digital, em disquete ou CD), estavam os seguintes:

$1^{\circ}$ ) uma Folha de Rosto, obtida no site www.saude.gov.br/sisnep, onde o projeto de pesquisa deveria ser previamente cadastrado, da mesma forma que o próprio pesquisador;

$2^{\circ}$ ) um Termo contendo o "de acordo" do responsável pelo local onde será realizada a pesquisa;

$3^{\circ}$ ) um Orçamento Detalhado de todo o dispêndio estimado para a realização da pesquisa;

$\left.4^{\circ}\right)$ o Projeto da Pesquisa, contendo um Termo de Consentimento Livre e Esclarecido, que deveria ser elaborado com base na Resolução nº 196/96do Ministério da Saúde;

$5^{\circ}$ ) o Cronograma de Execução da Pesquisa;

$\left.6^{\circ}\right)$ o Currículo Lattes do pesquisador.

Providenciados todos estes documentos e atendidos todos os procedimentos, foi protocolizado na data de 20.08.2008 um pedido de autorização para realização das entrevistas junto aos funcionários que trabalhavam com RSS, pedido este endereçado à Ilma. Profa. Dra. Maria Célia Mendes, Diretora Acadêmica de Ensino e Pesquisa do Centro de Saúde Escola da Faculdade de Medicina de Ribeirão Preto.

Não obstante, na data de 26.08.2008 foi protocolizado novo ofício, desta vez endereçado ao Ilmo. Prof. Dr. Laércio Joel Franco, Coordenador do Comitê de Ética e Pesquisa do Centro de Saúde Escola da Faculdade de Medicina de Ribeirão Preto da USP, solicitando que todos os documentos solicitados e providenciados fossem formalmente apreciados pelo Comitê de Ética da unidade e, assim, deferida a coleta de dados necessária para a conclusão do trabalho.

Transcorridos cerca de vinte dias, na data de 16.09.2008 foi expedida uma declaração (cuja cópia encontra-se nos anexos) subscrita pela Dra. Maria Célia Mendes, em que constava que o presente projeto de pesquisa havia sido aprovado pelo Centro de Saúde Escola, mas que deveriam ser aguardadas as questões éticas ainda a serem apreciadas pelo Comitê de Ética da unidade (cuja reunião da segunda terça-feira do mês de setembro havia sido prejudicada em virtude do presidente do referido Comitê ter faltado no dia de sua realização).

Aguardou-se então a realização de nova reunião do aludido Comitê, a qual se deu na segunda terça-feira do mês de outubro, dia 13.10.2008. 
Como resultado da referida reunião, foi emitido um ofício, datado de 15.10.2008, destinado à Professora Orientadora do trabalho, acompanhado de um parecer em que era solicitada a confecção de um novo Termo de Consentimento (em formato de convite e com a opção de anonimato do informante), bem como que fossem juntadas também as cópias dos demais Termos de Autorização das outras organizações que faziam parte da pesquisa.

$\mathrm{Na}$ data de 28.10.2008, foi protocolizado, como conseqüência, um novo requerimento endereçado ao Professor Dr. Laércio Joel Franco, em que constavam como anexos todos os documentos solicitados no mencionado parecer.

Mais uma vez se aguardou a realização da reunião mensal do Comitê de Ética, a qual se realizou no dia 11.11.2008 e, já no dia seguinte, referido Comitê expediu novo ofício (conforme cópia contida nos anexos), endereçado à Professora Orientadora do trabalho, declarando a aprovação do projeto de pesquisa - ad referendum - bem como o seu relatório final (quando concluído) e a publicação de seus resultados.

Em 18.11.2008, a Diretora Acadêmica de Ensino e Pesquisa do Centro de Saúde Escola, Dra. Maria Célia Mendes, também subscreveu um ofício, onde era externado que o pesquisador havia cumprido todas as exigências operacionais e legais exigidas por aquela unidade, razão pela qual poderia dar início, assim, à coleta dos dados necessários para a consecução do trabalho científico.

A partir de então, realizou-se alguns contatos telefônicos e pessoais com a Sra. Luzia Márcia R. Passos, responsável pelo gerenciamento de resíduos daquela unidade, agendando-se finalmente a data para a realização das entrevistas e da visita programada à todas as instalações da unidade, o que se deu em 03.12.2008, ocasião em que ocorreu o término da coleta dos dados. 


\section{RESULTADOS E DISCUSSÃO}

\subsection{O Gerenciamento de Resíduos e a Fiscalização}

É importante deixar consignado que, quando se fala em estudar quaisquer casos concretos de gerenciamento de resíduos, via de regra, o que se estuda são todas as ações relativas ao manejo destes mesmos resíduos, ações estas que devem partir de modelos de gestão previamente adotados pelos administradores responsáveis, observando-se, para tanto, o tipo de resíduo sólido gerado pela organização, bem como todas as particularidades do próprio estabelecimento e os dispositivos normativos aplicáveis ao seu tipo de atividade (posto que não se pode agir, administrar ou gerenciar de maneira contrária ao estabelecido em lei).

No caso dos resíduos de serviços de saúde (RSS), as principais etapas que envolvem o seu gerenciamento se referem à geração, segregação, acondicionamento, coleta, armazenamento (ainda que provisório, dentro da unidade geradora), transporte e destinação final. Além destas, existe outra, que também deve ser sempre considerada: a proteção à saúde pública, notadamente da localidade à qual a organização geradora pertença.

Sinteticamente, referidas etapas e suas subdivisões estão descritas no quadro 7:

\begin{tabular}{|l|l|ll|}
\hline G & Manuseio & a) & Separação ou segregação \\
E & e & b) & Acondicionamento \\
R & Descarte & c) & Coleta: interna, externa especial ${ }^{22}$ \\
E & & d) & Armazenamento \\
N & & e) & Transporte \\
C & & f) & Outros: local de apresentação dos resíduos para coleta externa e \\
I & & & \multicolumn{1}{c|}{ cuidados com o pessoal } \\
A & Tratamento & a) & Desinfecção química \\
M & (RDC 33/2003 da & b) & Esterilização a vapor (em autoclaves) \\
E & ANVISA e Resolução & c) & Esterilização por gases \\
N & 283/2001 do & d) & Inativação térmica \\
T & CONAMA) & e) & Incineração \\
O & & f) & Radiações ionizantes \\
& & g) & Uso de microondas \\
D & & h) & Uso de tocha de plasma \\
E & Destinação & a) & Aterro sanitário \\
& Final (Resolução & b) & Vala séptica \\
R & 283/2001 do & & \\
S & CONAMA) & & \\
S & & & \\
\hline
\end{tabular}

FONTE: Takayanagui in Philippi Jr. (2005, reimp. 2008).

\footnotetext{
${ }^{22}$ A coleta especial é indicada para todo tipo de resíduo de alto risco no transporte, exigindo a presença de técnicos especializados e rotinas separadas dos demais tipos de coleta (PHILIPPI JR., 2005, p. 344). Por exemplo: produtos químicos, inflamáveis e medicamentos vencidos.
} 
Assim, todas as particularidades dos procedimentos envolvidos no gerenciamento de resíduos demonstram a sua complexidade dentro do campo das ciências da administração, se consistindo num processo tão importante para qualquer gestor, quanto o próprio gerenciamento da produção ${ }^{23}$. Portanto, da mesma forma que existem "algumas classes gerais de atividades que se aplicam a todos os tipos de produção, não importa como as fronteiras funcionais foram definidas" (SLACK; CHAMBERS; JOHNSTON, 2002, p. 53), existem também, nas ciências da administração, princípios inerentes a todo o tipo de gerenciamento, que abrangem todo o tipo possível de atividades, da prestação de serviços à produção no chão de fábrica, englobando empresas privadas, sociedades de economia mista, grandes conglomerados financeiros, pequenas empresas, instituições sem fins lucrativos, fundações, profisssionais liberais de todo tipo, organizações prestadoras de serviços de saúde, etc. Daí decorre, portanto, a importância seja da gestão (campo teórico), seja do gerenciamento (aplicação prática) do manejo dos resíduos de serviços de saúde, como ocorre com qualquer outro campo ou ramo de atividades que demandem conhecimentos administrativos.

Formuladas estas necessárias considerações, tem-se que tanto a ANVISA, por meio da RDC 306/2004, quanto o CONAMA, por meio da resolução n ${ }^{0} 358 / 2005$, determinam a todas as organizações prestadoras de serviços de saúde que elaborem um Plano de Gerenciamento de Resíduos de Serviços de Saúde (PGRSS), o qual deve se constituir de um documento formal, por meio do qual sejam traçados rumos e elaboradas diretrizes dentro da instituição, relativamente à todas as ações pertinentes ao manejo dos resíduos sólidos (observando-se todas as etapas retro mencionadas envolvidas em seu gerenciamento).

Neste prisma, no tocante às organizações objeto do estudo, a única que apresentava um PGRSS devidamente estruturado e totalmente implementado (englobando $100 \%$ de suas atividades) foi o Hospital Beneficência Portuguesa (Fundação Sociedade Portuguesa de Beneficência), sendo certo que o Sr. Jamiro Marques da Cruz, técnico de segurança do trabalho do Hospital e responsável pelo gerenciamento de RSS daquela instituição, além de apresentar uma via do aludido Plano de Gerenciamento, fez questão de ressaltar o pioneirismo daquela

\footnotetext{
${ }^{23}$ De acordo com Slack et al., a função produção também possui alguns procedimentos básicos, que podem ser considerados também suas etapas primordiais, da mesma forma que ocorre com o gerenciamento de resíduos. São eles, pela seqüência: a) o entendimento dos objetivos estratégicos da produção; b) o desenvolvimento de uma estratégia de produção para a organização; c) o projeto dos produtos, serviços e processos de produção; d) o planejamento e o controle da produção e e) uma vez fechado o ciclo, o processo de aprimoramento que resulte em contínua melhoria do desempenho da produção.
} 
organização no município no que se refere à questões relativas à resíduos, meio ambiente e saúde pública.

Com efeito, esclareceu o Sr. Jamiro que o Plano de Gerenciamento de Resíduos de Serviços de Saúde do Hospital Beneficência Portuguesa foi o primeiro plano elaborado por uma organização hospitalar de porte na cidade de Ribeirão Preto (tendo sido criado no ano de 1999), com o objetivo de dar um rumo à entidade, diante do que fazer frente às principais contradições normativas existentes, as quais, segundo ele, ocorriam principalmente entre as cartilhas da ANVISA e normas do CONAMA.

O Sr. Jamiro destacou ainda que seu hospital resolveu elaborar o próprio PGRSS, em atitude pioneira no município, porque ninguém na Secretaria Municipal da Saúde sabia dar indicações precisas quando eram procurados pela mencionada fundação ou consultados sobre determinados procedimentos envolvendo os resíduos gerados na instituição.

Nesta linha de raciocínio, foi constatado que o pioneirismo da Sociedade Portuguesa de Beneficência realmente fez com que seu PGRSS se tornasse uma referência no município, eis que até mesmo seu suposto rival, o Hospital São Francisco (outra instituição objeto do presente estudo de casos), quando da realização das entrevistas, reconheceu e fez menção expressa, por meio de suas prepostas, sobre os avanços representados pelos procedimentos de gerência de RSS criados pela mencionada fundação.

Até mesmo a Secretaria Municipal da Saúde Municipal tomou como referência o PGRSS elaborado pela Sociedade Portuguesa de Beneficência quando da elaboração de seu próprio Plano de Gerenciamento de Resíduos. Esta informação foi dada em entrevista pela Sra. Marlene Duarte Mendes, gerente de resíduos da Secretaria Municipal da Saúde de Ribeirão Preto, a qual ainda esclareceu que, diante da quantidade de leis e normas hoje existentes versando a questão dos resíduos, a Prefeitura Municipal optou por seguir em sua cartilha, basicamente, o que dispõe a RDC 306 da ANVISA ${ }^{24}$ (notadamente com relação a todos os procedimentos que devem ser tomados dentro das próprias unidades no tocante aos resíduos infectantes, químicos, radioativos e recicláveis).

\footnotetext{
${ }^{24}$ A Sra. Marlene mencionou também que, com relação aos procedimentos de manejo de RSS que devem ocorrer fora dos estabelecimentos geradores, a Secretaria Municipal da Saúde procurou observar ainda a Resolução $n^{\circ} 358$ do CONAMA e, com relação à destinação final destes resíduos, o que dizem as normas da CETESB/SP.
} 
É interessante registrar que, na teoria, o PGRSS da Municipalidade somente foi concluído no ano de 2006 (portanto, com atraso de 7 anos em relação ao Hospital Beneficência Portuguesa), mas, na prática, ainda não foi implementado na totalidade das unidades que compõem a rede municipal da saúde, o que está sendo feito, segundo a gerência de resíduos da Secretaria Municipal, de maneira gradual e progressiva.

Realmente, o que se observou nas entrevistas realizadas com os gestores públicos (a gerente geral da unidade de saúde, no caso da UBDS Central, e a enfermeira responsável pelo gerenciamento dos RSS, no caso do Centro de Saúde Escola ${ }^{25}$ ), foi uma dependência muito grande, não com um órgão propriamente dito (a Secretaria Municipal da Saúde, por exemplo), mas sim com uma única pessoa, qual seja, a Sra. Marlene, gerente de resíduos da Prefeitura, seja no tocante aos procedimentos cotidianos adotados pelas unidades em questão envolvendo resíduos, seja com relação à implantação de qualquer nova prática operacional.

Finalmente, no Hospital São Francisco, foi constatado que não existe um PGRSS propriamente dito, mas, em contrapartida, existe em sua estrutura organizacional uma Comissão de Gerenciamento de Resíduos, formada por membros dos SESMT, de todos os laboratórios e do $\mathrm{CCIH}$ do próprio hospital, sendo certo que esta Comissão, em conjunto com a própria Gerência de Enfermagem da organização, é que analisa todas as decisões envolvendo práticas de manejo de RSS na entidade, bem como propõe os procedimentos e rotinas a serem adotadas no que tangem aos resíduos produzidos, mesclando assim todas as atribuições de gestão e gerenciamento dos mesmos.

Por outro lado, na obra organizada por Philippi Jr. (2005), Takayanagui destaca que um dos pressupostos essenciais para a elaboração de qualquer Plano de Gerenciamento de Resíduos de Serviços de Saúde se consiste no levantamento de dados claros e precisos acerca do volume dos resíduos gerados dentro da organização (bem como de suas características físicas, químicas e microbiológicas), uma vez que estes resíduos variam de acordo com os tipos de atividade e com a quantidade e variedade de serviços oferecidos pelo hospital, razão pela qual estas informações são imprescindíveis para o manejo adequado de qualquer tipo de RSS.

\footnotetext{
${ }^{25}$ O Centro de Saúde Escola da Faculdade de Medicina de Ribeirão Preto, apesar de seguir a cartilha da Gerência de Resíduos da Secretaria da Saúde Municipal e não possuir um PGRSS próprio (no sentido estrito da palavra), possui um "Mapa de Resíduos" (material que fora vislumbrado pelo pesquisador), elaborado na própria unidade e que enumera, dentre todos os cômodos existentes na planta dos prédios que compõem a organização, onde se encontram os recipientes contendo sacos de lixo pretos (utilizados para lixo comum) e sacos de lixo brancos (utilizados basicamente para acoplar material infectante).
} 
De acordo com a consagrada autora:

Em relação aos resíduos sólidos urbanos, os RSS representam de 1 a $2 \%$ do volume total gerado, tanto no Brasil com o em países europeus e norte-americanos, o que não reduz, absolutamente, a importância e a necessidade de um gerenciamento adequado e responsável pelos geradores e administradores públicos das áreas de meio ambiente e saúde, pelo potencial de risco de exposição à saúde pública e ao ambiente. (TAKAYANAGUI in PHILIPPI JR. 2005, reimp. 2008, p. 330).

Destacada a importância das informações acerca do volume de resíduos produzidos numa organização prestadora de serviços de saúde, para elaboração de seu PGRSS, saliente-se que nas entrevistas realizadas com os gestores e pessoas de mais alto escalão dentro dos casos de estudo, houve a indagação acerca destes dados, mas nem todas as unidades dispunham de tais números ou os mensuravam na mesma escala, conforme se afere do demonstrativo do quadro 8 .

Percebe-se, portanto, que as duas unidades privadas (Hospital São Francisco e Hospital Sociedade Portuguesa de Beneficência) possuem informações mais detalhadas com relação à quantidade e volume dos RSS que produzem, com relação às suas colegas da área pública, notadamente quando comparadas com a Unidade Básica Distrital de Saúde Central do Município $^{26}$, a qual, saliente-se, foi a única dentre todas as organizações pesquisadas que não possui nem um setor ou um departamento específico de resíduos, e muito menos uma pessoa responsável pelo gerenciamento dos mesmos.

\section{PERCENTUAL DE RSS EM RELAÇ̃̃O AO TOTAL DE RESÍDUOS GERADOS}

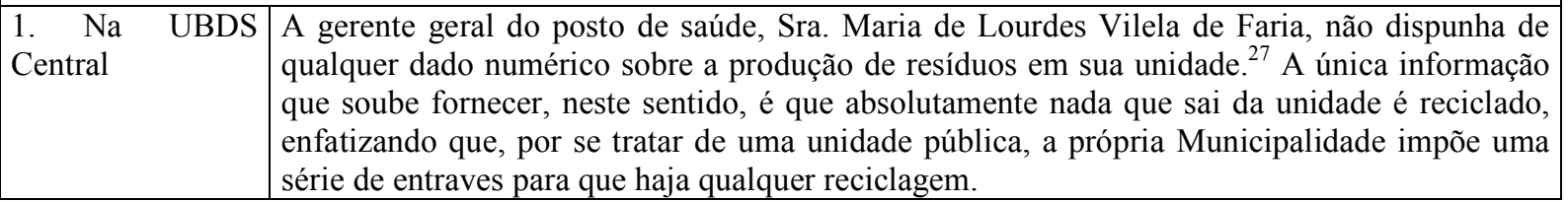

\footnotetext{
${ }^{26}$ Apesar da grande quantidade de procedimentos médicos, dentários e ambulatoriais oferecidos, bem como da vasta gama de pacientes que atende diariamente, constatou-se que a gerente do posto de saúde central não considera que administra um hospital, no sentido estrito da palavra, mas apenas uma subdivisão administrativa e operacional de um corpo sistêmico maior, que se consiste na própria Secretaria Municipal da Saúde e suas políticas. Suplementando este tipo de entendimento, destaque-se BOTAZZO (1999), para quem, uma unidade básica de saúde "é um conjunto de atribuições e competências que deverão ser exercidas sobre grupos populacionais e num certo sentido. É o lugar de uma dada ciência, um dado saber, uma tecnicalidade, uma coisa médica e medicalizada.” (p. 105).

${ }^{27}$ Mister destacar que, em entrevista, a gerente de resíduos da Secretaria Municipal da Saúde, Sra. Marlene Duarte Mendes, informou que quem efetua a pesagem dos resíduos em toda a rede municipal também é uma empresa terceirizada, chamada "Ambient", bem como que a média gerada em cada unidade é de $900 \mathrm{~kg} / \mathrm{dia}$ de RSS.
} 


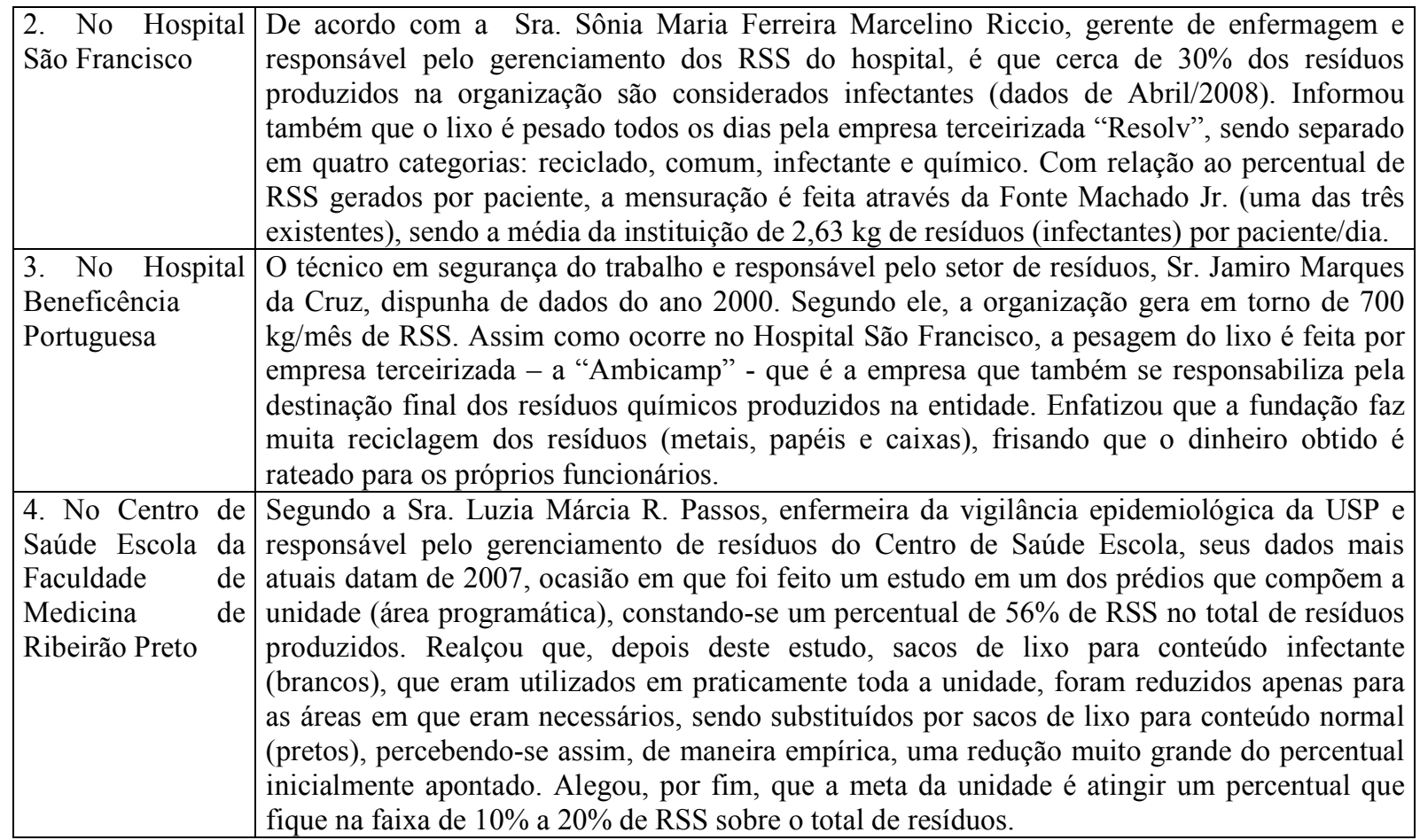

$$
\text { Fonte: elaborado pelo autor }
$$

\section{Quadro 8: Percentual de RSS em relação ao total de resíduos gerados nos estabelecimentos pesquisados}

Numa análise mais rápida e menos cuidadosa, poderia então se aferir, em princípio, que, pelo fato dos administradores das unidades públicas disporem de menos dados sobre RSS do que seus pares nas organizações privadas, os mesmos encontrariam muito mais dificuldades para elaborar ou aplicar um PGRSS e, conseqüentemente, para exercerem quaisquer funções atinentes à resíduos, possuindo muito mais obstáculos no que diz respeito à tomada de decisões e para traçar diretrizes e rumos estratégicos a serem seguidos pelas entidades que representam.

Ocorre que, numa análise mais apurada, o que se pode constatar é justamente o contrário, eis que as próprias diferenças entre a natureza e a constituição das instituições analisadas fazem com que a falta de dados mais detalhados sobre os RSS para os gerentes das unidades públicas não se constitua num entrave para o desempenho diário de suas funções de direção ou comando; pelo contrário, diminuem suas responsabilidades neste tocante, tornando suas atribuições mais fáceis, uma vez que os mesmos se transformam em meros aplicadores de ordens, procedimentos e determinações vindas da direção do poder público ao qual se encontram vinculados (no caso, a própria Secretaria Municipal da Saúde). 
Explica-se: por estarem os gerentes das unidades públicas (inclusive do Centro de Saúde Escola) subordinados, por meio de normas e princípios de direito administrativo, à Secretaria Municipal da Saúde, sua atuação, no que tange aos resíduos produzidos nas unidades que administram, limita-se basicamente e quando muito ao gerenciamento dos mesmos (no sentido de simplesmente aplicarem ou fiscalizarem a aplicação de modelos previamente definidos pela direção do órgão), enquanto que, nas organizações privadas, se pratica tanto a gestão quanto o gerenciamento sobre tudo o que diz respeito aos RSS.

Com efeito, quando de diz que nas organizações privadas pesquisadas (inclusive na Fundação), os gerentes exercem efetivamente não só o gerenciamento, mas também a gestão, quer se dizer que os mesmos não só aplicam ou fiscalizam, mas participam efetivamente da elaboração e da escolha dos modelos adotados, analisando conjuntamente com a diretoria ou com o departamento jurídico da instituição as normas existentes e a aplicabilidade das mesmas no dia a dia da organização, além de ajudarem a traçar as diretrizes, objetivos e metas no que tange aos resíduos, tudo isso sem descuidarem da implementação destes modelos de gestão. Desta forma, os gestores dos casos do estudo de âmbito privado têm participação ativa em toda a parte teórica da administração de RSS (gestão), e não só da prática (gerenciamento), não se limitando, assim, à mera aplicação e fiscalização de procedimentos e rotinas, cuja escolha não teriam tido, em teoria, qualquer participação.

Ressalte-se que a enfermeira responsável ${ }^{28}$ pelo gerenciamento dos RSS no Centro de Saúde Escola da Faculdade de Medicina de Ribeirão Preto, Sra. Luzia Márcia, em entrevista concedida, mencionou expressamente (sem prévia indução ou sugestão do pesquisador), que o que ela faz naquela unidade resume-se a práticas de gerenciamento de RSS, mas jamais de gestão dos mesmos, demonstrando assim indubitável conhecimento administrativo da significação de cada um destes conceitos.

Por outro lado, esta diferença primordial constatada (da prática tanto da gestão quanto do gerenciamento nas organizações particulares e não só deste último, como ocorre nas públicas) se evidencia muito entre as organizações pesquisadas, notadamente quando se considera a questão da fiscalização a que as mesmas se submetem (ou deveriam se submeter) por parte dos variados órgãos que regulamentam a questão dos resíduos de serviços de saúde - RSS.

\footnotetext{
${ }^{28}$ A vinculação funcional da Sra. Luzia Márcia é com a USP e não com a Secretaria Municipal da Saúde, apesar da mesma acatar ordens diretas deste órgão sobre tudo o que diz respeito aos resíduos de serviços de saúde.
} 
Neste prisma, constatou-se também que as entidades privadas (o Hospital São Francisco e a Sociedade Portuguesa de Beneficência), apesar do predomínio da fiscalização exercida pela própria Secretaria Municipal da Saúde (através dos seus setores de Fiscalização Geral, Vigilância Epidemiológica e outros), sofrem (ou podem sofrer), ainda que de maneira eventual ou mesmo raramente, visitas de representantes de órgãos, entidades e autarquias variadas, como, por exemplo, de fiscais da ANVISA, do CONAMA, da Secretaria Estadual da Saúde, do Meio Ambiente, dentre outros; além de terem que, esporadicamente, responder ofícios e pesquisas formuladas pelo Governo Federal, ABNT, Ministério da Saúde, Ministério do Meio Ambiente, Ministério do Trabalho, etc. Por óbvio, a chance dos gestores destas unidades se depararem com conflitos normativos entre estes diferentes órgãos, entidades e autarquias da administração pública direta e indireta, se torna muito grande, como inclusive já lhes ocorreu (e será devidamente debatido em tópico específico).

Já as unidades públicas (com base do relato das próprias gerentes e também do restante do pessoal entrevistado), ao contrário do que ocorre com seus pares da iniciativa privada, não sofrem uma fiscalização dispersa e intensiva por parte de autarquias ou entidades variadas pertencentes à unidades federativas ou agentes políticos diversos, mas apenas e tão somente fiscalização por parte da própria Secretaria Municipal da Saúde, sendo então constatado que este órgão, na prática, centraliza a função fiscalizadora de todos os demais agentes (ANVISA, CONAMA, Secretarias Estaduais e Ministérios Federais, etc.), nas unidades que compõem o sistema de saúde pública da cidade. ${ }^{29}$

Neste sentido, Meirelles (2007) ensina que a própria administração pública não só pode, como de fato deve fiscalizar a si própria (e, por via de conseqüência, todos os atos praticados por seus prepostos, administradores e funcionários, sejam eles de carreira, concursados ou nomeados). Este poder administrativo de auto-fiscalização é designado, conforme ensina o autor, como poder de polícia administrativa (o qual é exercido, seja de maneira exclusiva ou concorrente, pelas três esferas políticas da União), devendo ser acionado pelo poder público, ainda que preventivamente, sobre todas as atividades, atribuições e bens que afetem, mesmo que em teoria ou parcialmente, a coletividade.

\footnotetext{
${ }^{29}$ É claro que, por sofrerem uma fiscalização não menos ostensiva, mas muito mais centralizada, as unidades de saúde públicas estudadas (e, conseqüentemente, seus gestores) são muito menos suscetíveis a serem vítimas de conflitos normativos, do que seus pares na esfera privada, conforme será devidamente elucidado na conclusão do trabalho.
} 
De acordo com reconhecido mestre:

\begin{abstract}
A fiscalização hierárquica é exercida pelos órgãos superiores sobre os inferiores da mesma Administração, visando a ordenar, coordenar, orientar e corrigir suas atividades e agentes. É inerente ao poder hierárquico, em que se baseia a organização administrativa, e, por isso mesmo, há de estar presente em todos os órgãos do Executivo. São características da fiscalização hierárquica a permanência e a automaticidade, visto que se exercita perenemente, sem descontinuidade e independentemente de ordem ou de solicitação especial. É um poder-dever de chefia, e, como tal, o chefe que não o exerce comete inexação funcional. (MEIRELLES, 2007, p. 672).
\end{abstract}

Meirelles (2007) ainda complementa todo o raciocínio já exposto ao ressaltar que, para garantirem o desempenho da fiscalização pública, os superiores hierárquicos devem acompanhar sempre a execução das atividades que cabem a seus subordinados, bem como o desempenho individual de cada um, além, é claro, de verificarem o correto cumprimento da lei e das normas internas do órgão que representa, adotando, se for o caso, medidas que julgar úteis para o aprimoramento cada vez mais constante do serviço, sempre observados os limites de sua própria competência.

Desta forma, como nas unidades públicas municipais todos os modelos, decisões e orientações sobre novos procedimentos se concentram na gerência de resíduos da Secretaria da Saúde Municipal, os gerentes ou responsáveis pelos RSS das organizações analisadas acabam se esquivando de qualquer responsabilidade sobre a aplicação de leis ou normas. Mesmo a enfermeira responsável pelo gerenciamento de RSS do Centro de Saúde Escola (que demonstrou um pouco mais de conhecimento sobre procedimentos práticos da normatividade pertinente ao RSS do que sua colega gerente geral do Posto de Saúde Central), frisou em sua entrevista que qualquer modelo de gestão adotado provem necessariamente da Prefeitura Municipal.

Por seu turno, a Sra. Marlene Duarte Mendes, gerente de resíduos da Secretaria Municipal da Saúde, esclareceu que o PGRSS da Prefeitura Municipal de Ribeirão Preto adota, basicamente, a cartilha da ANVISA $^{30}$, tendo sido quase todo elaborado com base no que dispõe a RDC 306/2004. Assim, deduz-se que a fiscalização a que são submetidas as unidades municipais, basicamente, verifica se as práticas e procedimentos adotados no cotidiano operacional das mesmas (no que tange aos resíduos) estão ou não adequadas com o que dispõe a ANVISA, ainda

\footnotetext{
${ }^{30}$ Para Meirelles (2007), a Agência Nacional de Vigilância Sanitária - ANVISA - pode ser melhor definida como "Polícia Sanitária". Neste sentido, o autor considera que mencionada agência "tem como finalidade básica a proteção à saúde da população, por intermédio do controle sanitário da produção e da comercialização de produtos e serviços submetidos à vigilância sanitária, inclusive dos ambientes, dos processos, dos insumos e das tecnologias a eles relacionados" (p. 144).
} 
que existam, eventualmente, outras normas ou dispositivos legais não atendidos e nem observados por estas unidades, emanados de órgãos, secretarias ou autarquias distintas.

Isso, sem sombra de dúvidas, também acaba por beneficiar os gestores públicos no que tange ao gerenciamento de RSS em comparação com seus pares que atuam na iniciativa privada, seja nas questões atinentes à alocação de recursos para aquisição de equipamentos e acessórios previstos pelos órgãos envolvidos com o tema, seja com relação à disposição do quadro de pessoal para atendimento dos variados procedimentos operacionais, etc. Um exemplo que pode ser mencionado, neste sentido, é a questão das lixeiras com pedais.

Numa organização que presta serviços de saúde, a importância de existirem lixeiras com tampa e adicionadas a pedal, é evitar o contato manual dos trabalhadores que coletam os RSS com a tampa, descartar corretamente estes RSS e, por vezes, evitar também contatos dos animais com estes resíduos dentro da unidade. Neste sentido, o CONAMA, através de suas resoluções 5/1993 e 283/2001, determina que resíduos pertencentes ao Grupo A (resíduos com risco biológico) devem ser dispostos em sacos plásticos brancos e leitosos, resistentes e impermeáveis, com o símbolo universal da substância infectante, e colocados na lixeira de cor branca, com respectiva tampa e pedal, identificada com o símbolo respectivo.

Ocorre que, nas visitas realizadas às instalações de cada caso do estudo, constatou-se que as unidades públicas não dispunham deste tipo de equipamento na totalidade de suas dependências, ao contrário do que ocorria com as entidades privadas. Indagados nas entrevistas, ambos administradores (do Hospital São Francisco e da Beneficência Portuguesa) explicaram que tiveram que se adequar imediatamente à edição das normas que estabeleciam a aquisição deste tipo de equipamento e, conseqüentemente, buscar recursos para adquiri-los, sob pena de serem penalizados com multas e autos de infração, não só por parte do próprio CONAMA, mas também pela ANVISA (que também prevê o uso deste tipo de lixeira no texto da RDC 306/3004) e, ainda, pela própria Prefeitura Municipal. No caso das unidades públicas, por não sofrerem fiscalização direta do CONAMA ou da ANVISA, e também pelo fato de serem fiscalizadas diretamente pelo próprio poder público municipal, não houve até agora a aquisição deste equipamento de modo que se atenda à todas suas instalações (incluindo ambulatórios e consultórios), o que, de forma alguma, se mostrou matéria de preocupação para os gerentes entrevistados. OBS.: a questão das lixeiras com tampa e pedal e a legislação pertinente, será mais bem detalhada no sub-capítulo referente à estrutura física dos casos de estudo. 
De todo modo, retomando o raciocínio anterior, nas unidades privadas, foi relatado que, ainda que raramente ou de maneira eventual, elas sofrem (ou podem sofrer) visitas de fiscais do CONAMA, da ANVISA, das Secretarias Estaduais (Saúde, Meio Ambiente), além, é claro, do pessoal da própria Secretaria da Saúde Municipal. Mesmo a fundação privada sem fins lucrativos (Hospital Beneficência Portuguesa), com todo o seu pioneirismo na questão ambiental e seu Plano de Gerenciamento de Resíduos de Serviços de Saúde considerado um modelo no município, submete-se a fiscalização regular dos órgãos, autarquias e entidades retro mencionadas.

Diante de todo o exposto até aqui, restou constatado, na prática, algumas das diferenças estruturais existentes entre a própria administração pública e privada (as quais já foram levantadas anteriormente, no campo teórico do presente trabalho), que apenas confirmam os paradigmas de que para um gestor administrar bem a sua organização, deve estar sempre atualizado com a legislação e a normatividade inerentes a seu campo de atuação, uma vez que se não segui-las poderá estar sujeito à multas ou sanções que, além de lhe ocasionarem prejuízos imediatos, a médio ou longo prazo, poderá inviabilizar por completo o seu próprio negócio. Se esta premissa é verdadeira também para órgãos ou entidades públicas, que dirá para gestores de organizações privadas ou particulares, ainda mais aqueles envolvidos diretamente com questões ambientais, as quais estão praticamente impondo novos paradigmas, no mundo contemporâneo, à ciência da administração.

\subsection{A Estrutura Física e o Fluxo de Informações}

Como já exposto, o gerenciamento de RSS pressupõe fases distintas dentro da organização que os produz, como, por exemplo, segregação, descarte, coleta, transporte interno, tratamento (quando o caso), transporte externo e disposição final, cada uma delas regulamentada por leis específicas e, por este motivo, demandando alocação de recursos, disposição de pessoal capacitado e tomada de decisões por parte dos gestores e administradores, de forma que se trabalhe sempre de acordo com as normas e dispondo-se de numerário suficiente para aquisição de todo tipo de equipamento que se fizer necessário.

Desta forma, após realizadas visitas previamente programadas nas instalações das organizações e verificada a infra-estrutura de cada uma, realizou-se algumas comparações envolvendo as fases de gerenciamento de RSS. Obtidos os resultados, dentro do que interessa 
para o presente trabalho, foi dada ênfase então a um aspecto específico dentro das seguintes fases: a) segregação e descarte; b) transporte interno; c) tratamento e d) armazenagem externa.

$\mathrm{Na}$ fase de segregação e descarte, o aspecto comparado foi a presença ou não de lixeiras basculantes, com tampa e pedal, dentro das unidades. Na fase de transporte interno, o aspecto comparado foi a existência ou não de corredores internos destinados exclusivamente ao transporte de RSS. Na fase de tratamento, o aspecto comparado foi quanto a existência (ou não), em cada unidade, de três aparelhos distintos para tratamento interno de RSS: autoclaves, microondas e tochas de plasma. Por fim, na fase de armazenamento externo, comparou-se a situação dos abrigos em cada organização.

As comparações (organizadas por meio de tabelas), acompanhadas dos respectivos comentários e da legislação pertinente (se o caso), encontram-se a seguir:

a) Fase de segregação e descarte - aspecto estudado e comparado: existência ou não de lixeiras basculantes, com tampa e pedal, em todos os recintos geradores da organização. De acordo com levantamento normativo prévio, as lixeiras de uma organização prestadora de serviços de saúde, geradoras de resíduos enquadrados em um dos cinco tipos distintos previstos pela RDC n 306/2004 da ANVISA, deve dispor de lixeiras basculantes, com tampa e pedal, em todas suas salas, consultórios e laboratórios que gerem este tipo de resíduo, à exceção das salas cirúrgicas e de parto. Neste sentido, destaca-se o disposto no item 1.2.2 do Capítulo III (Gerenciamento dos Resíduos de Serviços de Saúde) da RDC 306/2004 da ANVISA: "os sacos devem estar contidos em recipientes de material lavável, resistente à punctura, ruptura e vazamentos, com tampa provida de sistema de abertura sem contato manual, com cantos arredondados e ser resistente ao tombamento" ${ }^{\text {31. }}$.

O quadro 9 demonstra o que foi constatado por meio das visitas realizadas nas instalações dos casos de estudo (e também pelas informações colhidas nas entrevistas), quanto às lixeiras.

\footnotetext{
${ }^{31}$ Como já exposto no sub-capítulo anterior, o CONAMA também prevê o uso deste tipo de lixeira, para casos de resíduos que contenham risco biológico de contaminação. Quanto à CETESB/SP, suas normas não dispõem sobre tipos de lixeiras propriamente ditas, mas se preocupam em regulamentar tudo o que diz respeito à destinação final dos RSS (após estes terem sido coletados e transportados para fora das unidades geradoras). Por seu turno, a ABNT estabelece formas e procedimentos de segregação, descarte e coleta que são utilizados como base para outras normas de órgãos distintos, como CONAMA e ANVISA. Já nas legislações municipal, estadual e federal, não foi encontrado nada especificamente sobre o tipo de lixeira que deve ser adotado dentro de organizações prestadoras de serviços de saúde.
} 


\begin{tabular}{|l|l|}
\hline $\begin{array}{l}\text { Organização } \\
\text { Pesquisada }\end{array}$ & $\begin{array}{l}\text { Possui lixeiras basculantes, com tampa e pedal, } \\
\text { em toda a unidade? }\end{array}$ \\
\hline 1. UBDS Central & ( ) Sim (X) Não \\
\hline 2. Hospital São Francisco & (X) Sim ( ) Não \\
\hline 3. Hospital Beneficência Portuguesa & (X) Sim ( ) Não \\
\hline 4. Centro de Saúde Escola & ( ) Sim (X) Não \\
\hline
\end{tabular}

Fonte: elaborado pelo autor

\section{Quadro 9: Comparação entre as lixeiras dos casos de estudo}

Importante destacar que a UBDS Central não conta com nenhuma lixeira basculante com tampa e pedal nas suas dependências, enquanto que o Centro de Saúde Escola conta com algumas, em algumas salas específicas, mas a maior parte das lixeiras existentes em seus consultórios e ambulatórios ainda são as comuns. Neste sentido, a Sra. Marlene Duarte Mendes, gerente de resíduos da Secretaria Municipal da Saúde, esclareceu em entrevista que a Prefeitura Municipal está tentando adquirir o modelo de lixeira exigido pela ANVISA por meio de parcerias, bem como que para atender toda a demanda, necessitariam de cerca de quatro mil unidades deste tipo de lixeira. A Sra. Luzia Márcia R. Passos, enfermeira da vigilância epidemiológica da USP e responsável pela gerência de resíduos do Centro de Saúde Escola confirmou em parte esta informação, dizendo que só conseguiu adquirir algumas unidades de lixeira basculante com tampa e pedal há pouco tempo e que elas não são suficientes para equipar todas as unidades geradoras existentes dentro de sua organização.

O mais interessante é que a unidade privada (Hospital São Francisco) e a fundação (Hospital Beneficência Portuguesa), que contam com este tipo de equipamento (lixeira basculante com tampa e pedal) em praticamente $100 \%$ (cem por cento) de suas unidades geradoras internas, informaram em entrevista que tiveram que adquiri-las em face da fiscalização municipal, exercida pela própria Secretaria Municipal da Saúde. No caso da unidade privada, a gerente de resíduos, Sra. Sonia Maria Ferreira Marcelino Riccio, conta que inclusive o hospital teve que arranjar ou realocar recursos, de maneira extremamente rápida, "quebrando a cabeça" dos gestores da área financeira, para adquirir este equipamento, logo após uma visita da Vigilância Sanitária Municipal.

Vislumbra-se assim que, mesmo não atendendo aos termos normativos da ANVISA em suas próprias unidades (sujeitas à auto-fiscalização exercida pela própria Prefeitura Municipal), o 
poder público, por meio da Secretaria Municipal da Saúde, exige o cumprimento imediato desta mesma norma por parte dos gestores das organizações privadas.

Outro fato que também merece destaque é que a Sra. Sonia, do Hospital São Francisco, mencionou a questão das lixeiras como um caso de conflito normativo entre a ANVISA e o CONAMA, no que tange ao descarte de resíduos. Neste sentido, esclareceu em sua entrevista que a organização, antes da visita da Vigilância Sanitária Municipal que exigiu a troca de todas as suas lixeiras, possuía lixeiras coloridas, de padrão internacional (cores amarela, azul, verde e vermelha) para depósito de todo o lixo reciclado do hospital. Quando da físcalização, a Vigilância Sanitária exigiu também a troca destas lixeiras, alegando que a RDC 306/2004 da ANVISA previa o uso de equipamentos basculantes, com tampa e pedal, em praticamente todos os setores do hospital, mesmo que supostamente as resoluções 05/1993 e 283/2001 do CONAMA dispusessem de maneira contrária. Temendo então a imposição de multas ou de outras penalidades administrativas, foi providenciada a troca de todas as lixeiras da instituição, ainda que houvesse entendimento contrário seu e da direção do hospital sobre a aplicação da norma neste caso.

b) Fase de transporte interno - aspecto estudado e comparado: existência ou não de corredores exclusivos ou rotas em horários exclusivos e previamente planejadas para transporte interno de RSS, com a devida sinalização, dentro da organização. De acordo com SOUZA (2005, p. 31), o transporte interno de RSS

\footnotetext{
[...] consiste no traslado dos resíduos dos pontos de geração até local destinado ao armazenamento temporário ou armazenamento externo com a finalidade de apresentação para a coleta. O transporte interno de resíduos deve ser realizado atendendo roteiro previamente definido e em horários não coincidentes com a distribuição de roupas, alimentos e medicamentos, períodos de visita ou de maior fluxo de pessoas ou atividades. Deve ser feito separadamente de acordo com o grupo de resíduos em recipientes específicos a cada grupo de resíduos. (p. 31).
}

A RDC 306/2004 da ANVISA estabelece que o transporte interno de RSS deve ser feito num sentido único, através de roteiro previamente definido e não coincidente com a distribuição de roupas, alimentos, medicamentos, períodos de visitas e horários com fluxo maior de pessoas. Também estabelece que o transporte deve ser feito em recipientes específicos para cada grupo de resíduos, confeccionados de material rígido, lavável, impermeável e provido de tampa articulada no próprio corpo do equipamento (os recipientes com mais de 400 litros de capacidade devem ainda possuir válvula de drenagem no fundo). Por sua vez, as resoluções 5/1993 e 283/2001 do 
CONAMA determinam que o transporte interno de RSS deve ser realizado através de rotas específicas (para evitar risco de acidentes) e planejadas de modo a se percorrer a menor distância possível dentro da organização. Determinam também que sejam evitados horários e locais com grande fluxo de pessoas, bem como trafegar em corredores onde ocorram outros tipos de transporte no hospital. Determinam ainda que os RSS sejam acondicionados em recipientes que evitem manuseio e rompimento, devendo ser transportados em carros exclusivos para o transporte de cada tipo de resíduo (a CONAMA divide os RSS em quatro grupos distintos, enquanto que a ANVISA o faz em cinco categorias diferenciadas).

Feitas estas considerações, o quadro 10 apresenta uma rápida comparação entre os casos de estudo no quesito que versa sobre a existência ou não de corredores internos exclusivos para o transporte de RSS ou, ao menos, a existência de rotas exclusivas e previamente planejadas para horários de menor movimento ou locais com menor fluxo de pessoas:

\begin{tabular}{|l|l|}
\hline $\begin{array}{l}\text { Organização } \\
\text { Pesquisada }\end{array}$ & $\begin{array}{l}\text { Possui corredor interno para transporte exclusivo de RSS ou } \\
\text { rotas exclusivas e planejadas em horários ou locais com menor } \\
\text { fluxo de pessoas? }\end{array}$ \\
\hline 1. UBDS Central & ( ) Sim $\quad$ (X) Não \\
\hline 2. Hospital São Francisco & (X) Sim $\quad$ ( ) Não \\
\hline $\begin{array}{l}\text { 3. Hospital Beneficência } \\
\text { Portuguesa }\end{array}$ & (X) Sim ( ) Não \\
\hline 4. Centro de Saúde Escola & ( ) Sim (X) Não \\
\hline
\end{tabular}

Fonte: elaborado pelo autor

\section{Quadro 10: Comparativo entre os corredores dos casos do estudo}

Verificando-se a tabela, é fácil constatar que as unidades públicas estudadas não cumprem com as normas editadas pela ANVISA e pelo CONAMA, ao contrário de seus pares da iniciativa privada.

Detalhadamente, tem-se que, na UBDS Central, além de não existirem corredores exclusivos ou sinalizados para o transporte de RSS, também inexistem rotas previamente planejadas no sentido determinado pelo CONAMA e rotas que evitem horários com maior fluxo de pessoas, como disposto pelo CONAMA e pela ANVISA. Ao contrário, existem apenas horários para coleta, um pela manhã e outro logo no começo da tarde (horários estes que não são os de menor movimento na unidade), sendo certo que os carrinhos contendo lixo infectante (de 
cor branca, distintos daqueles direcionados ao lixo comum, que são de cor verde ${ }^{32}$ ) trafegam nestes horários em corredores comuns, perto ou no meio dos pacientes.

Da mesma forma, o Centro de Saúde Escola não tem corredores ou sinalização específica para o transporte de resíduos, sendo que o único procedimento diferente do que ocorre na UBDS Central fica por conta da terceirização, isto é, no prédio da chamada área programática (em que só se realizam procedimentos médicos e odontológicos previamente agendados), a limpeza e o conseqüente transporte de resíduos é feito por pessoal próprio (no caso, por empregados de sua parceira estadual, a Universidade de São Paulo), de maneira manual (os sacos plásticos de cor branca contendo resíduos infectantes são carregados manualmente pelos funcionários, que não dispõem de carros para colocá-los), passando pelas pessoas que se encontram nos corredores. Enquanto isso, no prédio de pronto atendimento, a limpeza é realizada por funcionários terceirizados, que, ao contrário dos seus colegas da área programática do Centro de Saúde Escola, contam com carros específicos para o transporte destes resíduos nos corredores do hospital, embora também se tratem de corredores comuns, em horários de fluxo normal de pessoas.

Já no Hospital São Francisco foi constatada a existência de corredores utilizados exclusivamente para transporte de RSS, no setor chamado "Hospital - Dia" (uma unidade onde o nível de ruídos é mínimo), contendo alguma sinalização específica. Também foi informado pela Sra. Josilene C. Linhares, enfermeira supervisora da empresa terceirizada "Resolv", que presta serviços de limpeza para o hospital, sobre a existência de carrinhos e recipientes exclusivos para o transporte de resíduos, de acordo com o determinado pelas normas da ANVISA. Ainda que fora do setor denominado "Hospital - Dia" estes carrinhos trafeguem carregando resíduos em corredores de uso comum, existe o planejamento prévio das rotas e horários que é rigidamente seguido pelos empregados, visando assim evitar o uso das principais vias internas e trafegar nos horários de maior movimento de pessoas. Destaque para o fato dos resíduos comuns serem coletados todos os dias, no período noturno, bem como dos resíduos reciclados serem retirados

\footnotetext{
${ }^{32}$ Existem ambos os tipos de carrinho na UBDS Central, uma vez que estes são disponibilizados pela empresa terceirizada que realiza a limpeza daquela organização (a Prefeitura não conta com carrinhos próprios para o transporte interno de RSS). A unidade é bem servida de equipamentos de proteção individual - EPI's - básicos, tais como luvas, avental, máscaras e botas, fornecidos também pela empresa terceirizada, uma vez que este tipo de material só vem do almoxarifado da Prefeitura quando não há terceirização na unidade de saúde (conforme informações colhidas na própria Secretaria Municipal da Saúde e com o pessoal operacional entrevistado).
} 
apenas nos dias úteis (segunda a sexta-feira), por volta das $17 \mathrm{~h} 00$ e dos resíduos infectantes serem retirados de segunda-feira à sábado.

Quanto à Sociedade Portuguesa de Beneficência, esta apesar de também não contar com corredores específicos para transporte de RSS, possui os equipamentos de descarte, acondicionamento e segurança, bem como recipientes para transporte, em total conformidade com as normas da ANVISA e do CONAMA, contando também com carrinhos próprios para o transporte exclusivo destes resíduos, em rotas que sempre evitam contato com carrinhos que transportam roupas ou medicamentos. Também existem horários pré-definidos para o transporte, normalmente quando o fluxo de pessoas é naturalmente menor dentro do hospital. Corredores com maior movimento procuram também ser sempre evitados.

c) Fase de tratamento - aspecto estudado e comparado: existência ou não de três dispositivos específicos para tratamento de RSS no seio das organizações, quais sejam, autoclaves (para esterilização a vapor), microondas e tochas de plasma ${ }^{33}$.

É certo que existe legislação (seja em caráter lato ou stricto) que determina que alguns tipos de resíduos gerados dentro de organizações de saúde, sejam por suas características físicoquímicas próprias ou pelo próprio grau de risco que representem ao meio ambiente e à saúde pública, sejam tratados dentro da própria instituição, antes de seu descarte final para aterros, valas sanitárias, etc. Neste sentido, pode-se mencionar o próprio artigo 23, inciso VI da Constituição Federal, o qual fixa a competência comum da União, dos Estados, do Distrito Federal e dos Municípios no que se refere à proteção do meio ambiente nacional e no combate à poluição em qualquer uma de suas formas, sólida, líquida ou gasosa.

\footnotetext{
Vale observar que o legislador optou por conceituar poluição considerando o resultado de uma atividade (que prejudique a saúde, a segurança, afete a biota, etc.) e, em alguns casos, definindo a própria conduta (lançar matéria ou energia em desacordo com os padrões ambientais estabelecidos), de tal forma que, ocorrendo alguma das hipóteses elencadas, deverá o seu causador indenizar o dano. (FIORILLO, 2008, p. 42).
}

Dentre os RSS que devem receber tratamento dentro da própria organização geradora, o CONAMA, através da resolução 5/1993 e, posteriormente, resolução 283/2001, menciona os

\footnotetext{
33 “Esterilização por Plasma. Já utilizado na Alemanha e no Japão. Apresenta um alto custo de instalação e operação. Gaseifica e vitrifica todos os resíduos através de tochas ou cilindros térmicos com potência entre 50 a $500 \mathrm{KW}$, a $1600^{\circ} \mathrm{C}$ (...). O plasma gasoso é chamado de $4^{\circ}$ estado da matéria, sendo uma espécie de gás ionizado. Não libera gases poluentes para a atmosfera, reduz amplamente o volume dos resíduos e sua manipulação é automática".(SOUZA, 2005, p. 41).
} 
pertencentes ao Grupo A de sua classificação (resíduos com risco biológico), com o objetivo de diminuir os agentes patológicos presentes nos mesmos (as formas de tratamento para este tipo de resíduo são: autoclave, microondas, tratamento químico, radiação ionizante e incineração por pirólise ou plasma). Da mesma forma, a ANVISA, por meio da RDC 33/03, também considera passíveis de tratamento os resíduos classificados em seu Grupo A, denominados "potencialmente infectantes" (ressalte-se mais uma vez que o CONAMA classifica os RSS em quatro grupos distintos, enquanto que a ANVISA o faz em cinco grupos).

Quanto às formas ou modos de tratamento propriamente ditos, Takanayagui, na obra organizada por Philippi Jr. (2005) já esclareceu existirem várias delas, como desinfecção química, inativação térmica, incineração, esterilização a vapor (por meio de autoclaves), microondas, etc. A análise efetuada procurou observar, como já exposto, a presença e o uso de 3 (três) destes dispositivos pelos casos de estudo - autoclaves, microondas e tocha de plasma dispostos conforme o quadro 11 .

\begin{tabular}{|c|c|c|c|}
\hline \multirow{2}{*}{$\begin{array}{l}\text { Organização } \\
\text { Pesquisada }\end{array}$} & \multicolumn{3}{|c|}{ Presença de Dispositivos para Tratamento Interno de RSS } \\
\hline & Autoclave & Microondas & Tocha de Plasma \\
\hline 1. UBDS Central & ( ) Sim (X) Não & ( ) Sim (X) Não & ( ) $\operatorname{Sim}(X)$ Não \\
\hline $\begin{array}{ll}\text { 2. Hospital São } \\
\text { Francisco }\end{array}$ & (X) Sim ( ) Não & (X) Sim ( ) Não & ( ) $\operatorname{Sim}(X)$ Não \\
\hline $\begin{array}{l}\text { 3. Hospital Beneficência } \\
\text { Portuguesa }\end{array}$ & (X) Sim ( ) Não & (X) Sim ( ) Não & ( ) Sim (X) Não \\
\hline $\begin{array}{l}\text { 4. Centro de Saúde } \\
\text { Escola }\end{array}$ & ( ) Sim (X) Não & ( ) Sim (X) Não & ( ) Sim (X) Não \\
\hline
\end{tabular}

Fonte: elaborado pelo autor

\section{Quadro 11: Comparativo do tratamento interno de resíduos dos casos do estudo}

Vislumbrando-se a tabela, observa-se que ambas as unidades públicas, UBDS Central e Centro de Saúde Escola, não possuem em suas instalações nenhum dos dispositivos para tratamento de resíduos retro mencionados, sendo certo que os dois primeiros são considerados aparelhos básicos de esterilização e o último um aparelho sofisticado (existindo poucos hospitais que dispõem do mesmo no Brasil).

As entrevistas realizadas com as responsáveis de ambas as organizações convergem com as informações fornecidas pela gerente de resíduos da Secretaria da Saúde Municipal, no sentido de que a Prefeitura só dispõe de uma única máquina de autoclave para esterilização dos resíduos gerados por todas as unidades da rede e de que esta, curiosamente, não fica no Posto de Saúde 
Central, mas sim na UBDS responsável pela zona leste da cidade, qual seja, do bairro Castelo Branco (UBDS Dr. Ítalo Baruffi).

Quanto ao microondas, a Prefeitura Municipal sequer o possui, sendo certo que quando se faz necessário seu uso, quem dispõe do mesmo é a empresa terceirizada que faz a coleta de resíduos para a Secretaria Municipal da Saúde.

Como ocorreu com outros fatores já comparados, a situação do hospital privado e da fundação é totalmente diversa da de seus pares no poder público, uma vez que ambos (Hospital São Francisco e Beneficência Portuguesa) contam em suas unidades com aparelhos de autoclave e microondas. A ausência constatada de tocha de plasma em ambos, não demonstra que estas organizações não estejam preparadas para tratar todos os resíduos gerados por suas atividades (uma vez que este último dispositivo, além de ser muito caro, é pouco utilizado no Brasil), pelo contrário, uma vez que os dois primeiros aparelhos (autoclave e microondas) são utilizados para esterilização da maior parte dos RSS produzidos em qualquer instituição de saúde.

d) Fase de armazenamento externo - aspecto estudado e comparado: existência e condições físicas dos abrigos externos dos casos de estudo. Antes de se formular as primeiras arguições sobre o que fora constatado com relação aos abrigos, mister ressaltar o ensinamento de SOUZA (2005), quanto ao armazenamento externo, no sentido de que ele

[...] consiste na guarda dos recipientes de resíduos até a realização da etapa de coleta externa, em ambiente exclusivo com acesso facilitado para os veículos coletores. No armazenamento externo não é permitida a manutenção dos sacos de resíduos fora dos recipientes ali estacionados. (p. 33/34).

A ANVISA, através da RDC 33/2003, diz que o piso dos abrigos externos deve ser revestido de material liso, impermeável, lavável de fácil higienização, assim como as paredes, devendo ainda ter telas de proteção contra a entrada de insetos e roedores. Já o CONAMA, por meio das resoluções 5/1993 e 283/2001, estabelece que os abrigos estejam em área delimitadamente separada do estabelecimento de saúde (para evitar contaminações), bem como que a construção de aludido depósito deve seguir estritamente o disposto na NBR 12810 da ABNT e também as normas do Ministério da Saúde aplicáveis ao caso.

Dito isto, o quadro 12 apresenta comparação entre o estado de conservação dos abrigos externos de RSS e sua adequação ou não com o preconizado pelas resoluções da ANVISA e do CONAMA: 


\begin{tabular}{|l|l|}
\hline Organização Pesquisada & $\begin{array}{l}\text { Existe abrigo externo e, em caso positivo, este se encontra em } \\
\text { conformidade com a RDC 33/03 (ANVISA) e resoluções 5/93 e } \\
\mathbf{2 8 3 / 0 1} \text { (CONAMA)? }\end{array}$ \\
\hline 1. UBDS Central & (X) Sim ( ) Não \\
\hline 2. Hospital São Francisco & (X) Sim ( ) Não \\
\hline 3. Hospital Beneficência Portuguesa & ( ) $\operatorname{Sim}$ (X) Não \\
\hline 4. Centro de Saúde Escola & ( ) Sim (X) Não \\
\hline
\end{tabular}

Fonte: elaborado pelo autor

\section{Quadro 12: Comparativo entre os abrigos externos dos casos do estudo}

Comparando as situações constatadas, verificou-se que, desta vez, ao menos uma das unidades públicas (a UBDS Central) saiu na frente de uma das unidades privadas (a Beneficência Portuguesa), uma vez que, na primeira, quando realizadas as entrevistas com o pessoal operacional, foi mencionada a existência de uma "casinha" para depósito externo do lixo infectante, sobre a qual, após visita, constatou-se a existência de piso, revestimento, grade de proteção e razoável estado de conservação e limpeza.

Desta mesma forma, encontrava-se o depósito externo para RSS do Hospital São Francisco, atendendo assim, numa primeira análise, as normas da ANVISA e CONAMA. Apesar disso, a gestora Sonia Maria Ferreira Marcelino Riccio disse em entrevista que é muito difícil atender a legislação no que tange ao armazenamento dos resíduos químicos, uma vez que a região não possui aterro adequado para este tipo de resíduo e, por este motivo, a coleta externa só é realizada a cada quinze dias, com destino final para o aterro situado na cidade de Paulínia - SP.

Já os abrigos para depósito provisório externo de RSS do Hospital Beneficência Portuguesa e do Centro de Saúde Escola, apesar de separados fisicamente das instalações destas organizações, não continham revestimento, piso e porta telada, consistindo-se mais em "casinhas" para armazenamento de lixo, ou seja, estavam em total desacordo com as normas da ANVISA, CONAMA e com os procedimentos previstos pela ABNT e Ministério da Saúde.

Por fim, mais não menos importante do que a análise sobre a infra-estrutura de cada entidade, é também se analisar como se dá o fluxo de informações entre os gestores dos casos de estudo $^{34}$ e os demais funcionários, no que tange ao manejo diário dos resíduos, ou seja, averiguar como funciona o canal de comunicação entre a direção ou gerência e o pessoal de nível

\footnotetext{
${ }^{34}$ Com exceção do Hospital Sociedade Portuguesa de Beneficência, em que não foi possível fazer esta análise, porque não houve resposta concreta neste sentido por parte do funcionário de nível operacional entrevistado e nem pelo responsável pelo setor de resíduos.
} 
operacional no que tange aos procedimentos e processos da organização envolvendo o gerenciamento de resíduos.

Neste sentido, saliente-se que, na UBDS Central, segundo informações colhidas do pessoal operacional, tudo o que diga respeito a métodos e procedimentos envolvendo resíduos lhes é repassado diretamente pela Sra. Marlene Duarte Mendes, da Secretaria Municipal da Saúde, não havendo qualquer comunicação direta com a gerência local sobre assuntos envolvendo resíduos. Estas informações corroboram o que disse a própria gerente geral da unidade, no sentido de que todas as matérias e determinações envolvendo resíduos provêm da Secretaria Municipal da Saúde (o que remete novamente à questão da prática de mero gerenciamento de RSS na unidade).

Já no Hospital São Francisco, o canal de comunicação entre a gestora e os funcionários funciona de uma maneira mais simples e direta, sem necessidade de se suplantar grau hierárquico na entidade (como ocorre no Posto de Saúde Central), existindo um empregado específico que faz esta ponte: o enfermeiro do projeto (interno da organização) chamado de "Educação Continuada".

Finalmente, no Centro de Saúde Escola, as respostas do pessoal de nível operacional entrevistado (inclusive terceirizado) foram exatamente as mesmas da UBDS Central, qual seja, de que tudo o que diz respeito à procedimentos envolvendo os RSS lhes é passado diretamente pela Sra. Marlene, da Secretaria da Saúde Municipal, não havendo ingerência, interferência ou mesmo participação da gerência local ou de qualquer outro chefe ou funcionário da própria unidade, no que tange à assuntos envolvendo este tema.

\subsection{O Conhecimento Normativo e a Capacitação do Pessoal}

Muitos dos dados coletados na pesquisa apontaram qual seria o nível de conhecimento jurídico que os gestores, gerentes e demais responsáveis pela área de resíduos de serviços de saúde nos casos do estudo teria, bem como o quanto estes mesmos administradores estariam atualizados no que diz respeito aos procedimentos envolvendo RSS dentro de suas organizações.

Neste sentido, o quadro 13 foi formulado trazendo as principais informações coletadas, nas quatro organizações estudadas, a este respeito (cujo tema é essencial para se responder algumas das questões fundamentais a que a presente pesquisa se propôs). 


\begin{tabular}{|c|c|}
\hline \multicolumn{2}{|c|}{$\begin{array}{c}\text { CONHECIMENTO JURÍDICO - NORMATIVO (SOBRE RSS) E GRAU DE ATUALIZAÇÃO } \\
\text { DEMONSTRADO PELOS GERENTES }\end{array}$} \\
\hline \multirow{3}{*}{$\begin{array}{l}\text { 1. } \mathrm{Na} \text { UBDS } \\
\text { Central }\end{array}$} & Cargo da entrevistada: gerente geral da unidade \\
\hline & $\begin{array}{l}\text { Esclareceu que todos os procedimentos envolvendo resíduos que chegam à sua mão passam } \\
\text { antes pela Secretaria Municipal da Saúde. Soube dizer apenas que a Prefeitura Municipal } \\
\text { segue a cartilha da ANVISA. Não soube enumerar qualquer dispositivo do CONAMA, } \\
\text { CETESB/SP ou da legislação federal, estadual e municipal envolvendo resíduos, uma vez que } \\
\text { tudo o que envolve o tema já vem com orientações prévias do que é ou não é para fazer. Por } \\
\text { não tomar decisões envolvendo RSS, afirmou nunca ter se deparado com procedimentos } \\
\text { conflitantes em leis ou normas. O único documento escrito que tem acesso é o Diário Oficial } \\
\text { do Município e, apesar de contar com Internet em sua sala, diz não acessar os sites do } \\
\text { Ministério da Saúde, ABNT, CONAMA e outros. Não se considera atualizada sobre leis e } \\
\text { normas envolvendo RSS, mas disse que, caso tenha alguma dúvida sobre algum procedimento, } \\
\text { tem um canal de comunicação direto com a Secretaria Municipal da Saúde. }\end{array}$ \\
\hline & Possui departamento jurídico próprio? ( ) Sim (X) Não \\
\hline \multirow{3}{*}{$\begin{array}{l}\text { 2. No Hospital } \\
\text { São Francisco }\end{array}$} & $\begin{array}{l}\text { Cargo da entrevistada: gerente de enfermagem (pertencendo também à Comissão e } \\
\text { Gerenciamento de Resíduos do hospital) }\end{array}$ \\
\hline & $\begin{array}{l}\text { Mostrou-se razoavelmente atualizada com a legislação ambiental atualmente em vigor, bem } \\
\text { como com relação aos principais dispositivos da ANVISA e do CONAMA relativos à RSS. } \\
\text { Fez também alguma menção à ABNT. Esclareceu que sofre fiscalização eventual de todos } \\
\text { estes órgãos (não mais de uma vez por ano de cada um), bem como e também eventualmente } \\
\text { do Governo Federal (Ministérios da Saúde e do Meio Ambiente), apesar da fiscalização mais } \\
\text { ostensiva ser da própria Secretaria da Saúde Municipal, por meio da Vigilância Sanitária. Por } \\
\text { este motivo, alegou que, dentre todas as normas, a mais aplicada (e conhecida) no hospital } \\
\text { também é a RDC } 306 / 2004 \text { da ANVISA. Não obstante, participa sempre de cursos, palestras e } \\
\text { jornadas, dentro e fora do hospital (no mínimo a cada ano). Acessa eventualmente o Diário } \\
\text { Oficial da União, do Estado e do Município por meio da diretoria geral. Acessa } \\
\text { ocasionalmente os sites da Prefeitura Municipal, Governo Estadual, Ministérios Federais, bem } \\
\text { como da ANVISA e do CONAMA. Diz que estes sites também são acessados por toda a } \\
\text { Comissão de Gerenciamento de Resíduos do hospital (composta pelo SESMT, laboratórios e } \\
\text { CCIH). Informou também que o hospital conta com um departamento jurídico especializado, } \\
\text { que acompanha, junto com ela, toda a parte normativa envolvendo RSS, desde sua geração } \\
\text { pelos mais diversos setores do hospital, até sua destinação final. Considera-se (e também se } \\
\text { mostrou) atualizada sobre tudo o que diz respeito a RSS, já tendo vivenciado situações } \\
\text { conflitantes envolvendo as lixeiras do hospital, existindo neste caso normas e procedimentos } \\
\text { distintos do CONAMA e da Vigilância Sanitária da Secretaria da Saúde Municipal (que segue } \\
\text { a ANVISA), a qual acabou prevalecendo após deliberação geral do Comitê de Gerenciamento } \\
\text { de Resíduos. }\end{array}$ \\
\hline & Possui departamento jurídico próprio? (X) Sim ( ) Não \\
\hline \multirow{2}{*}{$\begin{array}{l}\text { 3. No Hospital } \\
\text { Beneficência } \\
\text { Portuguesa }\end{array}$} & $\begin{array}{l}\text { Cargo do entrevistado: técnico em segurança do trabalho (cumulando com as funções de chefe } \\
\text { do setor de resíduos) }\end{array}$ \\
\hline & $\begin{array}{l}\text { Demonstrou ter grande conhecimento e estar atualizado sobre os principais dispositivos da } \\
\text { ANVISA, CONAMA e CETESB/SP envolvendo RSS (mencionou várias destas normas na } \\
\text { entrevista, inclusive procedimentos conflitantes entre a ANVISA e a CONAMA com que já se } \\
\text { deparou na prática). Também acompanha cotidianamente o Diário Oficial da União, } \\
\text { notadamente as publicações do Ministério da Saúde e do Meio Ambiente, bem como de tudo o } \\
\text { que diga respeito à temas ligados à organizações prestadoras de serviços de saúde e RSS. } \\
\text { Também acompanha ocasionalmente o Diário Oficial do Município. Esclareceu que a direção } \\
\text { geral do hospital procura sempre manter todos os funcionários atualizados em qualquer tema } \\
\text { envolvendo saúde pública e meio ambiente, dando como exemplo o curso "Plano de } \\
\text { Gerenciamento de RSS", que fora ministrado em abril/2008 pelo hospital, para todos os } \\
\text { funcionários que se interessassem e profissionais da saúde da região, na organização } \\
\text { denominada "Pró-Saúde". Disse, por fim, que participou da elaboração do PGRSS do } \\
\text { hospital, ocasião em que constatou conflitos entre os órgãos que editam normas sobre RSS, os }\end{array}$ \\
\hline
\end{tabular}




\begin{tabular}{|c|c|}
\hline & $\begin{array}{l}\text { quais procuraram ser solucionados através da adoção da legislação que fosse mais viável } \\
\text { operacionalmente. Disse ser favorável à junção de todas as leis (inclusive estaduais e } \\
\text { municipais) e normas, num único corpo normativo. }\end{array}$ \\
\hline & Possui departamento jurídico próprio? (X) Sim ( ) Não \\
\hline \multirow{3}{*}{$\begin{array}{lr}\text { 4. No Centro } \\
\text { de } & \text { Saúde } \\
\text { Escola } & \text { da } \\
\text { Faculdade de } \\
\text { Medicina de } \\
\text { Ribeirão Preto }\end{array}$} & Cargo da entrevistada: enfermeira da vigilância epidemiológica \\
\hline & $\begin{array}{l}\text { O primeiro esclarecimento prestado pela entrevistada foi que a unidade não possui um } \\
\text { departamento específico de resíduos, cabendo a gerência à ela, em conjunto com a chefia } \\
\text { administrativa. Da mesma forma que a gerente geral da UBDS Central, esclareceu que todas } \\
\text { as decisões sobre RSS se centralizam na Secretaria Municipal da Saúde, cabendo a ela aplicar } \\
\text { os procedimentos que lhe são passados. Não acompanha nenhum Diário Oficial (da União, do } \\
\text { Estado ou do Município) e informou que os únicos documentos impressos que tem acesso são } \\
\text { os remetidos pela Secretaria Municipal da Saúde, através de protocolos circulares. Informou } \\
\text { também que até acessa ocasionalmente sites de variados órgãos ligados à saúde e ao meio } \\
\text { ambiente, mas que todos os procedimentos que adota são aqueles determinados pela Prefeitura } \\
\text { Municipal. Informou ainda que tem consciência que podem haver discrepâncias entre leis e } \\
\text { normas editadas pelos mais variados órgãos ambientais, mas entende que a parte jurídica é } \\
\text { muita técnica e que não cabe a ela ter qualquer conhecimento técnico sobre esse assunto. Não } \\
\text { soube apontar divergências normativas, mas disse que é muito difícil seguir estritamente o que } \\
\text { diz a RDC } 306 \text { da ANVISA em suas atividades cotidianas de gerenciamento de RSS. Também } \\
\text { Já se deparou com procedimentos inviáveis operacionalmente, como a questão dos abrigos } \\
\text { provisórios para o lixo (emendando depois que esta questão já estaria hoje resolvida pela } \\
\text { Prefeitura). Por fim, apontou que a maior dificuldade para cumprir a legislação sobre RSS é a } \\
\text { educação, citando como exemplo: médicos e alunos que descartam agulhas em recipientes } \\
\text { incorretos (entende que a educação, orientação e conscientização deve abranger todas as } \\
\text { pessoas da rede municipal da saúde, inclusive usuários. Também se disse favorável à } \\
\text { compilação de todas as leis e normas existentes em um único código. }\end{array}$ \\
\hline & Possui departamento jurídico próprio? ( ) Sim (X) Não \\
\hline
\end{tabular}

Fonte: elaborado pelo autor

\section{Quadro 13: Comparativo entre o conhecimento jurídicos dos gestores}

O que se pode concluir dos dados compilados na tabela retro não difere de tudo o que já restou exposto até aqui no presente trabalho. Desta forma, na UBDS Central, a gerente geral da unidade não demonstrou grande conhecimento sobre leis e normas que envolvem RSS, o que se explica, em parte, pelo fato de todas as decisões envolvendo resíduos partirem da gerente de resíduos da Secretaria Municipal da Saúde, Sra. Marlene Duarte Mendes. Já no Hospital São Francisco, a gerente de resíduos se mostrou mais atualizada e conhecedora das normas envolvendo resíduos, independentemente da organização contar com um departamento jurídico próprio, o que confirma as informações prestadas de que todas as decisões envolvendo RSS, bem como sua gestão, é praticada por meio de reuniões envolvendo vários setores do hospital (conforme será melhor elucidado no tópico posterior). De maneira parecida, no Hospital Beneficência Portuguesa, o responsável pelo gerenciamento dos RSS se mostrou atualizado e 
conhecedor das principais leis e normas envolvendo resíduos (provindas estas últimas de variados órgãos), confirmando assim a preocupação da organização com questões ambientais e demonstrando porque a mesma foi pioneira, na cidade, na implementação de um PGRSS. Por fim, no Centro de Saúde Escola, apesar da gerente de RSS se mostrar um pouco mais atualizada e conhecedora do tema do que a gerente geral do Posto de Saúde Central, seus conhecimentos não se comparam com aqueles demonstrados pelas duas instituições privadas, o que também se explica pelo fato das decisões envolvendo resíduos, como na UBDS Central, virem prontas e previamente determinadas pela Secretaria Municipal de Saúde.

Sobre o conhecimento demonstrado pelos gestores e sua contribuição para o próprio funcionamento e desenvolvimento da organização (de modo que a mesma atue sem descumprir as normas vigentes), cabe transcrever o pensamento sempre atual de Rivera (2003):

\begin{abstract}
A subjetividade na gestão é um tema que está na ordem do dia em função da relativa crise da gestão procedimental e da emergência de uma nova visão que destaca a importância da cultura (na formulação dos objetivos organizacionais), da liderança comunicativa e da aprendizagem organizacional. A organização passa a ser concebida como uma sociedade que aprende a aprender. (...). A aprendizagem, para os teóricos da learning organization, deve ser vista como um processo contínuo com as seguintes etapas: aprender a perceber ou a reinterpretar uma situação, aprender como aplicar esta percepção para a formulação de uma política e especificação de uma ação, aprender como implementar estas políticas e ações pretendidas, e aprender como manter estes três últimos itens ativos, vivos, e abertos à constante revisão. (p. 245-246).
\end{abstract}

De todo modo, uma vez analisado o conhecimento jurídico e normativo dos gestores no que diz respeito à gerência de RSS, cabe analisar, também, do nível de capacitação e de treinamento do pessoal subordinado aos mesmos, que trabalha com resíduos no cotidiano destas organizações, seja coletando, descartando, limpando, transportando ou os encaminhando para sua destinação final.

Nesse sentido, cabe observar as informações contidas no quadro 14, onde se procurou compilar os principais dados coletados nas entrevistas realizadas:

NÍVEL DE CAPACITAÇÃO E DE TREINAMENTO DO PESSOAL QUE TRABALHA COM RSS

\begin{tabular}{|l|l|}
\hline & \begin{tabular}{l} 
1. Quantidade de entrevistados (pessoal de nível operacional): ( ) 1 (X) 2 ( ) 3 ( ) 4 ( ) 5 \\
\cline { 2 - 3 } $\begin{array}{l}\text { 1. Na Nomes e cargos: Elsa Muralha de Souza - Auxiliar de Serviço (terceirizada) } \\
\text { Valquíria Cristina Flores - Auxiliar de Limpeza (terceirizada) }\end{array}$
\end{tabular} \\
\cline { 2 - 3 } Central & $\begin{array}{l}\text { 2. TBDS } \\
\text { 3. Todas tiveram treinamentos ou cursos sobre RSS? (X) Sim ( ) Não }\end{array}$ \\
\cline { 2 - 3 } & $\begin{array}{l}\text { 4. Em caso positivo à pergunta anterior, quem ministrou? } \\
\text { (X) A própria organização para quem trabalha(m) } \\
\text { (X) A(s) empresa(s) terceirizada(s) a(s) qual(is) está(ão) vinculado(s) } \\
\text { ( ) Outros }\end{array}$ \\
\hline
\end{tabular}




\begin{tabular}{|c|c|}
\hline & $\begin{array}{l}\text { 5. Observações: a Sra. Elsa Muralha, funcionária da empresa "Guima" há mais de oito anos } \\
\text { (todos eles trabalhando em unidades de saúde da Prefeitura Municipal), esclareceu que já } \\
\text { participou de sete cursos de capacitação e treinamento para separação, coleta e descarte de } \\
\text { RSS, sendo um deles ministrado pela Prefeitura Municipal, dois pela Secretaria Municipal da } \\
\text { Saúde e quatro pela sua própria empregadora (terceirizada). Já a Sra. Valquíria reporta ter feito } \\
\text { um único curso (na verdade um treinamento profissional), na empresa "Guima", quando de } \\
\text { sua admissão. }\end{array}$ \\
\hline \multirow{5}{*}{$\begin{array}{l}\text { 2. No Hospital } \\
\text { São Francisco }\end{array}$} & 1. Quantidade de entrevistados (pessoal de nível operacional): ( ) 1 (X) 2 ( ) 3 ( ) 4 ( ) 5 \\
\hline & $\begin{array}{l}\text { 2. Nomes e cargos: Josilene C. Linhares - Enfermeira Supervisora (terceirizada) } \\
\text { Neide M. O. Souza - Coordenadora Geral de Enfermagem }\end{array}$ \\
\hline & 3. Todos tiveram treinamentos ou cursos sobre RSS? (X) Sim ( ) Não \\
\hline & $\begin{array}{l}\text { 4. Em caso positivo à pergunta anterior, quem ministrou? } \\
\text { (X) A própria organização para quem trabalha(m) } \\
\text { ( ) A(s) empresa(s) terceirizada(s) a(s) qual(is) está(ão) vinculado(s) } \\
\text { ( ) Outros }\end{array}$ \\
\hline & $\begin{array}{l}\text { 5. Observações: tanto a Sra. Josilene (que trabalha na empresa terceirizada "Resolv"), quanto a } \\
\text { Sra. Neide, funcionária do hospital, informaram terem participado de uma série de cursos, } \\
\text { treinamentos, jornadas e palestras envolvendo resíduos, todas promovidas pela própria direção } \\
\text { do hospital ou patrocinadas pelo mesmo. Um exemplo dos eventos citados foi o } \\
\text { "SOBRAGEM", realizado em 2008, na cidade de Campos do Jordão - SP. }\end{array}$ \\
\hline \multirow{5}{*}{$\begin{array}{l}\text { 3. No Hospital } \\
\text { Beneficência } \\
\text { Portuguesa }\end{array}$} & 1. Quantidade de entrevistados (pessoal de nível operacional): (X) 1 ( ) 2 ( ) 3 ( ) 4 ( ) 5 \\
\hline & $\begin{array}{l}\text { 2. Nomes e cargos: (não autorizou a divulgação de seu nome) - Auxiliar de Segurança no } \\
\text { Trabalho }\end{array}$ \\
\hline & 3. Todos tiveram treinamentos ou cursos sobre RSS? (X) Sim ( ) Não \\
\hline & $\begin{array}{l}\text { 4. Em caso positivo à pergunta anterior, quem ministrou? } \\
\text { ( ) A própria organização para quem trabalha(m) } \\
\text { ( ) A(s) empresa(s) terceirizada(s) a(s) qual(is) está(ão) vinculado(s) } \\
\text { (X) Outros }\end{array}$ \\
\hline & $\begin{array}{l}\text { 5. Observações: o funcionário informou ter participado de um curso promovido pela Prefeitura } \\
\text { Municipal de Ribeirão Preto, há cerca de } 4 \text { (quatro) anos, bem como que participaria, ainda em } \\
\text { 2008, de outro curso, que seria promovido pela empresa "Ambicamp", que presta serviços } \\
\text { para o hospital, efetuando a coleta dos resíduos químicos gerados pela instituição. }\end{array}$ \\
\hline \multirow{5}{*}{$\begin{array}{ll}\text { 4. No Centro de } \\
\text { Saúde Escola } & \text { da } \\
\text { Faculdade } & \text { de } \\
\text { Medicina } & \text { de } \\
\text { Ribeirão Preto } & \end{array}$} & 1. Quantidade de entrevistados (pessoal de nível operacional): ( ) 1 (X) 2 ( ) 3 ( ) 4 ( ) 5 \\
\hline & $\begin{array}{l}\text { 2. Nomes e cargos: Renilda Bernardes - Auxiliar de Serviços } \\
\text { Silvia A. de Campos Correa Rocha - Auxiliar de Limpeza (terceirizada) }\end{array}$ \\
\hline & 3. Todos tiveram treinamentos ou cursos sobre RSS? ( ) Sim (X) Não \\
\hline & $\begin{array}{l}\text { 4. Em caso positivo à pergunta anterior, quem ministrou? } \\
\text { ( ) A própria organização para quem trabalha(m) } \\
\text { ( ) A(s) empresa(s) terceirizada(s) a(s) qual(is) está(ão) vinculado(s) } \\
\text { (X) Outros }\end{array}$ \\
\hline & $\begin{array}{l}\text { 5. Observações: a Sra. Renilda, que é funcionária da USP (uma das parceiras do Centro de } \\
\text { Saúde Escola ou UBDS Joel Domingos Machado), informou que a unidade não promove } \\
\text { cursos e nem treinamentos, mas a USP sim. Chegou a freqüentar um ou dois cursos sobre RSS } \\
\text { na USP e disse que, quando a Secretaria Municipal da Saúde também ministra alguma coisa, } \\
\text { as funcionárias da limpeza são convidadas a participar. Já a Sra. Silvia foi o caso único dentre } \\
\text { todas as pessoas entrevistadas, em todas as organizações estudadas, que disse que jamais } \\
\text { recebeu qualquer curso ou treinamento sobre RSS, à exceção dos procedimentos que lhe foram } \\
\text { passados pela empresa "Única Limpadora", para a qual trabalha há } 5 \text { (cinco) anos, na época de } \\
\text { sua contratação. }\end{array}$ \\
\hline
\end{tabular}

Fonte: elaborado pelo autor

Quadro 14: Comparativo da capacitação do pessoal nos casos do estudo 
Sobre a capacitação do pessoal que trabalha na parte operacional envolvendo resíduos de serviços de saúde (por exemplo, no descarte, na coleta e no transporte internos), é de se perceber que, com exceção do Hospital Beneficência Portuguesa (que possui pessoal de limpeza próprio, apesar de não entrevistado diretamente), todas as outras organizações estudadas possuem funcionários de empresas terceirizadas 35 ("Guima", "Resolv" e "Única Limpadora”) para a execução deste tipo de serviço, ainda que parcialmente (como o caso do Centro de Saúde Escola, que possui parte do quadro da limpeza terceirizado e parte composto de pessoal próprio - da USP).

Com relação à terceirização deste pessoal, frise-se que não existe nada em toda a legislação ambiental federal, estadual ou municipal levantada, bem como nas normas da ANVISA, CONAMA, ABNT e outros, que proíba organizações prestadoras de serviços de saúde de contratar empresas terceirizadas para efetuar serviços de descarte, limpeza, coleta e transporte interno de RSS. Deste modo, não se vislumbra que nenhuma destas organizações atue de maneira irregular neste aspecto.

Por outro lado, a realização de cursos e treinamentos que visem a capacitação dos funcionários, que, sem grandes diferenças de freqüência, foi constatada em todas as organizações estudadas, de um modo geral, alcançam também todos os envolvidos com RSS, dos gerentes ao menos graduado funcionário da limpeza, bem como de empregados próprios a colaboradores pertencentes a empresas terceirizadas. Neste sentido:

\footnotetext{
Nenhum sistema é melhor do que as pessoas que vão operacioná-lo. Essa é a primeira lição que o gestor deve aprender e praticar. É preciso que a valorização das pessoas seja uma prática constante e efetiva. Não basta elogiar as pessoas ou chamá-las de recursos especiais, pois slogans e demagogias são práticas ultrapassadas. É preciso tratar as pessoas como pessoas e não mais como material, bens depreciáveis e recursos, tal qual instalações, equipamentos, salas, portas, títulos, ações, máquina, computador, etc. Talvez, por serem material especial e recursos especiais, dispensamos às pessoas atenção e cuidados especiais para que a meta da produção de bens e serviço seja alcançada. Nunca, porém, deixam de ser material ou recursos. E, sendo material ou recursos, só eventualmente serão consideradas pessoas com aspirações e objetivos. (...).

Levando estas reflexões ao ambiente hospitalar, onde a qualidade dos serviços médicohospitalares depende efetivamente das pessoas - empregados administrativos, enfermeiros e médicos - , perceberemos quão importante é a valorização das pessoas como pessoas para a consecução dos objetivos organizacionais. (TARABOULSI, 2004, p. 39).
}

\footnotetext{
${ }^{35}$ De acordo com a Sra. Marlene Duarte Mendes, da Secretaria Municipal da Saúde, das cinqüenta e oito unidades que compõem a rede pública de saúde municipal, quinze tem o serviço de limpeza terceirizado. Também de acordo com ela, os editais da Prefeitura Municipal para contratação de empresas terceirizadas para execução da limpeza nos postos de saúde, exigem sempre que as mesmas tenham pessoal treinado em manejo de RSS.
} 
Neste prisma, ressalte-se que também não foram encontradas diferenças significativas entre os casos do estudo, no que tange às informações colhidas nas entrevistas realizadas com o pessoal de nível operacional, relativamente ao conhecimento demonstrado pelos mesmos, bem como se considerando o seu nível de capacitação e de treinamento; sendo constatado que todas as organizações, de maneira direta ou indireta (através das empresas terceirizadas), promovem cursos ou treinamentos sobre RSS, bem como incentivam seu pessoal a freqüentá-los. A única exceção ficou por conta de uma das funcionárias entrevistadas no Centro de Saúde Escola, que apesar de dizer que nunca freqüentou um curso específico sobre RSS, ao menos recebeu treinamento básico da própria empresa terceirizada que a contratou, antes de iniciar suas atividades dentro da aludida instituição de saúde (afinal, a informação dada pela funcionária não pressupõe que a mesma não possa, num futuro próximo, freqüentar algum curso neste sentido, notadamente porque a outra entrevistada disse que tanto a USP quanto a Secretaria Municipal da Saúde promovem ocasionalmente este tipo de cursos e é facultado aos funcionários daquela unidade participarem dos mesmos).

Feitas estas considerações, torna-se até mesmo desnecessário fazer um parêntesis para destacar a grande importância das organizações investirem em capacitação e treinamento, sendo também desnecessário frisar que, na área da saúde, é extremamente importante que os empregados conheçam não só as normas que regulamentam suas funções, mas também os procedimentos que determinam a aplicação destas normas no seu cotidiano de trabalho, sendo inquestionável que qualquer descuido, como, por exemplo, um descarte errado ou um resíduo enviado à destinação final sem tratamento, poderão acarretar danos irreparáveis à saúde pública e ao meio ambiente.

\subsection{A Autonomia na Tomada de Decisões}

A última análise que cabe ser feita quanto aos dados colhidos nas organizações estudadas se refere ao modo como são tomadas as decisões envolvendo o gerenciamento RSS. Neste aspecto, estudar a autonomia de cada gestor para tomar decisões (e, por conseqüência, traçar rumos ou implantar novos procedimentos na organização), é muito importante para ajudar a solucionar alguns dos questionamentos básicos que a presente pesquisa buscou responder, 
notadamente com relação a eventuais conflitos normativos que o mesmo já teve ou ainda pode ter que enfrentar.

Para Hampton (2005):

A versão idealizada da organização integrada, lógica e à busca da realização de objetivos e a imagem ideal dos tomadores de decisão racionais, com suas receitas contendo as seqüências de todos os passos a serem seguidos, são uma ficção útil, assim como as figuras literárias heróicas. (2005, p. 230).

Referido autor teceu estas considerações com o objetivo de esclarecer que o processo de tomada de decisões dentro de qualquer organização não é uma ciência exata, consistente simplesmente de etapas pré-definidas e sequenciais (definição do problema, obtenção de todos os fatos envolvidos, formulação de alternativas e decisão por uma destas), mas sim um processo complexo, que deve levar em conta todas as variáveis envolvidas (internas e externas), bem como uma série de fatores (humano, econômico, etc.), sendo certo que o seu resultado também não poderá ser projetado por meio de simples previsões, mas se dará conforme o contexto envolvido em cada problema enfrentado pelos administradores.

De todo modo, com relação a problemas mais comuns ligados ao cotidiano das organizações, ele também pondera que

[...] muitas decisões nas organizações têm as características da decisão programada e podem, portanto, ser tomadas, pelo menos em parte, através da aplicação sistemática de conceitos encontrados na economia e na contabilidade e de outros métodos quantitativos descritos de vários modos, como, por exemplo, pesquisa operacional ou ciência administrativa. (HAMPTON, 2005, p. 242).

Voltando às diferenças relativas à gestão e ao gerenciamento no que se refere às questões envolvendo resíduos de serviços de saúde, é certo que também foram encontradas grandes diferenças no modo como são tomadas as decisões nas organizações estudadas, assim como com relação à autonomia de cada um dos gerentes para tomar estas referidas decisões.

Com efeito, estas diferenças se tornaram ainda mais acentuadas quando se comparam as organizações pelo critério de sua natureza (pública ou privada), uma vez que, tanto na organização privada (Hospital São Francisco) quanto na fundação (Hospital Sociedade Portuguesa de Beneficência), os gestores possuem autonomia - ainda que parcial - para tomar decisões no que tange ao gerenciamento dos RSS, enquanto que, nas organizações públicas (UBDS Central e Centro de Saúde Escola da Faculdade de Medicina de Ribeirão Preto), os gerentes se limitam a aplicar procedimentos previamente determinados pela própria Secretaria 
Municipal da Saúde, o que os deixa praticamente sem autonomia para tomar qualquer decisão neste aspecto.

Além da natureza de cada organização estudada ou do modo particular como cada uma é administrada, as diferenças no tocante à autonomia de cada um dos seus gestores para tomar decisões envolvendo RSS, também se explicam pelos próprios princípios que norteiam a administração pública. Neste sentido, Meirelles (2007), que explica que a administração pública possui restrições naturais à tomada de decisões, decorrentes da própria hierarquia existente entre os ocupantes de funções públicas dentro dos órgãos públicos, além do próprio formalismo legal e dos princípios que norteiam o direito administrativo.

Para Matias-Pereira (2008), a administração de qualquer órgão, entidade ou autarquia pública, envolvendo tanto a organização de seus serviços, quanto a execução de políticas públicas, pressupõe necessariamente um planejamento ${ }^{36}$ prévio, que esteja de acordo tanto com a legislação existente quanto com os princípios de direito administrativo, além de obedecer estritamente as disposições orçamentárias destinadas àquela entidade. Explica o mencionado autor que:

\begin{abstract}
O Estado tem função explícita de planejamento. O planejamento governamental, portanto, além de um instrumento da ação pública, deve ser visto como uma imposição constitucional. Isso está explícito na Constituição Federal de 1988, por meio de vários dispositivos, que lhe conferem caráter imperativo, ao estabelecer a obrigatoriedade de formulação de planos, de forma ordenada e seqüencial, para viabilizar o alcance dos objetivos previamente estabelecidos, que buscam o atingimento do progresso econômico e social. (MATIAS-PEREIRA, 2008, p. 80-81).
\end{abstract}

Desta forma, em órgãos, autarquias ou repartições públicas, não poderá ser tomada por quem quer que seja nenhuma decisão que esteja em desconformidade com o planejamento prévio realizado pela administração pública direta ou indireta à qual esta entidade esteja subordinada.

Realizadas estas necessárias considerações, é certo que a pesquisa realizada indicou que, na UBDS Central, todas as decisões envolvendo o gerenciamento de resíduos (práticas e procedimentos operacionais, o que fazer e como fazer) não passam pela gerente geral da unidade e muito menos por qualquer outro funcionário daquele posto de saúde, sendo todas centralizadas na Secretaria Municipal da Saúde, na pessoa da gerente de resíduos, a enfermeira-chefe Dra.

\footnotetext{
${ }^{36}$ É extremamente interessante perceber que, entre os teóricos da learning organization, o planejamento é um processo de aprendizagem que permite o afloramento e o questionamento dos modelos mentais dos agentes tendo em vista a possibilidade de uma visão compartilhada. (RIVERA, 2003, p. 247).
} 
Marlene Duarte Mendes, a qual deixou claro que a gestão de RSS da Prefeitura Municipal se baseia, com poucas exceções, na cartilha da ANVISA (RDC 306/04).

Do mesmo modo, todas as decisões envolvendo o gerenciamento de RSS do Centro de Saúde Escola da Faculdade de Medicina de Ribeirão Preto, mesmo relevadas suas particularidades perante as demais unidades de saúde municipais e considerado o fato de possuir, ao contrário do que acontece com a UBDS Central, uma funcionária específica para gerenciar os resíduos da instituição (a enfermeira Luzia Márcia R. Passos, vinculada profissionalmente à USP), provêm da Secretaria Municipal da Saúde de Ribeirão Preto.

Assim, não existe autonomia alguma para a tomada de decisões envolvendo o gerenciamento de resíduos em ambas as unidades públicas estudadas (destacando-se mais uma vez o fato da enfermeira responsável no Centro de Saúde Escola ter inclusive ressaltado em sua entrevista que o que ela pratica ali é o gerenciamento dos RSS, ficando a gestão a cargo da Secretaria Municipal), o que, de certo modo, retira a responsabilidade destas gestoras e dos demais funcionários envolvidos com resíduos, caso seja adotado algum procedimento contrário à legislação em vigor ou adotada uma determinada postura que não se mostre viável ou passível de operacionalização, quando se deparem com conflitos normativos.

Com efeito, nas organizações particulares estudadas, verificou-se exatamente o inverso, ou seja, além de existirem os gestores voltados exclusivamente para a questão dos RSS, os mesmos possuem plena autonomia, em conjunto com órgãos colegiados ou com a direção do hospital, para a tomada de decisões envolvendo tais resíduos, caracterizando assim a prática tanto da gestão quanto do gerenciamento dentro de suas funções diárias dentro destas unidades, ou seja, o pleno exercício da administração (combinando-se teoria com a prática).

O fato de terem autonomia para decidir sobre rumos, metas, diretrizes, procedimentos e processos operacionais envolvendo os resíduos de serviço de saúde em suas organizações, não torna tais gestores imunes a conflitos normativos ou aplicação de normas de difícil operacionalização; pelo contrário, os tornam mais responsáveis com suas ações, o que deixa a adoção de qualquer ação passível de análise mais apurada e, via de regra, ouvindo-se todos os funcionários do setor ou seus representantes, inclusive de empresas terceirizadas. Não é por acaso que, tanto na organização particular quanto na fundação, foi constatada a existência de Comissão Interna de Prevenção de Acidentes (CIPA), Setor de Segurança do Trabalho, CCIH, DMST e 
outros, ao contrário das organizações públicas, onde praticamente não existem órgãos colegiados ou de representação dentro de suas unidades.

No Hospital São Francisco, a gestão de resíduos fica a cargo da Sra. Sonia Maria Ferreira Marcelino Riccio, gerente de enfermagem, a qual, quando se depara com conflitos normativos ou dúvidas sobre aplicação de normas, tem plena autonomia para dar a palavra final relativamente às decisões sobre a aplicação dos procedimentos que entender mais adequados, após ouvir e se reunir com uma equipe multidisciplinar do próprio hospital, composta por membros do departamento jurídico interno, do SESMT, da CIPA, por enfermeiros e auxiliares de enfermagem. Apesar de dar a palavra final, a opinião de todos é considerada, assim como as idéias e sugestões passadas por cada empregado, os quais acabam participando assim, ainda que de maneira indireta ou parcial, do processo de tomada de decisões (o qual não sofre nenhuma influência da direção geral da organização, numa autêntica demonstração de delegação de poderes e responsabilidades ao setor pertinente).

Destaque-se que, em qualquer tipo de organização, a competência dos colaboradores "é a base para o sucesso de suas atividades e para a eficiência e a eficácia de seus processos de negócios, além de apoiar sua estratégia organizacional e de gerar vantagem competitiva sustentável” (ROSSATTO, 2002, p. 157).

Por sua vez, na Sociedade Portuguesa de Beneficência, de acordo com informações do Sr. Jamiro Marques da Cruz, técnico em segurança do trabalho e chefe do setor de resíduos, todas as decisões que envolvam conflitos normativos ou dúvidas sobre aplicações de normas em casos concretos de operacionalização de resíduos são tomadas ouvindo-se os representantes da CIPA, do COE (Comitê de Organização de Eventos), os enfermeiros e auxiliares de enfermagem (através da realização de reuniões) e o próprio pessoal da limpeza. Persistindo dúvidas, todas elas, bem como as idéias ouvidas e sugestões formuladas são levadas à diretoria geral do hospital, que concede ao Sr. Jamiro total discricionaridade para, após consideradas as opiniões gerais dos diversos setores e departamentos envolvidos, dar a palavra final e, assim, adotar os procedimentos que considerar mais adequados.

Para concluir, já consideradas as particularidades deste caso do estudo, Chiavenato (v. 2, 2002) entende que o processo de tomada de decisões não envolve apenas a resolução de problemas que surgem ou que possam surgir no seio de uma organização, e muito menos que sejam levados em conta apenas os aspectos formais, deixando de lado os fatores interpessoais 
envolvidos, sendo verdadeiramente importantes, para qualquer decisão, a criação e a inovação que mirem no futuro criando condições de prevenir conflitos e evitar opções equivocadas, o que somente pode ser conseguido, em qualquer organização, com a participação de todos os seus stakeholders. 


\section{CONCLUSÃO}

Resíduos de serviços de saúde (RSS), como já exposto, não são aqueles produzidos exclusivamente por hospitais, mas também por clínicas médicas, odontológicas e veterinárias, laboratórios, necrotérios, funerárias, centros de medicina legal, instituições de ensino e pesquisa médica, serviços de acupuntura e tatuagem, dentre outros similares, englobando assim tudo o que representa ou possa representar risco à saúde pública e ao meio ambiente em geral. Daí se extrai a importância de que seja feito seu correto manejo.

E a melhor forma de se manejar corretamente os RSS é através do seu gerenciamento seja ele interno (envolvendo todos os procedimentos adotados dentro da organização que os produziu) ou externo (abrangendo todo o processo que se passa fora da entidade geradora, até sua derradeira destinação final) - gerenciamento este que deverá sempre visar a minimização da produção destes resíduos e, com relação aqueles que foram gerados, o seu encaminhamento seguro e eficiente, objetivando assim a preservação da vida, animal e humana (incluindo aí não só os profissionais da própria organização de saúde, mas também e principalmente, de toda a coletividade que existe em seu entorno).

Tamanha importância que tem o tema também serve para demonstrar a sua interdisciplinaridade, eis que envolve tanto conceitos pertencentes a universos mais complexos (como, por exemplo, da gestão ambiental e da administração das organizações), quanto princípios do saber mais específicos (tais como os que se referem à saúde pública e ao gerenciamento hospitalar ou de resíduos sólidos). Portanto, qualquer pesquisa que envolva casos concretos de gerenciamento de RSS interessa ou deve interessar, em tese, a vários campos científicos distintos, das ciências biológicas às ciências humanas e sociais aplicadas.

Desta forma, após a realização da pesquisa nos exatos moldes que foram propostos, foram encontradas diferenças no gerenciamento dos RSS nas quatro instituições estudadas. Estas diferenças começaram na existência ou não de um Plano de Gerenciamento de Resíduos PGRSS (cuja implementação não fora constatada em todas as organizações) e se propagaram quando analisados fatores como o: grau de conhecimento legislativo e normativo dos administradores; o modo como são tomadas as decisões referentes a resíduos (existem entidades onde se pratica tanto a gestão como o gerenciamento dos mesmos e outras que se reduzem apenas a este último procedimento) e a infra-estrutura de cada organização em particular. 
Genericamente, pode-se dizer que as diferenças encontradas nas organizações pesquisadas não estão ligadas nem com o modo como os responsáveis pela tomada de decisões interpretam as normas existentes, e nem com uma hipotética escolha, dentre vários, de um dado dispositivo legal que seja mais viável operacionalmente.

$\mathrm{Na}$ verdade, o que foi constatado é que as diferenças nas práticas de gerenciamento nos casos do estudo ocorrem por causa da própria natureza das organizações pesquisadas, devendo-se considerar, para tanto, as características inatas dos dois macro-universos às quais as mesmas podem pertencer, quais sejam: o da administração pública (com todo o seu formalismo e rigidez) ou o da administração privada (com toda a flexibilidade exigida pela moderna ciência da administração).

A proposição acima encontra seu fundamento, principalmente, em duas premissas básicas que restaram expostas no trabalho: a questão da fiscalização e a maneira como são tomadas as decisões nas organizações pesquisadas.

Com relação à fiscalização, é certo que mesmo que de maneira rara ou eventual, a organização privada, assim como a fundação, estando (ainda que em teoria) sujeitas a todo o tipo de fiscalização por parte de entidades da administração pública direta ou indireta que possuam algum interesse regulatório sobre suas atividades, encontram-se muito mais suscetíveis a conflitos normativos - por exemplo, adotando um procedimento de acordo com a norma de um órgão mas em desacordo com a de outro órgão - como de fato já ocorreu, conforme relatos dos gestores - do que os seus pares de natureza pública municipal ou mista (Estado, Município e Autarquias). Neste sentido, é certo que ambas as unidades públicas são controladas exclusivamente pelo próprio poder público municipal, no exercício da auto-fiscalização.

No tocante à questão da autonomia, os administradores das organizações privadas, por praticarem tanto a gestão quanto o gerenciamento, encontram-se muito mais propensos a verem suas decisões contestadas por órgãos ou entidades ambientais do que seus colegas da rede pública, os quais se limitam a aplicar processos e procedimentos que já vêm previamente decididos e determinados pela Secretaria Municipal da Saúde, podendo assim se eximir de qualquer responsabilidade no caso de um eventual conflito normativo. 
Isso não quer dizer, pura e simplesmente, que unidades públicas não se deparem com conflitos normativos ou que não estejam sujeitas a eles. Referidos conflitos existem ${ }^{37}$, independentemente da natureza da organização de saúde em questão, como, por exemplo, os que foram levantados ou mencionados nas entrevistas, referentes a vários dispositivos da RDC 306/2004 da ANVISA e das resoluções 05/1993 e 283/2001 do CONAMA, no tocante à classificação dos RSS por grupos, lixeiras, transporte interno, etc. O que se constatou é que estas organizações públicas encontram-se menos sujeitas a se depararem com este tipo de conflito do que seus pares de natureza particular, seja por causa da auto-fiscalização, seja por causa da falta de autonomia de seus gerentes envolvendo tomada de decisões.

Lado outro, ainda que as organizações privadas fossem fiscalizadas, de maneira exclusiva, apenas pela Prefeitura Municipal de Ribeirão Preto, seus gestores continuariam em franca desvantagem frente aos gerentes públicos, pelo simples fato de o poder público municipal exigir das entidades particulares o cumprimento imediato de todas as normas da cartilha da ANVISA, ao mesmo tempo em que as suas próprias unidades de saúde não a cumprem integralmente, notadamente no que diz respeito à infra-estrutura exigida, aquisição de materiais e equipamentos específicos e adequação de pessoal, construções ou espaços.

Provavelmente por este motivo é que tenham sido encontradas diferenças estruturais tão díspares entre as instalações das organizações objeto do estudo, como, por exemplo, com relação às lixeiras basculantes com tampa de pedal (presentes nas unidades privadas e ausentes nas públicas), corredores ou rotas de transporte interno de RSS pré-definidas em locais e horários com menor fluxo de pessoas (presentes nas unidades privadas e ausentes nas públicas) e equipamentos de tratamento, como autoclaves e microondas (presentes nas unidades privadas e ausentes nas públicas).

Assim, tem-se que o administrador hospitalar privado tem uma preocupação maior, eis que ao participar diretamente da gestão, precisa pensar na alocação de recursos, disponibilização de pessoal e aquisição de equipamentos para cumprir com todas as leis e normas emanadas por diferentes órgãos, sujeitando-se sempre, como no adágio popular, a agradar a uns desagradando a outros, enquanto que a tarefa dos gerentes dos casos de estudo de natureza pública é mais

\footnotetext{
${ }^{37}$ Os conflitos normativos mais lembrados pelo pessoal entrevistado foram mesmo entre a ANVISA e o CONAMA, apesar da gerente de resíduos da Secretaria Municipal da Saúde destacar que, no caso das lixeiras basculantes com tampa e pedal, também há conflito entre o CONAMA, a CETESB/SP e a Vigilância Sanitária do Estado de São Paulo. No mais, eventuais conflitos entre a legislação federal, estadual e municipal foram também pouco levantados.
} 
simples, limitando-se à aplicação de procedimentos previamente definidos, sem participação na sua escolha. E ainda que a discricionariedade dos gerentes das organizações públicas estudadas fosse maior, suas atribuições seriam igualmente limitadas, por causa dos próprios princípios formais que norteiam a administração pública. Nesta linha de raciocínio, qualquer decisão envolvendo alocação de recursos para aquisição de novo equipamento, por exemplo, deveria, antes de tudo, se ater ao orçamento básico do órgão, previamente entabulado por lei.

De todo modo, não pairam dúvidas de que, independentemente da natureza da organização, qualquer administrador, seja ele um gestor no sentido lato ou um gerente no sentido stricto, deve pautar sua conduta em respeito às normas existentes, notadamente aquelas que regulamentam suas atividades. Isso se torna ainda mais verdadeiro quando seu trabalho diário se relaciona com qualquer matéria de natureza ambiental, pois qualquer deslize pode acarretar: revogação de sua licença, imposição de TAC's, aplicação de multas e de outras sanções administrativas, dentre outras punições; podendo culminar, inclusive, com processos judiciais civis e criminais.

Daí a convergência de todas as constatações da presente pesquisa no campo da administração, para aquilo que defendem alguns dos maiores estudiosos brasileiros da área do meio ambiente, no campo jurídico: que a codificação ou compilação de todas as normas de caráter ambiental (Milaré, 1998) hoje existentes (com a conseqüente supressão de algumas delas), na forma de um único diploma legal, serviria não só para solucionar problemas de conflito normativo, mas facilitaria por demais as atividades desempenhadas pelos administradores das organizações envolvidas, bem como o próprio acesso ao conhecimento normativo por parte de todos os cidadãos. Neste sentido, Oliveira (1997), para quem a falta de um verdadeiro "Código Ambiental", no Brasil, ocasiona uma série de problemas (inclusive de atribuições de competência) em questões de matéria ambiental, algumas delas cuja atualidade, complexidade e gravidade é latente nos tempos atuais.

Afinal, qualquer medida que facilite o desempenho operacional de uma organização, cujas atividades, direta ou indiretamente, podem afetar a saúde pública, seria, como de fato é, muito bem vinda, uma vez que iniciativas que garantam uma sociedade sustentável e ambientalmente sadia e equilibrada (SACHS, 1993), deverão se consistir num dos principais objetivos do mundo moderno. 


\section{REFERÊNCIAS BIBLIOGRÁFICAS}

ABNT - Associação Brasileira de Normas Técnicas. NBR - 7.500: Identificação para o Transporte Terrestre, Manuseio, Movimentação e Armazenamento de Produtos. Rio de Janeiro, 2002.

ABNT - Associação Brasileira de Normas Técnicas. NBR - 10.004: Resíduos Sólidos classificação. Rio de Janeiro, 1987 (elaboração) 2004 (revisão).

ABNT - Associação Brasileira de Normas Técnicas. NBR - 10.005: Lixiviação de Resíduos procedimento. Rio de Janeiro, 1987 (elaboração) 2004 (revisão).

ABNT - Associação Brasileira de Normas Técnicas. NBR - 10.006: Solubilização de Resíduos procedimento. Rio de Janeiro, 1987 (elaboração) 2004 (revisão).

ABNT - Associação Brasileira de Normas Técnicas. NBR - 10.007: Amostragem de Resíduos procedimentos. Rio de Janeiro, 1987 (elaboração) 2004 (revisão).

ABNT - Associação Brasileira de Normas Técnicas. NBR - 12.807: Coleta de Resíduos de Serviços de Saúde. Rio de Janeiro, 1993.

ABNT - Associação Brasileira de Normas Técnicas. NBR - 12.808: Resíduos de Serviços de Saúde - classificação. Rio de Janeiro, 1993.

ABNT - Associação Brasileira de Normas Técnicas. NBR - 12.809: Manuseio de Resíduos de Serviços de Saúde - procedimentos. Rio de Janeiro, 1993.

ABNT - Associação Brasileira de Normas Técnicas. NBR - 12.810: Coleta de Resíduos de Serviços de Saúde - procedimentos. Rio de Janeiro, 1993.

AGUIAR, Edson Martins de; FERRAZ, Antonio C. Pinto; SCHALCH, Valdir. Custo do Transporte de Lixo: a influência da morfologia da cidade. Artigo publicado na Revista de Transporte e Tecnologia, Ano IV, $\mathrm{n}^{\mathrm{o}}$ 08. Departamento de Engenharia Civil, Centro de Ciências e Tecnologia da Universidade Federal da Paraíba. Imprenta: Campina Grande-PB, Janeiro/1992.

AKAOUI, Fernando Reverendo Vidal. Compromisso de Ajustamento de Conduta Ambiental. 2. ed. São Paulo: Editora Revista dos Tribunais, 2008.

ANVISA - Agência Nacional de Vigilância Sanitária. Resolução 33/03 da ANVISA. Dispõe sobre o regulamento técnico para o gerenciamento de resíduos de serviços de saúde. Diário Oficial da República Federativa do Brasil. Brasília-DF, 2003.

ANVISA - Agência Nacional de Vigilância Sanitária. Resolução 306/04 da ANVISA. Dispõe sobre o regulamento técnico para o gerenciamento de resíduos de serviços de saúde. Diário Oficial da República Federativa do Brasil. Brasília-DF, 2004. 
Benjamin, Antonio Herman V. A Proteção do Meio Ambiente nos Países Menos

Desenvolvidos: o caso da América Latina. Revista de Direito Ambiental n ${ }^{\circ} 0$. São Paulo: Editora Revista dos Tribunais, 1995.

BOSI, Maria Lúcia Magalhães; MERCADO, Francisco Javier (Org.). Pesquisa Qualitativa de Serviços de Saúde. Petrópolis-RJ: Vozes, 2004.

BOTAZZO, Carlos. Unidade Básica de Saúde: a porta do sistema revisitada. Bauru-SP: EDUSC, 1999 (Coleção Saúde e Sociedade).

BRASIL. Constituição da República Federativa do Brasil: promulgada em 05 de outubro de 1988. Obra coletiva de autoria da Editora Saraiva com a colaboração de Antonio Luiz de Toledo Pinto, Márcia Cristina Vaz dos Santos Windt e Luiz Eduardo Alves de Siqueira. 24. ed. São Paulo: Saraiva, 2000 (Coleção Saraiva de Legislação).

BRASIL. MINISTÉRIO DO TRABALHO E EMPREGO. Portaria n ${ }^{\circ}$ 485/05 do Ministério do Trabalho e Emprego. Aprova a Norma Regulamentadora no 32 (NR 32) (Segurança e Saúde no Trabalho em Estabelecimentos de Saúde). Diário Oficial da República Federativa do Brasil. Brasília-DF, 2005.

BRASIL, PRESIDÊNCIA DA REPÚBLICA. Subchefia para Assuntos Jurídicos. Lei $n^{\circ} 5.318$, de 26.09.1967. Institui a Política Nacional de Saneamento e cria o Conselho Nacional de

Saneamento. Diário Oficial da República Federativa do Brasil. Brasília-DF, 1967.

BRASIL. PRESIDÊNCIA DA REPÚBLICA. Subchefia para Assuntos Jurídicos. Lei n 6.938 de 31.08.1981. Dispõe sobre a Política Nacional do Meio Ambiente, seus fins e mecanismos de formulação e aplicação, e dá outras providências. Diário Oficial da República Federativa do Brasil. Brasília-DF, 1981.

BRASIL. PRESIDÊNCIA DA REPÚBLICA. Subchefia para Assuntos Jurídicos. Lei no 8.666 de 21.06.1993. Regulamenta o art. 37, inciso XXI, da Constituição Federal, institui normas para licitações e contratos da Administração Pública e dá outras providências. Diário Oficial da República Federativa do Brasil. Brasília-DF, 1993.

BRASIL. PRESIDÊNCIA DA REPÚBLICA. Subchefia para Assuntos Jurídicos. Lei no 8.987 de 13.02.1995. Dispõe sobre o regime de concessão e permissão da prestação de serviços públicos previsto no art. 175 da Constituição Federal, e dá outras providências. Diário Oficial da República Federativa do Brasil. Brasília-DF, 1995.

BRASIL, PRESIDÊNCIA DA REPÚBLICA. Subchefia para Assuntos Jurídicos. Lei no 11.079 de 31.12.2004. Institui as normas gerais para licitação e contratação de parceria público-privada no âmbito da administração pública. Diário Oficial da República Federativa do Brasil. Brasília-DF, 2004.

BRUNA, Gilda Collet; PHILIPPI Jr., Arlindo; ROMERO, Marcelo de Andrade. Curso de Gestão Ambiental. São Paulo: Manole, 2004. 
CHIAVENATO, Idalberto. Teoria Geral da Administração. Volume 1. 6. ed. Rio de Janeiro: Elsevier, 2001.

Teoria Geral da Administração. Volume 2. 6. ed. Rio de Janeiro: Elsevier, 2002.

COMPARATO, Fábio Konder. A Afirmação Histórica dos Direitos Humanos. 3. ed. São Paulo: Saraiva, 2003.

CONAMA - CONSELHO NACIONAL DO MEIO AMBIENTE. Brasil. Resolução 05/93 do CONAMA. Define os procedimentos básicos relativos ao gerenciamento de resíduos sólidos de serviços de saúde. Diário Oficial da República Federativa do Brasil. Brasília-DF, 1993.

CONAMA - CONSELHO NACIONAL DO MEIO AMBIENTE. Brasil. Resolução 283/01 do CONAMA. Define sobre o tratamento e destinação final dos resíduos sólidos. Diário Oficial da República Federativa do Brasil. Brasília-DF, 2001.

CONAMA - Conselho Nacional do Meio Ambiente. Brasil. Resolução 307/02 do CONAMA. Estabelece diretrizes, critérios e procedimentos para a gestão dos resíduos da construção civil. Diário Oficial da República Federativa do Brasil. Brasília-DF, 2002.

CONAMA - Conselho Nacional do Meio Ambiente. Brasil. Resolução 313/02 do CONAMA. Dispõe sobre o inventário nacional de resíduos sólidos industriais. Diário Oficial da República Federativa do Brasil. Brasília-DF, 2002.

CONAMA - Conselho Nacional do Meio Ambiente. Brasil. Resolução 358/05 do CONAMA. Dispõe sobre o tratamento e a disposição final dos resíduos dos serviços de saúde e dá outras providências. Diário Oficial da República Federativa do Brasil. Brasília-DF, 2005.

DERANI, Cristiane. Direito Ambiental Econômico. 3. ed. São Paulo: Saraiva, 2008.

DERISIO, José Carlos. Introdução ao Controle de Poluição Ambiental. CETESB Companhia de Tecnologia de Saneamento Ambiental, São Paulo: 1992.

DIAS, Reinaldo. Gestão Ambiental: responsabilidade social e sustentabilidade. São Paulo: Atlas, 2006.

FARIAS, Talden. Licenciamento Ambiental: aspectos teóricos e práticos. Belo Horizonte: Fórum, 2007.

FIORILLO, Celso Antonio Pacheco. Curso de Direito Ambiental Brasileiro. 9. ed. São Paulo: Saraiva, 2008.

GUIMARÃES, Bruno Folly; PROCHNIK, Victor. Sete Desafios para uma Implantação do Balanced Scorecard em Hospitais (Capítulo do livro BSC em Organizações da Saúde). Artigo aceito para apresentação na $3 r d$ Conference on Performance Measurement and Management Control - Improving Organizations and Society. Nice - França, 22.03.2005. 
HAMPTON, David. R. Tradutores: Lauro Santos Blandy; Antonio C. Amaru Maximiano. Administração Contemporânea: teoria, prática e casos. 3. ed. São Paulo: Pearson Makron Books, 2005.

HOSPITAL SÃO FRANCISCO. Disponível em: <http://www.saofrancisco.com.br>. Acesso em: 28 ago. 2008.

INSTITUTO BRASILEIRO DE DEFESA DO CONSUMIDOR - IDEC. Disponível em: $<$ http://www.idec.org.br>. Acesso em: 15 maio 2008.

JACOBI, Pedro (Organizador). Gestão Compartilhada dos Resíduos Sólidos no Brasil: inovação com inclusão social. São Paulo: Annablume, 2006.

LIMA, Carlos Alberto Nogueira. Administração Pública: teoria e mais de 400 questões. 3. ed. Rio de Janeiro: Elsevier, 2006.

MARTINS, Domingos dos Santos. Custeio Hospitalar por Atividades: activity based costing. São Paulo: Atlas, 2002.

MATIAS-PEREIRA, José. Manual de Gestão Pública Contemporânea. 3. reimp. São Paulo: Atlas, 2008.

MAXIMIANO, Antonio César Amaru. Teoria Geral da Administração: da revolução urbana à revolução digital. 4. ed. São Paulo: Atlas, 2004.

MEIRELLES, Hely Lopes. Direito Administrativo Brasileiro. 33. ed. São Paulo: Malheiros, 2007.

MILARÉ, Edis. Direito do Ambiente: um direito adulto. Revista de Direito Ambiental n 15. São Paulo: Editora Revista dos Tribunais, Julho-Setembro 1999.

. Por Um Reordenamento Jurídico-Ambiental. Revista de Direito Ambiental n 09. São Paulo: Editora Revista dos Tribunais, Janeiro-Março 1998.

MORAES, Luís Carlos Silva de. Curso de Direito Ambiental. São Paulo: Atlas, 2001.

MOREIRA, Maria Suely. Estratégia e Implantação do Sistema de Gestão Ambiental (Modelo ISO 14000). São Paulo: EDG, 2001.

NASCIMENTO, Luís Felipe; LEMOS, Ângela Denise da Cunha; MELLO, Maria Celina Abreu de. Gestão Socioambiental Estratégica. Porto Alegre-RS: Bookman, 2008.

NOGUEIRA, Sandro D'Amato. Resumo de Direito Ambiental. Leme-SP: BH Editora, 2008.

OLIVEIRA, Sulivan Silvestre. A Necessidade de Codificação das Leis Ambientais no Brasil como Forma de Garantir a Eficaz Proteção Ambiental do Cidadão. Revista de Direito

Ambiental, n. 07, São Paulo, Editora Revista dos Tribunais, Julho-Setembro 1997. 
ONCALA, Andréa Arean. PPPs no Brasil. Revista Conexão Migalhas. Campinas-SP: Millennium Editora Ltda., 2006.

PARRA FILHO, Domingos. SANTOS, João Almeida. Apresentação de Trabalhos Científicos: monografia, TCC, teses e dissertações. 3. ed. São Paulo: Futura, 2000.

PHILIPPI JR., Arlindo (Editor). Saneamento, Saúde e Ambiente: fundamentos para um desenvolvimento sustentável. Barueri-SP: Manole, 2005.

. Curso de Gestão Ambiental. Barueri-SP: Manole, 2004 (reimpresso em 2006).

POLTRONIERI, Renato. Parcerias Público-Privadas e a Atuação Administrativa: reflexões sobre a instituição de parcerias entre a administração pública e o setor privado e os contratos administrativos aplicáveis a esta forma especial de concessão de serviço público. São Paulo: Editora Juarez de Oliveira, 2005.

PREFEITURA MUNICIPAL DE RIBEIRÃO PRETO. Secretaria da Saúde. Disponível em: $<$ http://www.saude.ribeiraopreto.sp.gov.br/ssaude/>. Acesso em: 31 ago. 2008.

RIBAS, Luiz César. Os Processos de Gestão Ambiental, de Avaliação Ambiental e de Mensuração de Danos Ambientais - Escopo Conceitual. Revista de Direito Ambiental, n. 08. Editora Revista dos Tribunais, out./dez. 1997.

RIBEIRÃO PRETO. Lei Complementar no 847 de 29.03.1999. Institui a taxa de coleta, transporte, tratamento e destinação final de resíduos de serviços de saúde e congêneres. Diário Oficial do Município de Ribeirão Preto. Ribeirão Preto - SP, 1999.

RIBEIRÃO PRETO. Lei Complementar $n^{\circ} 1.790$ de 27.12.2004. Altera a Lei Complementar $n^{\circ}$ 847, de 29.03.1999, que instituiu a taxa de coleta, transporte, tratamento e destinação final de resíduos de serviços de saúde e congêneres. Diário Oficial do Município de Ribeirão Preto. Ribeirão Preto - SP, 2004.

RIVERA, Francisco Javier Uribe. Análise Estratégica em Saúde e Gestão pela Escuta. Rio de Janeiro: Fiocruz, 2003.

ROSSATTO, Maria Antonieta. Gestão do Conhecimento: a busca da humanização, transparência, socialização e valorização do intangível. Rio de Janeiro: Interciência, 2003.

RUIZ, João Álvaro. Metodologia Científica: guia para eficiência nos estudos. 3. ed. São Paulo: Atlas, 1992.

SACHS, Ignacy. Estratégias de Transição para o Século XXI. São Paulo: Studio Nobal Fundap, 1993.

SALAZAR, Andrea. RODRIGUES, Karina Grou. SILVER, Lynn. SCHEFFER, Mário. (Organizadores). O SUS Pode Ser Seu Melhor Plano de Saúde. Artigo publicado no site do 
Idec - Instituto Brasileiro de Defesa do Consumidor. Disponível em www.idec.org.br. Acesso em: 15.05.2008.

SÃO PAULO. Secretaria de Estado do Meio Ambiente. Gabinete do Secretário e Assessorias. Resolução SMA 22, de 16.05.2007. Dispõe sobre a execução do projeto ambiental estratégico "Licenciamento Ambiental Unificado" que visa integrar e unificar o licenciamento ambiental no Estado de São Paulo, altera procedimentos para o licenciamento das atividades que especifica e dá outras providências. Diário Oficial do Estado de São Paulo. São Paulo, 2007a.

SÃO PAULO. Secretaria de Estado do Meio Ambiente. Gabinete do Secretário e Assessorias. Resolução SMA 50, de 13.11.2007. Dispõe sobre o Projeto Ambiental Estratégico Lixo Mínimo e dá providências correlatas. Diário Oficial do Estado de São Paulo. São Paulo, 2007b.

SEIFFERT, Mari Elizabete Bernardini. Gestão Ambiental: instrumentos, esferas de ação e educação ambiental. São Paulo: Atlas, 2007.

SEVERINO, Antônio Joaquim. Metodologia do Trabalho Científico. 23. ed. São Paulo: Cortez Editora, 2007.

SLACK, Nigel; CHAMBERS, Stuart; JOHNSTON, Robert. Administração da Produção. 2. ed. São Paulo: Atlas, 2002.

SOARES, Guido Fernando Silva. Direito Internacional do Meio Ambiente. São Paulo: Atlas, 2001.

SOUZA, Eduardo Luiz de. Medidas para Prevenção e Minimização da Contaminação Ambiental e Humana Causada pelos Resíduos de Serviços de Saúde Gerados em Estabelecimento Hospitalar - Estudo de Caso. 2005. Tese (Doutorado em Ciências da Engenharia Ambiental) - Escola de Engenharia de São Carlos - USP. São Carlos, 2005.

SOUZA, Marcelo Pereira de. Instrumentos de Gestão Ambiental: fundamentos e prática. São Carlos-SP: Editora Riani Costa, 2000.

STEVENSON, William J. Tradutor: Alfredo Alves de Farias. Estatística Aplicada à Administração. São Paulo: Harper \& Row do Brasil, 2001.

SUNDFELD, Carlos Ari (Coord). Parcerias Público-Privadas. São Paulo: Malheiros Editores Ltda. 2005.

SUNG, Jung Mo; SILVA, Josué Cândido da. Conversando sobre Ética e Sociedade. 14. ed. Rio de Janeiro: Vozes, 2007.

TARABOULSI, Fadi Antoine. Administração de Hotelaria Hospitalar: serviços aos clientes, humanização do atendimento, departamentalização, gerenciamento, saúde e turismo e hospitalidade. 2. ed. São Paulo: Atlas, 2004. 
VALLE, Gerson; PARREIRA, Roberto D. M. Instituições de Direito Público e Privado. 3. ed. Rio de Janeiro: Edições Trabalhistas, 1992.

YIN, Robert. K. Estudo de Caso: planejamento e métodos. 2. ed. Porto Alegre-RS: Bookman, 2001 (reimpresso em 2003). 


\section{APÊNDICE A - MODELOS DE QUESTÕES A SEREM UTILIZADAS NA ENTREVISTA}

\section{Roteiro da Entrevista}

As entrevistas, como já exposto nos tópicos do trabalho referentes aos procedimentos metodológicos, seguiram todas um roteiro pré-determinado, sendo certo que as perguntas realizadas variaram conforme o grau hierárquico do entrevistado dentro da organização e as funções que verdadeiramente exercia. Assim, as questões foram divididas (não obstante existirem também perguntas ou dúvidas comuns), entre aquelas que foram aplicadas aos gestores (diretores, supervisores e gerentes) e aquelas que foram direcionadas ao pessoal operacional (auxiliares de enfermagem, técnicos em enfermagem, pessoal da limpeza e profissionais da saúde de um modo geral). Segue na seqüência a estruturação dos dois tipos de entrevistas que foram realizadas:

\section{Perguntas aos Gestores}

1) Qual o percentual total dos resíduos gerados na instituição é considerado RSS?

2) Existe um departamento específico para gerenciar o RSS dentro da organização?

3) Como toma conhecimento da legislação sobre RSS? Acompanha o Diário Oficial ou acessa freqüentemente os sites do Ministério da Saúde, ABNT, ANVISA, CONAMA e outros?

4) Conhece a diferença entre leis, normas, portarias, decretos e resoluções?

5) Está atualizado sobre as normas existentes em âmbito federal, estadual e municipal?

6) Qual sua atitude frente ao conflito normativo?

7) Já teve que tomar decisão sobre procedimentos conflitantes existentes nestas normas? Em caso positivo, explicar quantas vezes isso já ocorreu e detalhar os casos.

8) A legislação de qual órgão ou poder público é comumente seguida ou utilizada dentro da instituição?

9) Enumere algumas facilidades encontradas para cumprir a legislação apontada no item " 06 ".

10) Enumere algumas dificuldades encontradas para cumprir a legislação apontada no item " 06 ".

11) Além dos possíveis entraves legais, a falta de compilação da legislação em um único código acaba por criar também entraves econômicos, operacionais, financeiros, administrativos ou políticos? Exemplifique.

12) Qual sua atitude frente aos procedimentos normativos impraticáveis do ponto de vista operacional ou inviáveis, do ponto de vista econômico? 
13) A infra-estrutura para o gerenciamento de resíduos deste estabelecimento está adequada?

14) Já fez algum curso sobre gestão ou gerenciamento de RSS?

15) Promove treinamentos em seu pessoal, relativamente ao acondicionamento, transporte, tratamento e destino final dos RSS? Em caso positivo, com qual freqüência?

16) Tem algum relacionamento com órgãos fiscalizadores e organizações coletoras de resíduos?

17) Tem algum processo de certificação de qualidade envolvendo resíduos?

\section{Perguntas ao Pessoal do Nível Operacional}

1) Qual percentual do total de resíduos gerados na instituição é considerado infectante?

2) Qual é o destino final destes resíduos?

3) Já fez algum curso específico, a título de RSS? Em caso positivo, este curso foi promovido pela instituição em que trabalha?

4) Tem acesso ao Diário Oficial da União, do Estado ou ao Municipal dentro da instituição em que trabalha? Tem acesso aos sites do Ministério da Saúde, ANVISA, CONAMA, ABNT e outros, dentro do local de trabalho?

5) Existe o hábito da gerência ou da direção em passar circulares ou memorandos para os funcionários que lidam com RSS, atualizando-os sobre novas normas, portarias e resoluções? Em caso positivo, com qual freqüência?

6) Há treinamento, dentro da organização, para o pessoal envolvido com produção, acondicionamento, transporte interno ou com a destinação final dos RSS?

7) Mencione algumas facilidades para o descarte adequado dos RSS (considerando-se todos os tipos).

8) Mencione algumas dificuldades para o descarte adequado dos RSS (considerando-se todos os tipos).

9) Trabalha exclusivamente com RSS ou acumula com alguma outra função?

10) Existem recursos físicos, materiais e de capacitação adequados?

11) Há canal de comunicação entre o gerente de resíduos e os funcionários da área?

12) Os recipientes para RSS (sacos plásticos, caixas, carrinhos, etc.) estão adequados?

13) A sinalização para transporte interno dos RSS é adequada?

14) A infra-estrutura da organização para o fluxo interno dos RSS está adequada?

15) Existe integração entre a CIPA, CCIH e DMST?

16) Conhece o que é o Protocolo para Acidentes com Material Biológico? 
17) Existe Protocolo para Acidentes com Material Biológico? Conhece algum caso em que o mesmo já tenha sido utilizado? Em caso positivo, exemplifique. 